\title{
The classification of the Pterobranchia (Cephalodiscida and Graptolithina)
}

\author{
JÖRG MALETZ
}

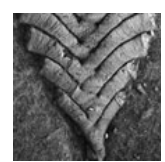

This paper presents a proposal for a taxonomic approach to the classification of the Pterobranchia (Cephalodiscida and Graptolithina) to be adopted for the revision of the Treatise on Invertebrate Paleontology, Part V (Hemichordata), currently in preparation. A combination of traditional Linnaean taxonomy, supported by cladistic analyses in some groups is proposed herein as a practical solution for the classification of the Graptolithina as for many groups a cladistic analysis has never been attempted and is unlikely to be undertaken in the near future. The number of ranked taxa has been kept as low as possible, with all genus level taxa referred to a family. All families and higher taxonomic units are discussed, but new taxa have not been introduced. Paraphyletic (but not polyphyletic) taxa are accepted as useful units in this classification. A number of recently introduced taxonomic units, based on cladistic analyses (e.g. Eugraptoloida, Pan-Reclinata, Pan-Bireclinata), are discussed in the context of this classification and the usefulness of these taxa is critically evaluated. The solution proposed here opts not to name a number of nodes from the published cladistic analyses that potentially could be named and in some cases have been named - not to inflate the hierarchy of the used taxonomic system. Taxa are kept as close as possible to their original definition and not unnecessarily expanded or restricted. The taxonomy proposed here for the Graptolithina indicates that the extensive use of higher level taxa, e.g. orders for small groups of genera as has been done for many benthic graptolite groups in the past is unnecessary and should be avoided. - Key words: Hemichordata, Pterobranchia, Graptolithina, taxonomy, evolution.

MaletZ, J. 2014. The classification of the Pterobranchia (Cephalodiscida and Graptolithina). Bulletin of Geosciences 89(3), 477-540 (25 figures, 2 tables). Czech Geological Survey, Prague. ISSN 1214-1119. Manuscript received July 1, 2013; accepted in revised form February 5, 2014; published online May 7, 2014; issued June 9, 2014.

Jörg Maletz, Institut für Geologische Wissenschaften, Freie Universität Berlin, Malteserstrasse 74-100, D-12249 Berlin, Germany; yorge@zedat.fu-berlin.de

Graptolites represent one of the most important groups of Palaeozoic fossils for a number of geological applications, most particularly biostratigraphy and biogeography. They are also, if well preserved, beautiful and complex fossils and can be used to document and understand evolutionary patterns. For all graptolite studies and applications, a precise and workable taxonomy is essential. During the last half century, the two Treatise editions (Bulman 1955, 1970) have been the standard for all taxonomic work on graptolites, but these are now outdated and a revision is necessary. New insight gained over more than 40 years has to be integrated.

In recent years, cladistic approaches to the interpretation of general taxonomy and of phylogenetic relationships have taken over the field almost entirely with the naming convention introduced as the PhyloCode (latest version: Cantino \& de Queiroz 2010) aimed at revolutionizing naming procedures. PhyloCode is a nomenclatorial concept intended to be applied to naming clades, and only clades, above the species level and used parallel to the concurrent rank-based codes (PhyloCode 4c, Preamble). Interpreta- tions of clades in cladistics are stable by their definition and its link to a specific cladistic diagram (PhyloCode; Cantino \& de Queiroz 2010). A different cladogram (a different hypothesis) involving an identical list of taxa would require completely different names (see discussion in Kojima 2003). In the Linnaean System, taxa are not defined, but are labels for communication (Kojima 2003) and, therefore, are flexible. Over the years, a duality has been established and available taxonomic concepts for graptolites are difficult to conjoin.

One of the main problems for palaeontologists in dealing with taxonomy is the lack of information at all levels (see Padian et al. 1994). Our fossils are poor representations of ancient life and provide very little evidence for any taxonomic interpretation (Fig. 1A, C, D). For example, the soft tissue of the graptolite zooids is barely preserved in the fossil record and we have to work with the secreted housing construction only. Crowther \& Rickards (1977) introduced the currently accepted interpretation of the graptolite colony with its inhabiting zooids (Fig. 1B). In this interpretation the zooids are based on the extant pterobranch 


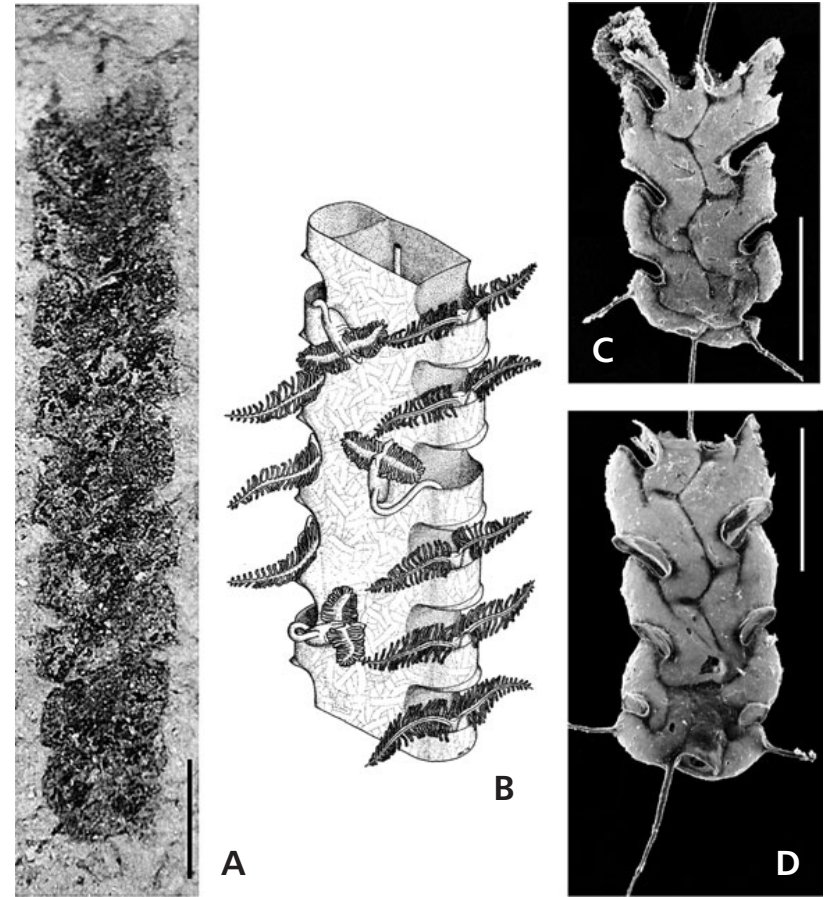

Figure 1. Various axonophoran specimens showing preservation and availability of taxonomically important details. - A - NMV P 31933 holotype of Archiclimacograptus modicellus, flattened and weathered. - B - reconstruction of part of a biserial rhabdosome, based on Crowther \& Rickards (1977, fig. 2). • C, D - Archiclimacograptus sp., Darriwilian, western Newfoundland, SEM images in reverse (C) and obverse (D) views, showing relief specimen for comparison with A. JM 24/01, JM 24/02. Scale bar represents $1 \mathrm{~mm}$.

Rhabdopleura. Recently, Rhabdopleura was identified as a living graptolite (Mitchell et al. 2013), validating the interpretation of Crowther \& Rickards (1977).

The quality of the type material of many graptolite genera may serve as a warning here. Too many genera, especially of dendroid graptolites, are described from fragments and the morphological details of the complete colonies cannot be estimated from these. This is the case also and especially with most of the benthic encrusting taxa described by Kozłowski (1949) and referred to a number of graptolite orders at the time. The material usually consists of small fragments of colonies without preservation of the sicula or any view of the precise shape and development of the colonies.

\section{Graptolite taxonomy through time}

The available morphological information represents the basis for the scientific concept of a taxon, species, genus or other type. Increasing knowledge has invariably resulted in the splitting and introduction of new taxa, the normal procedure in Linnaean taxonomy and an expression of scientific improvement. A single genus, Graptolithus Linnæus,
1758, was enough in the early years of graptolite taxonomy, but obviously is not now. Linnæus (1735, 1768, p. 173) established the genus Graptolithus and thus is responsible for the name that we use for the graptolites. The name was initially intended to describe inorganic markings on rocks and is no longer used as a graptolite genus (see Bulman 1929, p. 170). Bronn (1849, p. 149) referred the graptolites (as the Graptolithina) to the Anthozoa (corals) and included the only available genus, Graptolithus. Here, the graptolites resided for some time. It is the success of Linnaean taxonomy, that the graptolites are not still associated with the corals and that the extant pterobranchs are no longer identified as a strange group of bryozoans ("Polyzoa”) (Sars 1872, M’Intosh 1882).

Graptolite taxonomy progressed with a single family, Graptolitidae (e.g. Hall 1858, 1865; Törnquist 1865; Nicholson 1872a, b), and a small number of genera. Erection of additional genera originally was not deemed necessary and most were introduced only much later, leading to the more than 600 genera now available. Today, more than 275 years after Linnaeus, we understand the graptolites to be a group of pterobranch hemichordates with numerous extinct and a few extant taxa (Mitchell et al. 2010, 2013). We have learned a lot about their evolutionary patterns over more than 500 million years from the Early to Middle Cambrian until today (Maletz 2014).

A number of higher-level taxon names have been introduced over the centuries by various authors, showing the improvement in our taxonomic understanding. Examples of names that today are unfamiliar include the Monophyontes, Mono-Amphiphyontes and Amphiphyontes of Tullberg (1883) (Table 1) and the differentiation of the Axonophora and Axonolipa of Frech (1897). However, Frech's Axonophora is used in modern graptolite taxonomy, re-introduced by Maletz et al. (2009). Some of the early taxonomic concepts show some remarkable insight and a deep understanding of the differentiation of the major groups of graptolites. Even though some of the family level names in Tullberg's (1883) taxonomy may be unfamiliar, their content still makes sense today. The taxonomy and evolutionary understanding of the Graptolithina evolved from the early works of Lapworth (1873a, b, 1879a-d, 1880a-e), Tullberg (1883) and Frech (1897) among others, to the now quite outdated approach in two editions of the Treatise (Bulman 1955, 1970). The general differentiation of the graptolites into a number of families seems to have been the main goal of most early authors. It was an attempt to determine the useful characters to define easily recognizable groups among the Graptolithina and to understand their phylogenetic relationships. Initially, this taxonomic approach was not necessarily based upon the most reliable features, but recognizing this is a modern achievement.

Even though the idea of naming only clades (monophyletic groups) and not grades (polyphyletic groups) is 
Table 1. Early example of classification of the graptolites by Tullberg (1883), including a number of unfamiliar family names.

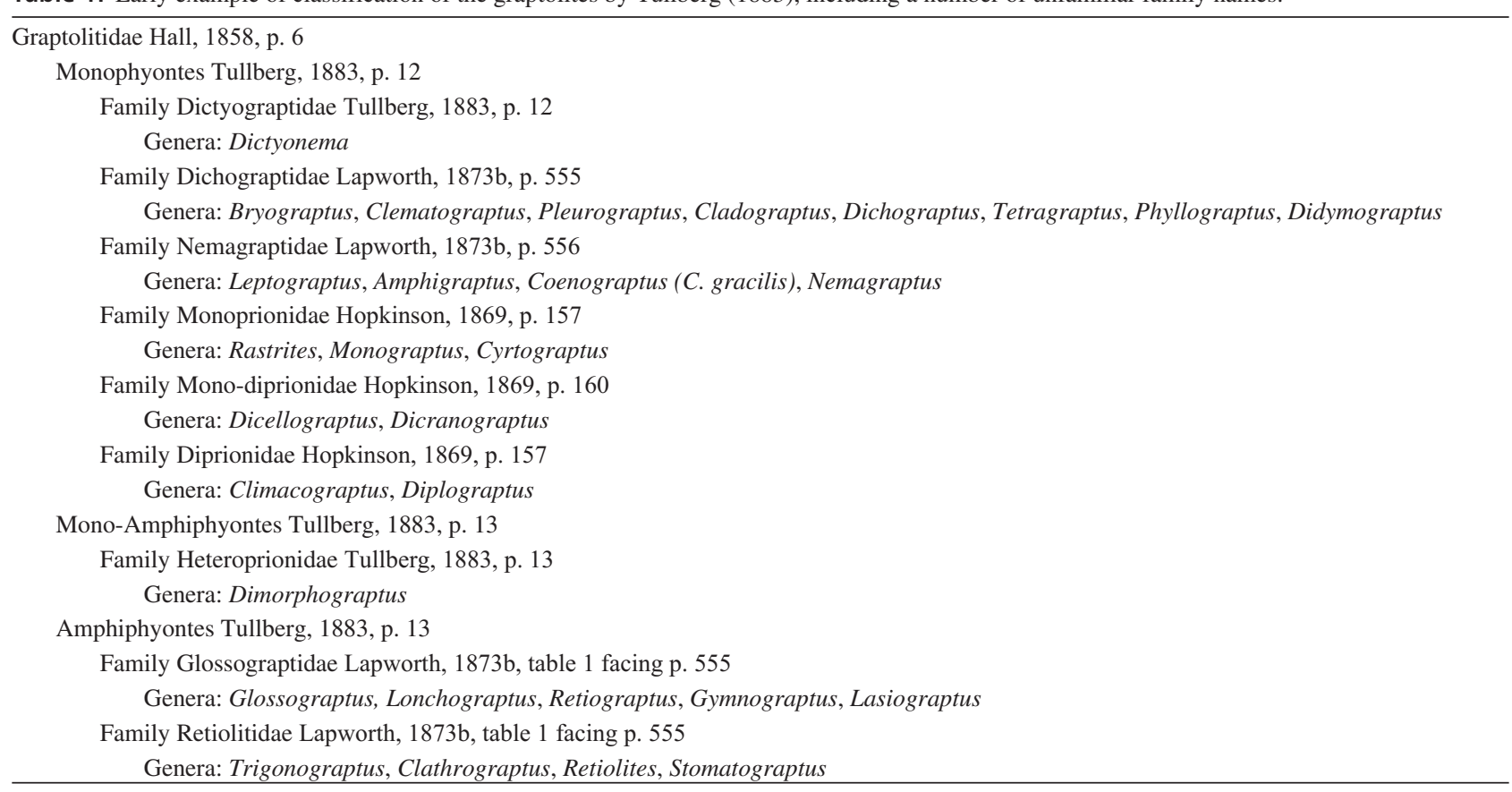

implemented and strongly promoted by cladistics and in the PhyloCode, it is not a new idea (e.g. Haeckel 1866, 1868; Gegenbaur 1870, pp. 78-81). It has been the underlying, even though rarely explicitly stated, aim of every taxonomic approach and every evolutionary interpretation since the introduction of the Linnaean System. Certainly, at the beginning of taxonomic and evolutionary research, knowledge and understanding of synapomorphic characters (a term unknown at the time of Linnæus) was just starting to emerge and taxonomy developed via a "trial-and-error" system, using characters that appeared important and meaningful. This is clearly visible in early graptolite work (e.g. Lapworth 1873b, Tullberg 1883, Gürich 1908), where the number of stipes and uniseriality or biseriality of the stipes were used as the main characters for taxonomic differentiations ( $c f$. Table 1), but see also Yu \& Fang (1979) for a modern example. Many of the graptolite genera described in these taxonomies were soon identified as polyphyletic. This can easily be seen in the statement of Nicholson \& Marr (1895, p. 538), that "the single genus Monograptus may contain descendants of more than one 'family", and Ruedemann (1904, p. 478: "Their results point also to a polyphyletic origin of the large genera of this family and especially of Tetragraptus and Didymograptus") among others. Every specialist on these graptolite taxa would have to agree with the statement of Ruedemann. Jaeger (1978) discussed the trends ("Entwicklungszüge") in the evolution of graptolites following similar ideas, but clearly stated that the trends are descriptional and identical patterns appear often independently in various groups. Thus, he did not emphasize a phylogenetic meaning of these trends.
Over the years a considerable divergence of taxonomic approaches on graptolite classification evolved in various countries (Rigby 1986), resulting from language barriers, differing taxonomic concepts and lack of communication. This division has not yet ended as is seen in several newer approaches (cf. Mu et al. 2002, Mitchell et al. 2007, Maletz et al. 2009). Especially in the western hemisphere, the taxonomy and evolution of the Graptolithina has been hotly debated in recent decades with the increasing popularity of cladistics and the availability of cladistic analyses for a number of groups within the Graptolithina (e.g. Fortey \& Cooper 1986, Mitchell 1987, Bates et al. 2005, Mitchell et al. 2007, Maletz et al. 2009, Melchin et al. 2011, Štorch et al. 2011). This approach has helped us to understand the general relationships of certain groups better, but a complete analysis of all graptolite taxa has not been attempted. The most important results of the cladistic analyses include the recognition of Anisograptidae as ancestors of all planktic graptolites and their inclusion in Graptoloidea (Fortey \& Cooper 1986). Through recognition of the proximal development types of the axonophoran graptolites by Mitchell (1987) and Melchin (1998), a better understanding of many biserial graptolites was achieved. The most recent improvement is the recognition of Rhabdopleura as an extant graptolite (Mitchell et al. 2010, 2013), following a similar, but not identical suggestion by Beklemishev (1951a, 1951b [various later editions in Russian, English and German]) who included the pterobranchs in the class Graptolithoidea.

Of the more than 600 genera of graptolites described, not many are known in enough detail to be useful for any 
phylogenetic analysis, as they often consist of fragmentary material lacking taxonomically relevant details. Therefore, cladistic approaches are still limited to a few well-known groups, such as the retiolitids (Lenz \& Melchin 1997, Bates et al. 2005) and the Ordovician to lower Silurian biserial axonophorans (Mitchell 1987, Mitchell et al. 2007, Melchin et al. 2011, Storch et al. 2011). In these groups, enough taxa are available as isolated or relief specimens, yielding the morphological details necessary for a reasonable cladistic analysis. Even though they represent one of the morphologically and taxonomically most varied groups of graptolites, monograptids have not been subjected to a detailed cladistic analysis, but Muir (1999) provided data for a limited number of Llandovery monograptids.

The resolution of the early Graptolithina is poor in the analysis of Mitchell et al. (2013) and a number of formerly established benthic graptolite orders (e.g. Kozłowski 1949, Bulman 1970, Bates \& Urbanek 2002) have been dissolved. There is no doubt, however, that many of the high level taxonomic units (orders) of Kozłowski (1938, 1949) may be unnecessary and the benthic taxa are in dire need of a modern taxonomic revision.

\section{Systematics}

Ranks are useful and convenient when we want to talk about larger groups of taxa (e.g. genera, species) using a Linnaean taxonomy, but we all know that they represent highly artificial concepts. A family of radiolarians is not comparable to a family of graptolites or any other group of organisms. These ranks are interpretations based on an understanding of taxonomic and evolutionary relationships and represent a simplification based on an evolutionary tree or a cladistic analysis. They evolved over time with the increase of knowledge as we have seen in the example of the family Graptolitidae.

In cladistics, the diagrams represent distributions of characters, analysed step by step, character by character. They reflect general phylogenetic relationships, but do not represent them in detail. Pushing a (named) ranked system upon this analysis could lead to the erection of numerous named and ranked taxa (see Maletz et al. 2009) as potentially every node can be named. Thus, a cladistic system works best without explicit ranking, but every cladistic diagram includes an implicit ranking through the fixed succession of nodes. The arbitrary decision to name only certain nodes on a cladistic diagram ( $c f$. Fig. 2) - and not all nodes - would be an exact equivalent of the "artificial" concept of defined ranks in higher level taxonomic units that exists in a Linnaean System.

It is suggested here to use the Linnaean System approach with the minimum number of taxonomic ranks (Table 2) that is sufficient to express the general relation- ships between the easily recognizable individual groups of graptolites. A system with a higher number of specified ranks may better represent the detailed evolutionary history, but may overburden our taxonomic system with names and being less practical. The extreme pectinate form of the results of the recent cladistic analyses of graptolite taxonomy (Mitchell et al. 2007, Maletz et al. 2009) already led to an increasing number of proposed taxonomic ranks within the Graptolithina, most fully expressed in Maletz et al. (2009). The ranked and named taxa in Maletz et al. (2009), however, show genuine taxonomic relationships and strictly describe monophyletic clades in a stacked succession. These taxa show details of the evolutionary relationships not explicitly stated in the taxonomic system. It is an arbitrary decision to use or not use any of these taxa and to add hierarchical levels or not to the taxonomy.

Monophyly is the central dogma of modern taxonomy (e.g. Hennig 1950, 1965; PhyloCode), but so many previously established taxa have been shown to be paraphyletic or polyphyletic and to make our taxonomic approach a nightmare. Mitchell et al. (2007) and Maletz et al. (2009) largely avoided the problem of paraphyly in graptolites by naming only monophyletic groups and extracting paraphyletic taxa as unnamed stem groups. Whilst there is no doubt that polyphyletic taxa should be avoided at all costs, the question is whether we should abandon all paraphyletic taxa. The discussion is not restricted to fossil taxa. There are several supporters of paraphyly in plant taxonomy for example (Brummitt 1996, 2003; Brummitt \& Sosef 1998; Sosef 1997; Zander 2007; Farjon 2007) and the debate has been quite heated (see Nordal \& Stedje 2005, Ebach et al. 2006). Even though these references refer to botany, not surprisingly, the arguments are the same than the ones used in zoology and show that the same discussion is happening everywhere where taxonomy is used.

The recognition of taxa as monophyletic or paraphyletic is seemingly easy in cladistics. However, the recognition of monophyletic and paraphyletic taxa often rests on the taxonomic resolution of the particular cladistic tree that is produced. Depending upon the number of end-branches in a tree/diagram (resolution), a taxon defined the same way through a synapomorphy-based definition can become monophyletic or paraphyletic in an analysis. The differentiation of Plectograptinae and Retiolitinae may be regarded as a useful example (Fig. 3). These two subfamilies of retiolitids have generally been recognized as separate and easily identifiable (Bouček \& Münch 1952; Lenz \& Melchin 1987, 1997), even though this separation appeared somewhat blurred in a more recent analysis (Bates et al. 2005). Its separation was based mainly on the recognition of a single character, the pustulose surface of the bandages in the Plectograptinae. In this case, the pustulose surface 
Table 2. Proposed classification of the Pterobranchia.

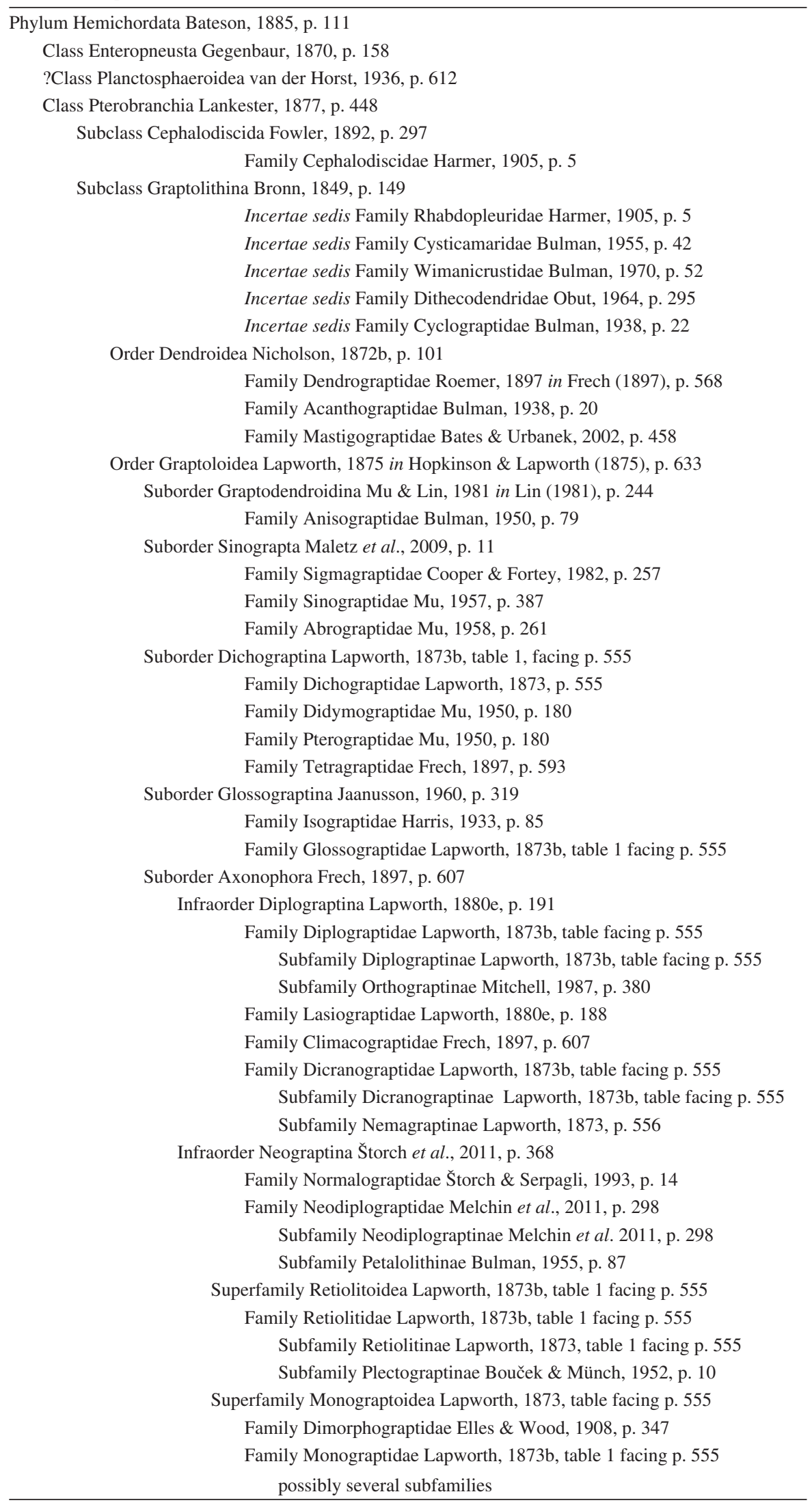


texture is a synapomorphy of Plectograptinae. If only a single genus taxon of Retiolitinae and Plectograptinae is used in an analysis, both would end up as monophyletic sister groups (Fig. 3A).

A different scenario, in which several other retiolitid taxa are added to provide a higher resolution of the analysis (Fig. 3B), shows Retiolitidae as a paraphyletic taxon from which the derived Plectograptinae originate as a monophyletic taxon. The alternative would be to define an [informal] paraphyletic stem group that includes the group formerly called Retiolitinae and separate the derived Plectograptinae from these. Lenz \& Melchin (1997) took a slightly different route and regarded Pseudoretiolites as a paraphyletic stem group and recognized two monophyletic subfamilies, the Retiolitinae and Plectograptinae. A similar "trick" was used by Maletz et al. (2009) for several groups of early Graptoloidea, by routinely identifying informal, paraphyletic stem groups of formally defined monophyletic taxa.

Cannon et al. (2009, figs 3, 4) discussed the molecular phylogeny of the Hemichordata and provided a number of trees to demonstrate the relationships of modern enteropneusts. Their diagrams show a number of paraphyletic families like the Harrimaniidae and Ptychoderidae, from which other family taxa originate (the Saxipendiidae and Torquaratoridae). Even Pterobranchia is shown (Cannon et al. 2009, fig. 4) as originating as a sister group to Harrimaniidae + Saxipendiidae from within Enteropneusta. So it seems that there is no problem to accepting paraphyletic taxa.

It is advisable to discuss or at least state the paraphyletic nature of a taxon in the descriptions or remarks. Melchin et al. (2011), in their paper on the Neograptina indicated in their definition the mono- or paraphyly of some of their taxonomic units and this approach may be used as a guide here.

\section{Systematic palaeontology}

The duality of the available taxonomic approaches, a morphological or Linnaean style diagnosis of the taxa (based on Bulman 1955, 1970) and a definition based on a particular cladogram following de Queiroz \& Gauthier (1990), makes it difficult to generate a useful and consistent taxonomy. Morphological diagnoses are often impossible to be connected precisely to a phylogenetic definition. Clearly defined synapomorphies can be used in some cases to diagnose taxa and may help to integrate cladistic analyses into the here presented taxonomic approach. Melchin et al. (2011) provided definitions for family level taxa, which are based on a particular cladogram, but these can be translated into a diagnosis by using the defining synapomorphies. As a decision had to be made, cladistic definitions are used when available and remarks on the diagnostic features are provided in the discussions. Taxa, for which cladistic definitions are not available, are only diagnosed.

The family is regarded as the most useful rank to combine genera, as they combine a number of genera on morphological criteria and indicate a taxonomic and evolutionary relationship. Sepkowski (1979) for example, used families for his study of the early Phanerozoic diversity of the metazoans, as it was less likely to produce biases due to the lack of a fossil record or poor preservation of fossils. Many of the numerous families that have been established for graptolites may not be useful at all, as they were established on extremely poor material or because of the, at the time, unknown phylogenetic relationships of individual species and genera (e.g. Peiragraptidae: Jaanusson, 1960: Kalpinograptidae Jiao, 1977), but others may be referred to here also. Mu et al. (2002) for example described 62 family level taxa (families and subfamilies), many of questionable value for modern taxonomy. Subfamilies have been erected in a number of families, of necessity, as a great many genera would otherwise be included in a family and sufficient knowledge is available to effect subdivision (e.g. Cucullograptinae, Neocucullograptinae in Monograptidae: Urbanek 1958, 1966), but elevation of these to family level is not advisable at present.

Genera are listed under the families to which they are referred. All genera that I am aware of have been included in the lists, generally in alphabetical order and in their original spelling (e.g. Tetragrapsus, not Tetragraptus) for easy access to original literature, even though later name changes are sanctioned by ICZN (ICZN 1963) and should be followed. Taxa originally erected as subgenera are listed as if of full generic status for easy access only. No indication is provided regarding the synonymy of taxa, even though numerous synonyms have been established and a number of the genus names listed here may be quite unfamiliar, therefore. Often, taxa based on incomplete, fragmentary and macerated material have been described validly as new genera; for example, the "hydroid" fragments described by Kozłowski (1959), now in part recognized as stolonal fragments of rhabdopleurids (e.g. Mierzejewski 1986a). A specific identification of these may never be possible, however. I have, nevertheless, indicated their relationships by including them in families and accepting the interpretation of Mierzejewski (1986a) and others.

The inclusion in families is uncertain for a number of genera and the list provided here may have to be seen as preliminary, prone to revision. It is based on new information and suggestions and does not necessarily follow the previous Treatise editions of Bulman (1955, 1970). Due to space limitations, it is not possible to discuss each taxon and its inclusion in a certain group here. This should be the task for the next edition of the Treatise. 


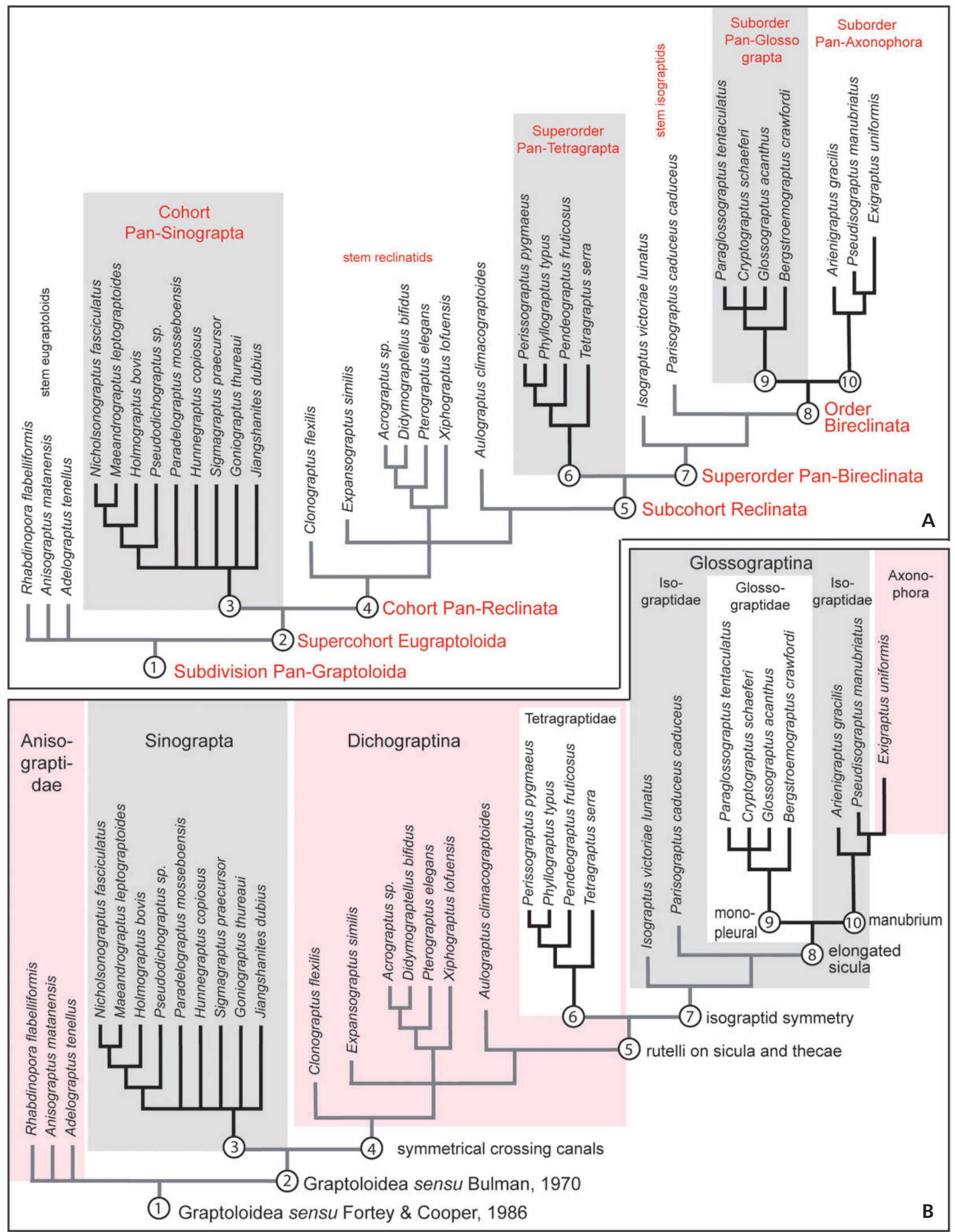

Figure 2. The Pan-Graptoloida (A), based on Maletz et al. (2009, fig. 2) with partial re-labeling (B). New taxa of Maletz et al. (2009) labelled in red in A. Coloured boxes for easier access only. Version B is preferred here. Inclusion of several taxa is questioned in text. 


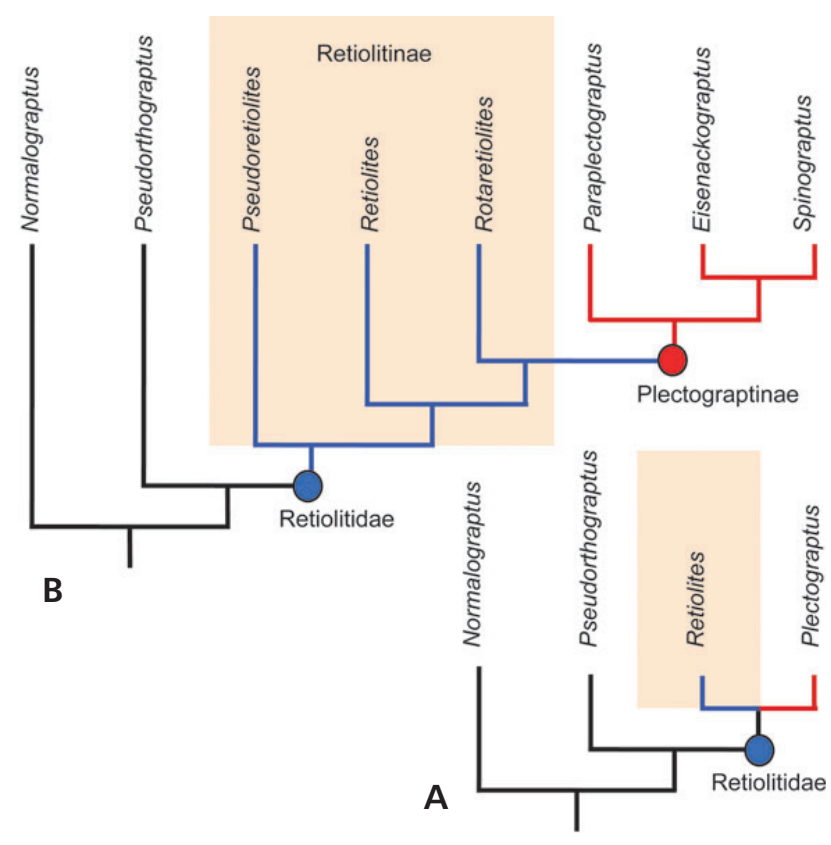

Figure 3. Cladistic relationship of the Retiolitidae, diagrams based on data from Bates et al. (2005). Retiolitine taxa in blue, Plectograptine taxa in red. $\bullet \mathrm{A}-$ Retiolitinae (Retiolites) and Plectograptinae (Plectograptus) as monophyletic sister taxa. $\bullet \mathrm{B}-$ a monophyletic Plectograptinae derived from a paraphyletic Retiolitinae.

\section{Repositories}

Illustrated specimens are in the following collections: CEGH-UNC - CICTERRA University of Cordoba, Argentina; GSC - fossil type collection of the Geological Survey of Canada, Ottawa, Ontario, Canada; IANIGLA - Department of Paleontology, Mendoza, Argentina; LO - Department of Geology, Lund University, Sweden; MB.G. - Museum für Naturkunde, Berlin, Germany; NMV - National Museum, Victoria, Australia; NMW - National Museum and Gallery of Wales, Cardiff; NYSM - New York State Museum, Albany, N.Y., U.S.A.; PMO - National History Museum, Oslo, Norway; SGU - Sveriges Geologiska Undersökning, Uppsala, Sweden; SMF - Forschungsinstitut Senckenberg, Frankfurt, Germany. All other specimens in collection of Jörg Maletz (Berlin, Germany).

Phylum Hemichordata Bateson, 1885 (p. 111)

Class Enteropneusta Gegenbaur, 1870 (p. 158)

Class Planctosphaeroidea van der Horst, 1936 (p. 612)

Discussion. - The taxonomy of the Hemichordata in general is not discussed herein. The classes Enteropneusta and Pterobranchia are well established, while the Planctosphaeroidea is an uncertain taxonomic unit, possibly based on the planktic larvae of some unknown enteropneusts (Spengel 1932, Hyman 1959, Cameron et al. 2000). Enteropne- usta are marine worms with a tripartite body and may be seen as a sister group to the Pterobranchia (Fig. 4), but do not produce a domicile or tubarium.

Some authors considered Pterobranchia and Enteropneusta as monophyletic taxa of the Hemichordata (e.g. Winchell et al. 2002, Cameron et al. 2005), while others suggested that the Enteropneusta are a paraphyletic group with the family Harrimaniidae as a sister group to the monophyletic Pterobranchia (Halanych 1995, Cameron et al. 2000, Bourlat et al. 2006, Cannon et al. 2009). Recently, however, Peterson et al. (2013) provided MicroRNA support for a monophyly of Enteropneusta.

Class Pterobranchia Lankester, 1877, p. 448

(= Graptolithoidea Beklemishev, 1951a, p. 269)

Definition. - (Mitchell et al. 2013, p. 52) The least inclusive clade containing Rhabdopleura normani Allman, 1869 (in Norman 1869), and Cephalodiscus dodecalophus M'Intosh, 1887.

Discussion. - Pterobranchia is regarded as a monophyletic taxon with the presence of the tubarium, a variably shaped domicile, as the defining synapomorphy. The tubarium is secreted from glands on the cephalic shield of the zooids. Pterobranchia are characterised through a colonial or "pseudo-colonial" lifestyle, originating from a sexually formed initial zooid. Additional zooids are asexually budded from the founding member. They show a constant organic connection (Graptolithina) or develop into separate individuals when mature (Cephalodiscida).

The zooids of Pterobranchia have a tri-partite body, differentiated into the cephalic shield, the collar with the arms and the trunk regions, differing considerably from the elongated worm-like body of the Enteropneusta (see Fig. 4). The cephalic shield bears the glands from which the tubarium is secreted. One (Rhabdopleura) or several (Cephalodiscus) pairs of arms with paired tentacles characterise the collar. The trunk is short and bears a u-shaped gut. A contractile stalk or stolon connects the individual zooids of Rhabdopleura, while in Cephalodiscus the stalk is short and provided with an attachment disc from which also new zooids are formed. These separate from their mother zooid when mature.

Lankester (1877) erected Pterobranchia for a single genus, Rhabdopleura and referred it to the Bryozoa, named Tentaculibranchia by him. He did not refer to the fossil graptolites, even though Allman (1872) and Nicholson (1872a, p. 80) already suggested a possible relationship between graptolites and the extant Rhabdopleura. At that time, the genus Cephalodicus was unknown to Science.

A close phylogenetic relationship of the Graptolithina and the Pterobranchia has been postulated through investi- 
gation of the tubarial tissues (e.g. Andres 1977, 1980; Crowther 1981) and was discussed in some detail by Urbanek (1986). Mitchell et al. (2013) provided strong support for this relationship through a cladistic analysis of the tubarium characteristics including extant pterobranchs and fossil graptolites (Fig. 5). The results indicate an inclusion of the extant Rhabdopleura with the otherwise extinct group of the benthic graptolites.

Beklemishev (1951a, b, 1964, 1970) had already used the class Graptolithoidea with the orders Rhabdopleuroidea and Cephalodiscoidea and including the graptolite orders Stolonoidea, Camaroidea, Tuboidea, Dendroidea and Graptoloidea. Beklemishev, thus, did not include the extant pterobranchs in the graptolites, but extended the concept of the "graptolites" and synonymised the Pterobranchia with his more extensive class Graptolitoidea. Some graptolite workers followed his classification (see discussion in Urbanek 1986). It is here preferred to keep the name Pterobranchia as an umbrella for all hemichordates secreting a tubarium (termed rhabdosome in planktic Graptoloidea) and use the term Graptolithina for its colonial members (following Mitchell et al. 2013).

Dramatic differences in organismal size, and especially the development of a secreted housing construction, the tubarium (rhabdosome) generally differentiate the Pterobranchia from the worm-like Enteropneusta; however, extremely small members of the Enteropneusta have been discovered recently (Worsaae et al. 2012). All Graptolithina are also colonial, but the Cephalodiscida have a pseudo-colonial life style with unconnected mature zooids asexually budding new zooids from the short stalk (Fig. 6F). This interpretation differs little from the Bulman $(1955,1970)$ concept of an extinct class Graptolithina, separate from the extant Pterobranchia. It makes it possible to understand the graptolites from a modern point of view. As the zooids of the recent Rhabdopleura are well known (Fig. 6H, I), they can now be used as a model for the zooids of the extinct taxa also (as was done by inference earlier: Crowther \& Rickards 1977) (Fig. 1B).

Subclass Cephalodiscida Fowler, 1892 (p. 297)

(= Cephalodiscoidea Beklemishev, 1951)

Diagnosis. - Same as family.

Family Cephalodiscidae Harmer, 1905 (p. 5)

(incl. Eocephalodiscidae Kozłowski, 1949, p. 195)

Diagnosis (herein). - Pterobranchia with separate mature zooids, forming "pseudo-colonies" in various complex shapes from assemblages of individual, separate tubes to communal tubaria; one genus (Atubaria) without known tubarium; a differentiation of a sicular zooid or a sicular tuba-

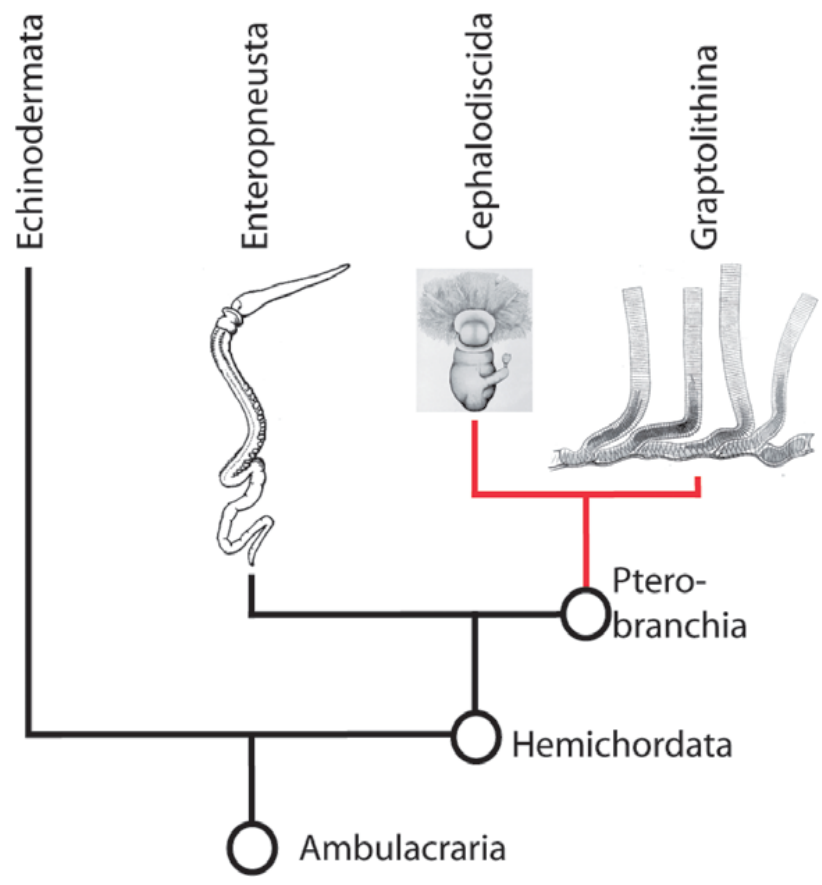

Figure 4. Cladistic diagram (based on Maletz 2013, fig. 2) showing the general phylogenetic relationships of the Hemichordata.

rium is not present; zooids with several pairs of tentaculated arms; tips of arms sometimes with club-like extensions.

Genera included. - Acoelothecia John, 1931; Aellograptus Obut, 1964; Atubaria Sato, 1936 (Fig. 6G); Cephalodiscus M'Intosh, 1882 (Fig. 6C, E, F) [non Cephalodiscus Berlese, 1916; Arachnida], Demiothecia Ridewood, 1906; Eocephalodiscus Kozłowski, 1949; Idiothecia Lankester, 1906 in Ridewood (1906) (Fig. 6A, B); Melanostrophus Öpik, 1930; Orthoecus Andersson, 1907; Pterobranchites Kozłowski, 1967.

Discussion. - The Cephalodiscida may be recognized as a monophyletic taxon based on the available data (see Cannon et al. 2009, Mitchell et al. 2013). The group is known from a few extant taxa and some possible fossil cephalodiscid tubaria, but the phylogenetic relationships to the Enteropneusta are uncertain. Rickards \& Durman (2006) indicated that Cephalodiscidae is more closely related to the "graptolites" than Rhabdopleuridae, suggesting that the non-colonial organisation is a secondary development. However, Mitchell et al. (2013) re-analysed the data and found that Cephalodiscus and Rhabdopleura were part of an unresolved basal polytomy.

Cephalodiscida includes all pterobranchs with a noncolonial lifestyle. The zooids of a cephalodiscan "pseudocolony" originate through asexual budding from each other, but separate when mature. The tubaria consist of individual tubes, closed at the origin or of communal tubaria shared 
by their members (Fig. 5M, N). Taxa with communal tubaria may be difficult or even impossible to separate from Graptolithina in the fossil record when the anatomy of the zooids is unknown.

The inclusion of the extant genus Atubaria (Sato 1936, Komai 1949) is based on the zooidal anatomy (Fig. 6G) as the taxon is only known from individual, separate zooids without any indications of the secretion of a tubarium. The anatomy of the Atubaria zooids differs little from that of Cephalodiscus (see Fig. 6F, G). It is uncertain, whether Atubaria heterolopha produces a tubarium or not. A stolon system connecting the individual mature zooids is lacking in Cephalodiscida.

The inclusion of fossil taxa in Cephalodiscida is often difficult, as details of the tubarium design are often not available and the individuality of the mature zooids cannot be ascertained. In modern cephalodiscid taxa the colony design is highly variable in the various subgenera (see Figs 5M, N, 6A, C, E), even though zooidal morphology varies little. Thus, a detailed comparison of extant and extinct taxa is not possible. It is not necessary to subdivide the Cephalodiscida or introduce any additional higher-level taxon units, as a single family is included. The description of the Eocephalodiscidae in Kozłowski (1949) is in all details comparable with the diagnosis of the Cephalodiscidae. Therefore, there is no reason to keep a separate family Eocephalodiscidae for fossil cephalodiscids.

Subclass Graptolithina Bronn, 1849 (p. 149)

Definition. - (Mitchell et al. 2013, p. 52) Graptolithina is defined as a lineage-based taxon that includes all taxa sharing a more recent common ancestry with Rhabdopleura than with Cephalodiscus.

Discussion. - The name Graptolithina originates from the genus name Graptolithus, introduced by Linnæus (1735) for a feature "resembling a fossil". For a long time Graptolithus was used for numerous graptolite species and only a few additional genera were created (e.g. by Hall 1865). It later became the general term for graptolite fossils and was not used in publications as a genus name any more (see Elles \& Wood 1902, Bulman 1929 for discussion). Gurley (1896, p. 98) was first to suggest abandoning it as a generic name.

The monophyletic Graptolithina includes all pterobranchs with a colonial development as the defining synapomorphy (Fig. 5). Mitchell et al. (2013) indicated the "serial budding from an interconnected stolon system" as the defining synapomorphy of all Graptolithina. The presence of a larval vesicle or prosicula and the regular zigzag fusellae are more difficult to establish from fossil taxa. However, also the presence of a stolon system is in most cases also inferred only through the interconnection of the individual thecae of the tubaria (see remarks on communal tubaria in Cephalodiscidae). A precise construction of thecal tubes with a zigzag suture as in creeping tubes of Rhabdopleura and in derived Graptolithina may not be developed in early taxa (see Durman \& Sennikov 1993).

The extant Rhabdopleura is included in Graptolithina, following Mitchell et al. (2013), but Cephalodiscida is not. This inclusion of Rhabdopleura in Graptolithina is a major step in the understanding of the fossil Graptolithina of which it is the only modern representative.

The differentiation of benthic taxa above the family level within the early Graptolithina is fairly poor (Fig. 5) and a formal differentiation of higher-level taxonomic units is not advocated at the moment. The families Rhabdopleuridae, Cysticamaridae and Wimanicrustidae are here provisionally separated using previously established family group taxa (see Kozłowski 1949, Bulman 1970). They are not included in Dendroidea or Graptoloidea, as they do not possess the defining characteristics of these, especially the thecal differentiation and triad budding system. Mitchell et al. (2013) show Bulmanicrusta and Bithecocamara as sister taxa (Fig. 5), but very few taxa of the camaroids and crustoids were analysed due to lack of morphological data and a conclusion of their phylogenetic relationships is impossible to gain.

\section{Graptolithina incertae sedis}

Discussion. - The inter-relationships of the benthic families Rhabdopleuridae, Cysticamaridae, Wimanicrustidae, Dithecodendridae and Cyclograptidae are unclear. They are here not referred to a defined order of the Graptolithina, and are listed under the heading Graptolithina incertae sedis to show the uncertainty of their status. Further research may provide a better understanding of the evolutionary status and differentiation of these taxa. There is no doubt, however, that the taxa can be referred to the Graptolithina and that they represent basal members of the taxon.

\section{Family Rhabdopleuridae Harmer, 1905 (p. 5)}

Diagnosis (emended). - Colonial pterobranchs with encrusting tubular constructions with irregular fusellar rings or regular zigzag sutures in creeping and erect tubes; resorption porus for the origination of new tubes; erect thecal tubes parallel-sided or slowly widening, with unornamented apertures; zooids connected through robust stolon system (black stolon); sicular zooid secretes featureless domal prosicula.

Genera included. - ?Archaeocryptolaria Chapman, 1919; Calyxhydra Kozłowski, 1959; Chitinodendron Eisenack, 


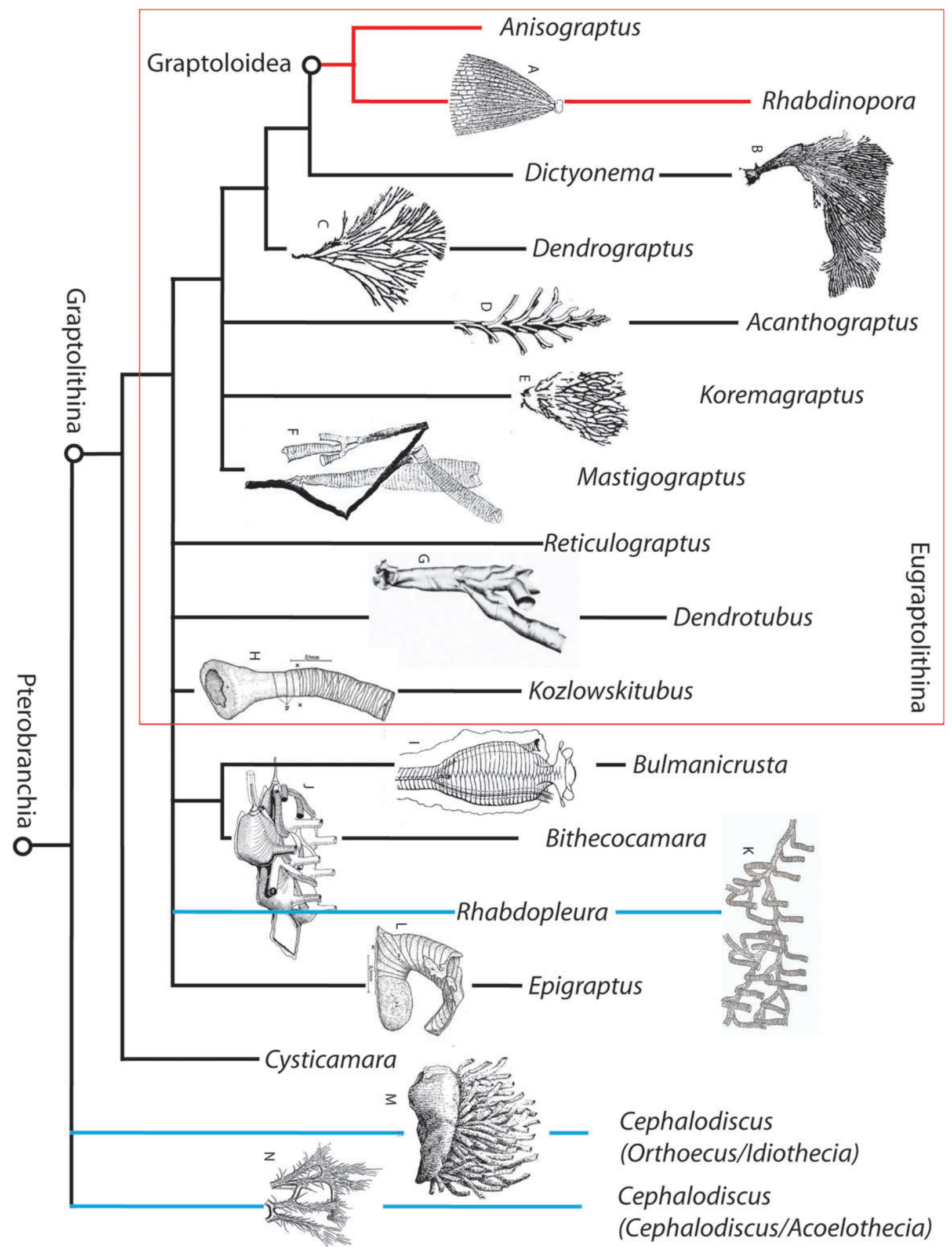

Figure 5. The Graptolithina, based on data and interpretations in Mitchell et al. (2013), showing the inclusion of Rhabdopleura and the poor resolution of the early graptolites. 

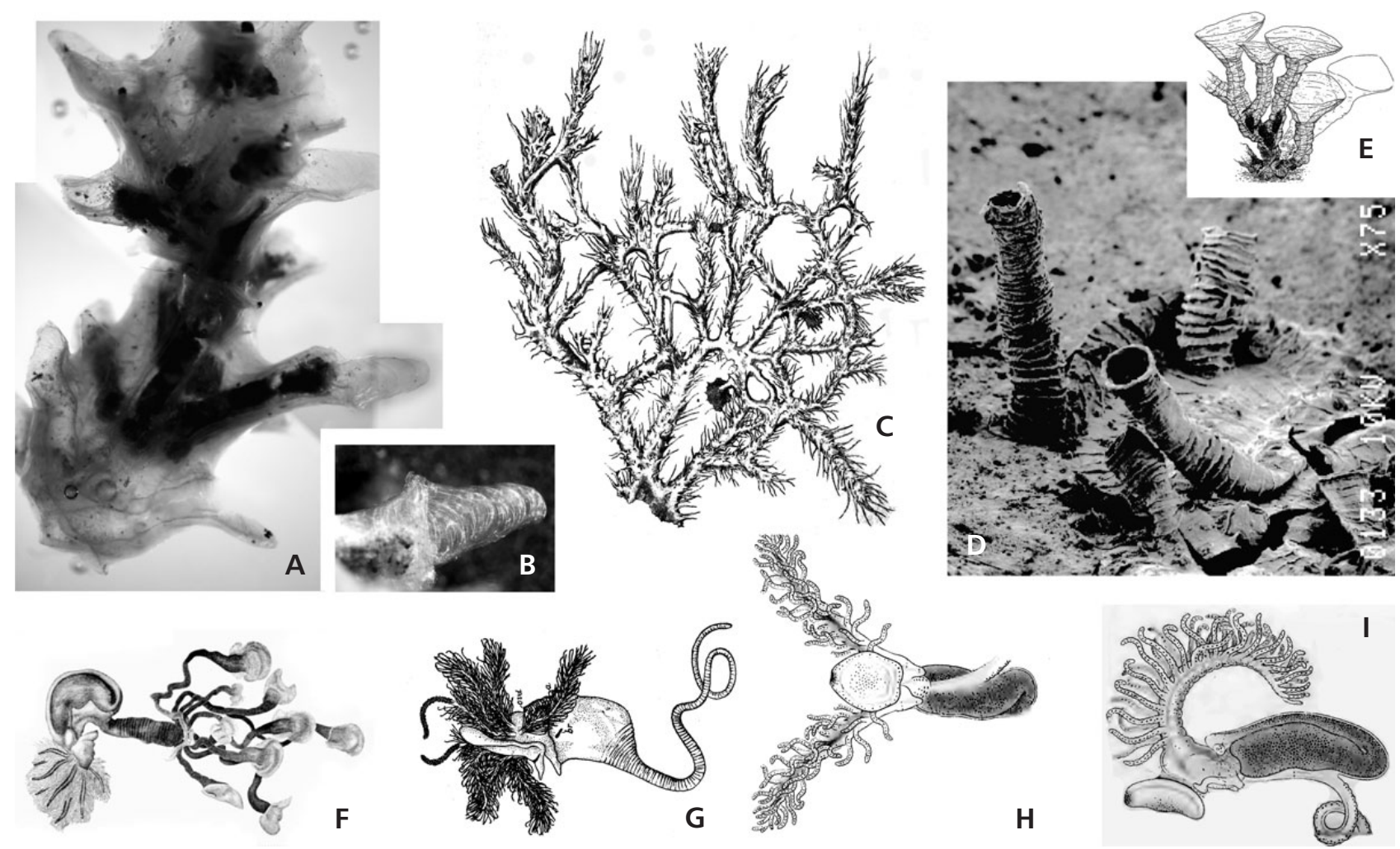

Figure 6. A. Tubaria and zooids in modern Pterobranchia. • A, B - Cephalodiscus (Idiothecia) levinseni Harmer, SMF 75728, part of colony (A) and rutellum with fusellar structure (B), dark spots are preserved zooids. $\bullet$ C - Cephalodiscus dodecalophus M'Intosh, part of large branched tubarium with numerous apertural spines (from M'Intosh 1887, pl. 1). - D - Rhabdopleura compacta Hincks, SMF 75727, SEM photo showing encrusting tubes with zigzag sutures and erect tubes with full fusellar rings. - E - Cephalodiscus calciformis Emig with widening openings, based on Emig (1977). - F-Cephalodiscus fumosus John, mature zooid with budding individuals (from John 1931). • G - Atubaria heterolopha Sato, mature zooid (from Komai 1949, fig. 1). • H, I - Rhabdopleura normani Allman, dorsal (H) and lateral (I) views of single zooid (after Sars 1874, pl. 1).

1937; Cylindrohydra Kozłowski, 1959; Diplohydra Kozłowski, 1949; Eorhabdopleura Kozłowski, 1970; Epigraptus Eisenack, 1941; Fasciculitubus Obut \& Sobolevskaya, 1967; Graptovermis Kozłowski, 1949 (Fig. 7C); Haliolophus Sars, 1868; ?Haplograptus Ruedemann, 1933; Idiotubus Kozłowski, 1949 (Fig. 7E); Kystodendron Kozłowski, 1959; Lagenohydra Kozłowski, 1959; ?Malongitubus Hu, 2005; Palaeokylix Eisenack, 1932; Palaeotuba Eisenack, 1934; Rhabdopleura Allman, 1869 in Norman (1869) (Fig. 6D, H, I); Rhabdopleurites Kozłowski, 1967; Rhabdopleuroides Kozłowski, 1961; Rhabdotubus Bengtson \& Urbanek, 1986 (Fig. 8A, B); ?Sphenoecium Chapman \& Thomas, 1936; Sphenothallus Chapman, 1917 (non Sphenothallus Hall, 1847: uncertain tubular fossil, see Fatka et al. 2012), Stolonodendrum Kozłowski, 1949a; Xenotheca Eisenack, 1937; ?Yuknessia Walcott, 1919.

Discussion. - Rhabdopleuridae is a taxon including graptoloids with simple, parallel-sided encrusting tubes and erect, parallel-sided or slowly widening zooidal tubes with unornamented apertures. The encrusting tubes show either irregularly placed sutures or distinct dorsal zigzag sutures (Rhabdopleura). The erect zooidal tubes have irregular su- tures or fusellar halfrings and may possess distinct collar structures. A featureless dome in place of a sicula is known from a few taxa (Rhabdopleura, Epigraptus), but for most taxa the development is uncertain as the available material consists of fragments of the tubes or the stolons only (see Mierzejewski 1986a).

The Rhabdopleuridae includes Rhabdopleura the only genus in which zooidal anatomy is known, and thus, the only graptoloid of which we have any information of the zooidal development. The zooids of Rhabdopleura show the tri-partite body development known from Cephalodiscus, but differ from those and from Atubaria by the development of only a single pair of arms (Fig. 6H, I) and the constant, life-long connection to the stolon system. Additional minor anatomical differences exist.

Mitchell et al. (2013) indicated the possible differentiation of an informal group of "rhabdopleurids" as a paraphyletic taxon (Mitchell et al. 2013, fig. 6c) including Rhabdopleura, Epigraptus and Cysticamara.

The proximal dome is known in Rhabdopleura and Epigraptus (Fig. 5L) only, but the complete tubarium development is uncertain for most members. Therefore, early taxa are largely included due to their benthic, creeping 
Figure 7. Encrusting graptoloids showing the fragmentary preservation of colonies (based on Kozłowski 1949, 1971). - A, B - Cysticamara accolis Kozłowski. $・ \mathrm{C}-$ Graptovermis intestinalis Kozłowski. $\bullet \mathrm{D}-$ Epigraptus sp., showing domal prosicula. $・ \mathrm{E}-$ Idiotubus bilinguis Kozłowski. • F - Tubicamara coriacea Kozłowski. Magnification approximate only.
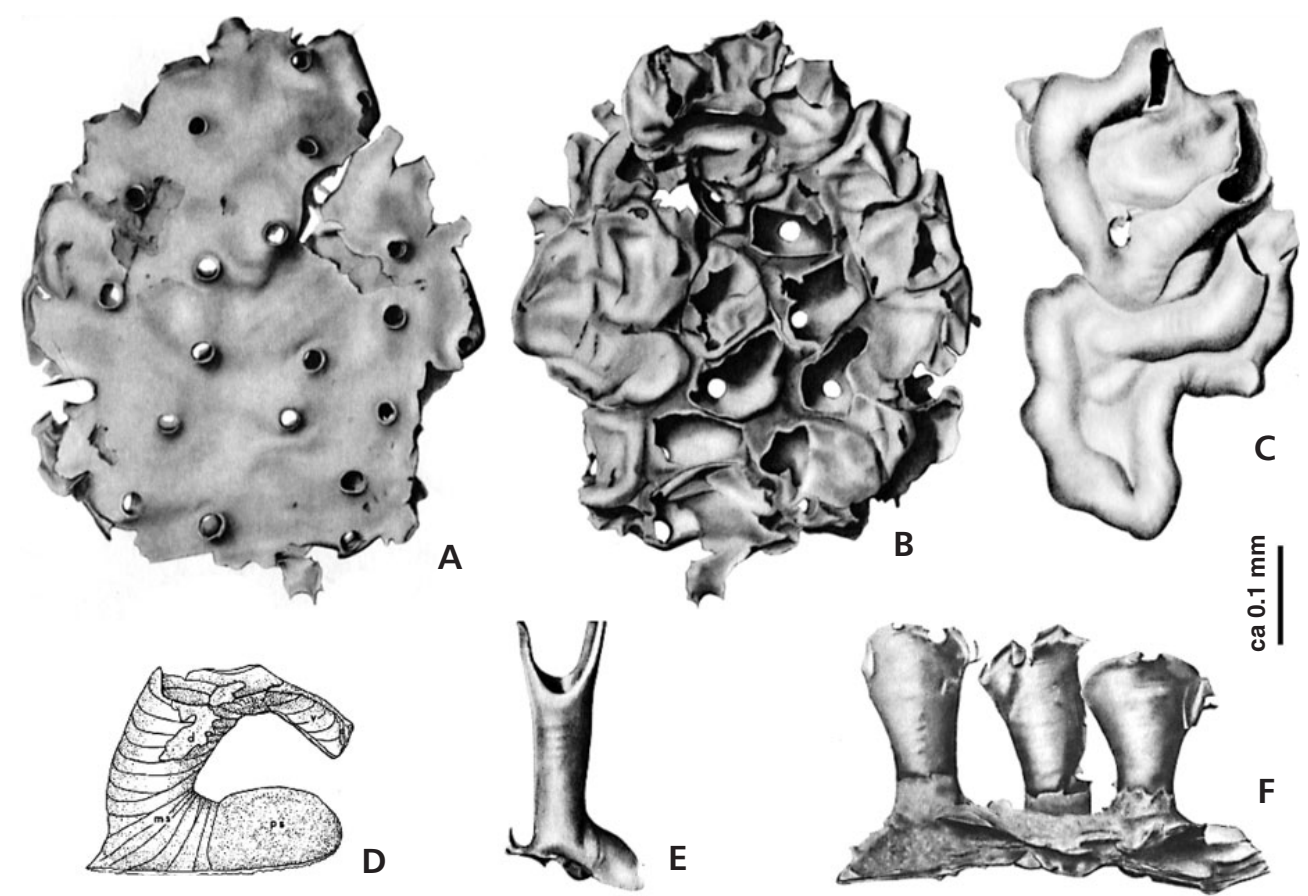

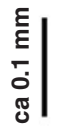

habit and the simple style of their thecal tubes. Rhabdopleuridae is here strongly extended to include early encrusting taxa with considerable differences in tubarium construction to the extant members.

The Middle Cambrian "Rhabdopleura" obuti Durman $\&$ Sennikov, 1993 is one of the earliest known members of the Rhabdopleuridae, but lacks most of the characters of the tubarium in Rhabdopleura, even the regular zigzag sutures on the dorsal side of the creeping tubes and the collars of the erect tubes, so typical of the modern, extant Rhabdopleura (Fig. 6D). Both features may have been derived late in the evolution of the group and are recognizable first in Lower Ordovician taxa (e.g. Mierzejewski 1986a). The presence of colonies with full fusellar rings and collars as in Rhabdopleura and Kystrodendrum is therefore regarded as a character of derived rhabdopleurids.

Mierzejewski (1986a) suggested the inclusion of a number of hydroids described by Kozłowski (1959) as stolonal remains of rhabdopleurids. This is supported here, but a synonymy with Rhabdopleura is not proposed and may be impossible to establish.

The precise age of the oldest rhabdopleurids is still uncertain. Steiner \& Maletz (2012) referred the Middle Cambrian ?Cephalodiscus sp. of Maletz et al. (2005) to the earliest members of the group and recognized Yuknessia from the Burgess Shale as one of the earliest pterobranch hemichordates. According to the authors, also the Burgess Shale taxon Dalyia Walcott and the genus Malongitubus $\mathrm{Hu}$ from the Chenjiang Biota of China may belong to the Pterobranchia.

Family Cysticamaridae Bulman, 1955 (p. 42)

Diagnosis (emended). - Encrusting Graptolithina with the characteristic camara, an inflated chamber and an erect neck; stolon system with modified diad budding, forming a bifurcating network above camarae or represented by extracameral tissue surrounding stolons.

Genera included. - Bithecocamara Kozłowski, 1949; Cysticamara Kozłowski, 1949 (Fig. 7A, B); Erecticamara Mierzejewski, 2000; Flexicollicamara Kozłowski, 1949; Graptocamara Kozłowski, 1949; Syringataenia Obut, 1953; Tubicamara Kozłowski, 1949 (Fig. 7F).

Discussion. - Cysticamaridae (= order Camaroidea Kozłowski, 1938) is characterized by the typical camara, a creeping tube with a considerable inflation (Fig. 10A, B) and an erect neck with the thecal aperture (Fig. 7F). All members of the order Camaroidea Kozłowski, 1938 are included herein. Bulman (1955) differentiated Bithecocamara (Fig. 5J) in its own family Bithecocamaridae. Only parts of the colonies are known and the housing of the initial zooid, the sicula, has not been described from any of the taxa. A further differentiation of the camaroids into families is not advocated here, nor is the retention of the camaroids in their own order. The combined "Camaroidea" and "Crustoidea" might actually represent a single group of encrusting graptolites. Both possess inflated thecae (camearae) and differences are found in the shape of thecal apertures in the development of the stolon systems. The importance of these differences cannot be estimated at the moment. 
The status of the Cysticamaridae is unclear. It may be a completely artifical unit, based on the assumption of the homology of the camara by Kozłowski (1938), but the presence of bifurcating ("diad budding") of the stolons may indicate their closer relationships. Mitchell et al. (2013, fig. 6c) included two cysticamarid taxa in their analysis, but the closer relationships between both still remain uncertain. The authors included Cysticamara in the informal "rhabdopleurids" and referred Bithecocamara together with the crustoid Bulmanicrusta to a possibly monophyletic group, the informal "camarates" not further mentioned in their text. This appears questionable, as Bulmanicrusta was described to show triad budding (Kozłowski 1949, Bulman 1970), but was coded as having diad budding by Mitchell et al. (2013) and it is here preferred to keep Cysticamara and Bithecocamara in one group. Bulmanicrusta with a typical triad budding system then has to be referred to the crustoids (family Wimanicrustidae).

Family Wimanicrustidae Bulman, 1970 (p. 52)

Diagnosis (emended). - Encrusting Graptolithina with the characteristic camara an inflated chamber and an erect neck with often complex apertural modifications; stolon system with triad budding

Genera included. - Bulmanicrusta Kozłowski, 1962 (Fig. 5I); Ellesicrusta Kozłowski, 1962; Graptoblastoides Kozłowski, 1949; Graptoblastus Kozłowski, 1949; Holmicrusta Kozłowski, 1962; Hormograptus Öpik, 1930; Lapworthicrusta Kozłowski, 1962; Maenniligraptus Mierzejewski, 1986b; Ruedemannicrusta Kozłowski, 1962; Thallograptus Öpik, 1928 (non Thallograptus Ruedemann, 1925: algae), Urbanekicrusta Mierzejewski, 1986b; Wimanicrusta Kozłowski, 1962; Xenocyathus Eisenack, 1982.

Discussion. - Like Cysticamaridae, Wimanicrustidae may be an artificial taxonomic unit, based on Kozłowski (1938) and includes material of fragments of encrusting graptoloids with inflated camarae and a triad budding. Bulman (1970, p. 52) described the family Hormograptidae based on the single, poorly known genus Hormograptus. Mitchell et al. (2013) included Bulmanicrusta as the only genus of the group in their analysis and referred the genus to the informal "camarates" indicating a possible close relationship to the Cysticamaridae.

The Wimanicrustidae is known only from very fragmentary material, often of isolated single thecae. Thus, the development of the colonies and their shapes is impossible to judge for most taxa included in the crustoids. The differentiation of Wimanicrustidae and Cysticamaridae can be based on the presence of a triad budding system of the stolons in the crustoids and a diad budding in camaroids.
While Wimanicrustidae are represented largely by runner-type colonies, Cysticamaridae are more compact or thigmophylic. The initial part of the colony, the sicula, is unknown in both groups, but Kozłowski (1971) referred an isolated sicula to the Crustoidea.

\section{Family Dithecodendridae Obut, 1964, p. 295}

Diagnosis. - Erect Graptolithina with a slender, often branching stem with thick cortical cover; slender and long tubular metathecae individual to multiple, slowly widening, formed of thin fusellum with irregular sutures.

Genera included. - Archaeolafoea Chapman, 1919; Bulmanidendrum Obut, 1974; ?Dalyia Walcott, 1919; Dithecodendrum Obut, 1964; Karasidendrum Sennikov, 1998; Ovetograptus Sdzuy, 1974; Protodendrum Sennikov, 1998; Siberiodendrum Obut, 1964; Sibiriograptus Obut, 1964; Sotograptus Sdzuy, 1974; Tarnagraptus Sdzuy, 1974.

Discussion. - Dithecodendridae represents a difficult taxonomic unit of erect, benthic taxa, of which the colony construction is very poorly known. None of the taxa was well enough known to be included in the analysis of Mitchell et al. (2013). Rickards \& Durman (2006) included number of taxa in the order Dithecoidea and showed the genera Archaeolafoea, Mastigograptus and Sotograptus as a clade in their diagrams. Of these, Mastigograptus has here been excluded from the Dithecodendridae due to the recognition of a triad budding system and is referred to the Mastigograptidae. The development of the stolons is unclear in the remaining taxa.

It is currently uncertain, whether the Dithecodendridae belong to Eugraptolithina of Maletz et al. (2009) or should be considered as basal Graptolithina. None of these taxa is known from relief or isolated material, and the sicular development is completely unknown. A number of taxa can be shown to be graptolites based on the presence of fuselli (Rickards \& Durman 2006), while the rest is included only due to the general shape of the colonies. Previously, Mierzejewski (1986a) referred several Middle Cambrian genera to the hydroids.

The taxa in general possess slender stipes with an alternating origin of the long and slender, often slightly widening metathecae, in part similar to those of the genus Mastigograptus, but the presence of a triad budding system is unlikely due to the alternation of thecae along the stipes. Dithecodendridae includes the earliest erect growing benthic graptolites and precedes most of the encrusting taxa described by Kozłowski (1949) and others. Johnston et al. (2009) illustrated a number of erect "dithecoid"-like bushy graptolites from Burgess Shale-type biota at Haiduk and Tangle Peaks, British Columbia, which may represent the oldest taxa of this group. The material originates from the 

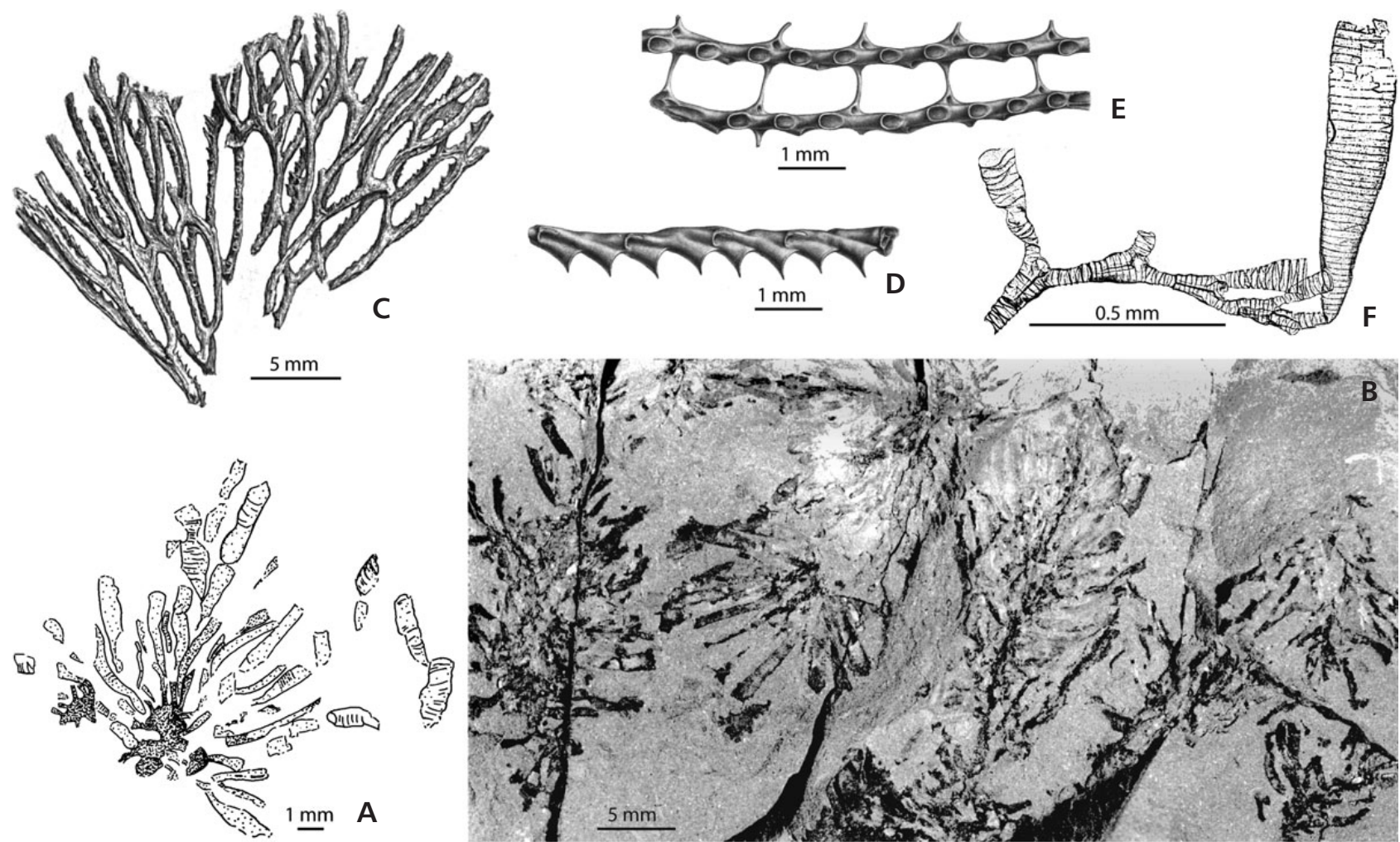

Figure 8. Encrusting and dendroid graptoloids. • A, B - Rhabdotubus robustus Maletz, Steiner \& Fatka (Maletz et al. 2005), colonies with encrusting thecorhiza and erect tubes, showing fuselli. • C - Desmograptus idoneus Bulman (Bulman 1933, pl. 4), part of colony. • D, E - Rhabdinopora flabelliformis (Eichwald) (Bulman 1933, pl. 1), showing development of autothecae and bithecae. • F - Micrograptus sp. (Andres 1977) showing triad budding and form of isolated thecae.

Bolaspidella trilobite zone of Drumian age and is thus slightly younger than the Burgess Shale from which graptolites have not been identified with certainty.

Family Cyclograptidae Bulman, 1938 (p. 22)

[= Tubidendridae Kozłowski 1949, p. 160;

homonym of Tubidendridae Nutting, 1905, p. 940:

Hydrozoa]

Diagnosis (emended). - Largely encrusting Graptolithina with tubular thecae; often forming short erect branches in which the thecae are serially arranged; thecal development in diads with autothecae and bithecae, the latter often restricted to the thecorhiza.

Genera included. - ?Alternograptus Bouček, 1956; ?Callodendrograptus Decker, 1945; Calycotubus Kozłowski, 1949; Camarotubus Mierzejewski, 2001; Conitubus Kozłowski, 1949; Cyclograptus Spencer, 1883; Dendrotubus Kozłowski, 1949; Discograptus Wiman, 1901; Dyadograptus Obut, 1960; Galeograptus Wiman, 1901; Kozlowskitubus Mierzejewski, 1978 (Fig. 5H); Marsipograptus Ruedemann, 1936; Multitubus Skevington, 1963; Parvitubus Skevington, 1963; Reticulograptus Wiman, 1901; Rhiphi- dodendrum Kozłowski, 1949; Rodonograptus Počta, 1894; Siberiodendrum Obut, 1964; Syrriphidograptus Poulsen, 1924; Tubidendrum Kozłowski, 1949.

Discussion. - As Bulman (1938) already established the family Cyclograptidae for this group, the Tubidendridae Kozłowski, 1949, a homonym of Tubidendridae Nutting, 1905 , becomes a junior synonym of this taxon. Bulman (1955, p. 22) quoted the Cyclograptidae, but did not use the name in the taxonomic part and did not refer to it in the second edition of the Treatise (Bulman 1970).

Cyclograptidae includes a number of benthic graptolites with encrusting to erect, bushy colonies and tubular thecae with a diad budding system. Mitchell et al. (2013, fig. 6) recognized an informal group, the "tuboids" including the genera Kozlowskitubus and Reticulograptus in their analysis, but did not discuss the group.

The taxa included in Cyclograptidae were previously referred to the two families Tubidendridae and Idiotubidae (Kozłowski 1949, Bulman 1970). They are here combined into one group based on their encrusting habit and the presence of groups of tubular erect thecal tubes. Quite a number of the genera may actually belong to other groups such as are Rhabdopleuridae, Cysticamaridae or Wimanicrustidae, but details of their initial colony growth are unknown. 
Cyclograptidae, thus, can be seen as a "portmanteau" for benthic, encrusting graptolite taxa. The sicular (initial) development is barely known in any of these taxa. Kozłowski (1963, fig. 1) and Kozłowski (1971, fig. 5) illustrated bottle-shaped siculae with partial helical line in the prosicula and referred it to Dendrotubus (now Kozlowskitubus) erraticus (Fig. 8H).

Mitchell et al. (2013) separated the first taxon with a helical line in the prosicula and all its descendants as the paraphyletic Eugraptolithina. The authors included the three genera Dendrotubus, Kozlowskitubus and Reticulograptus in their analysis and referred to these taxa as the basal Eugraptolithina.

Eugraptolithina Mitchell et al., 2013 should not be confused with Eugraptoloida Maletz et al., 2009. Mitchell et al. (2013, p. 53) erected the Eugraptolithina as the holophyletic, apomorphy-based taxon that includes the first graptolite that acquired a prosicula with a helical line and all its descendants, basically including all Dendroidea and Graptoloidea as defined herein. The origin and early evolution of this feature, however, is quite unclear, as its presence can be ascertained in very few benthic taxa only, while it is present in all planktic graptolites. The presence of a helical line on the sicula is based on three isolated siculae referred to Kozlowskitubus (Kozłowski, 1963: Dendrograptus erraticus Kozłowski), of which two specimens show this possible helical line. The sicula and its development are not known from any other Cyclograptidae. Therefore, the basal members of this clade, identified as members of the Cyclograptidae herein, cannot be identified with any confidence. Mitchell et al. (2013), especially discuss the genus Dendrotubus and its influence that its inclusion or exclusion in the analysis has. The sicula is not known in Dendrotubus, but the cladistic analysis indicates the inclusion of the genus in the Eugraptolithina (Mitchell et al. 2013, p. 47). Interestingly, an exclusion of Dendrotubus increases the resolution of the eugraptolithines in the analysis.

The introduction of a helical line in the prosicula (see Fig. 5H) may potentially be an important event in graptoloid evolution, but at the moment, it is not useful at all, questioning the value of the taxon Eugraptolithina. Too few juvenile specimens of benthic, dendroid graptolites are known to show the construction of the initial colony and to interpret the evolutionary patterns. The presence of the helical line in the prosicula may also be related to an upright, erect growth of the colonies, which appears to be typical of the Dendroidea. However, some taxa of the Cyclograptidae already possess an erect growth of the stipes and overlap in their tubarium features with the Dendroidea.

The triad budding of many dendroid graptolites may be more useful to delimit the group, but its phylogenetic origins are shrouded in mystery. Most geologically important graptolites belong to the Eugraptolithina. Two main groups, Dendroidea and Graptoloidea can be differentiated, based on the presence of a nematophorous sicula
(Graptoloidea) or a tubular sicula (Dendroidea), leading to the interpretation of a benthic, sessile (Dendroidea) or planktic (Graptoloidea) lifestyle. It is useful to keep these two main taxon names as they are well established and useful and their definition has not changed considerably from previous use (e.g. Bulman 1970).

Mitchell et al. (2013, fig. 6) indicated an informal paraphyletic group as the "dendroids", but did not discuss the group further. The group also included the genus Mastigograptus, here referred to the Mastigograptidae and several taxa of the Acanthograptidae.

Order Dendroidea Nicholson, 1872b (p. 101)

(= Cladophora Hopkinson, 1875

in Hopkinson \& Lapworth 1875, p. 634)

Diagnosis (emended). - Benthic graptoloids with variable colony shape; erect, bushy or fan-shaped tubarium; thecae serially arranged along the stipes with regularly placed bithecae based on a triad budding concept; thecal development variable from tube-shaped to distinctly widening and with ventral rutellum; anastomosis or dissepiments present in some taxa; sicular development largely unknown.

Discussion. - Dendroidea includes most of the non-nematophorous graptoloids with a bush- or tree-shaped colony development, possessing a triad-budding system and a distinct thecal differentiation. Bushy growth, however, also appears in some Cyclograptidae, in which the encrusting part may be reduced in size. The genera are usually defined from tubarium fragments, based on general constructional features. Proximal ends and siculae are rarely known in enough detail to understand the real phylogenetic relationships. The taxon is used for stability (of nomenclature) reasons. A phylogenetic analysis of all groups of these benthic graptolites and their relationships does not exist and is unlikely to be provided soon.

Mitchell et al. (2013) did not provide any indication or opinion on the differentiation of the "dendroid", benthic graptolites. The earlier differentiation into several families (see Chapman et al. 1993) indicates, that differences and similarities can be used to group the individual genera into higher rank taxa, but little information on the important initial colony development exists.

Family Dendrograptidae Roemer, 1897

in Frech (1897) (p. 568)

(incl. Pseudodictyonemidae Chapman et al. 1993, Stelechocladiidae Chapman et al. 1993).

Diagnosis (emended). - Benthic graptoloids with variable colony shape; erect, bushy or fan-shaped tubarium; thecae 
serially arranged along the stipes with regularly placed bithecae based on a triad budding concept; anastomosis or dissepiments present in some taxa; sicular development largely unknown; autothecae widening towards the apertures, possessing a vental lip or rutellum, sometimes with complex apertural modifications.

Genera included. - Airograptus Ruedemann, 1916; Aspidograptus Bulman, 1934; ?Cactograptus Ruedemann, 1908; Callograptus Hall, 1865; Calyxdendrum Kozłowski, 1960; Capillograptus Bouček, 1957; Dendrograptus Hall, 1858 (Fig. 5C); Denticulograptus Schmidt, 1939; Desmograptus Hopkinson in Hopkinson \& Lapworth, 1875 (Fig. 8C); Dictyonema Hall, 1851 (Fig. 5B); Graptolodendrum Kozłowski, 1966; Licnograptus Ruedemann, 1947; Odontocaulis Lapworth, 1881; Ophigraptus Jaeger, 1992; Ophiograptus Poulsen, 1937; Pseudocallograptus Skevington, 1963; Pseudodictyonema Bouček, 1957; Ptilograptus Hall, 1865; Ptiograptus Ruedemann, 1908; Rhabdinopora (Dictyograptus) Paškevičius, 2011; Rhizograpsus Spencer, 1878; ?Ruedemannograptus Termier \& Termier, 1948; Stelechiocladia Počta, 1894; Streptograptus Ruedemann, 1947 [non Streptograptus Yin, 1937: see Monograptidae], Zigzagigraptus Yu, 1962.

Discussion. - Dendrograptidae may represent a paraphyletic taxon from which the derived planktic graptoloids originated. Mitchell et al. (2013, fig. 6) showed the "dendroids" as a paraphyletic unit including a number of genus level taxa that are here informally referred to a variety of family level taxa (e.g. Acanthograptidae, Mastigograptidae) between which the precise phylogenetic relationships are unclear.

Most taxa are poorly known, from flattened shale material or isolated stipe fragments. Thus, their proximal end development and sicular construction are unknown. The erect growth of their colonies may be regarded as a defining character of Dendrograptidae. The thecae are generally serially arranged on the stipes and possess the typical triad budding with alternate bithecae (Fig. 8D, E). Branching is often irregular and secondary connections between stipes through dissepiments and anastomosis is common, but not present in all taxa.

Planktic dendroids (Kraft \& Kraft 2008) have been described from a number of occurrences. They may possibly be referred to the genus Calyxdendrum Kozłowski, a genus that Bulman (1970) identified as a member of the planktic Anisograptidae. The taxon Pseudocallograptus cf. salteri (Skevington 1963) from the Middle Ordovician of Öland has a sicula with a free nema, indicating a possibly planktic taxon. These planktic taxa should not be placed in the planktic Graptoloidea, as they likely represent a secondary, independent origination of a planktic life style. It is preferred here to keep them with the benthic Dendrograptidae, as they do not possess the defining characters of the planktic Anisograptidae. They may have to be referred to their own family when better known.

Family Acanthograptidae Bulman, 1938 (p. 20)

(= Inocaulidae Ruedemann, 1947, p. 230)

Diagnosis (emended). - Benthic graptoloids with variable shape of colonies, from erect, bushy or fan-shaped; thecae elongated, tube-shaped with a non-serial organisation; complex stipe development of ropy appearance and isolated autothecal apertures or development of twigs; regularly placed bithecae based on a triad budding concept, but no size differentiation of bithecae; anastomosis or dissepiments present in some taxa; sicular development largely unknown.

Genera included. - Acanthograpsus Spencer, 1878; Archaeodictyota Obut \& Sobolevskaya, 1967; Boiophyton Obrhel, 1959; Coremagraptus Bulman, 1942; Koremagraptus Bulman, 1927b (Fig. 8E); Palaeodictyota Whitfield, 1902; Saxonia Roselt, 1962; Trimerohydra Kozłowski, 1959.

Discussion. - Rickards \& Durman (2006, fig. 18) included a number of taxa of the Acanthograptidae in their study (Acanthograptus, Thallograptus, Koremagraptus, Palaeodictyota) and showed them as a monophyletic group. The presence of multiserial stipes was regarded as the main synapomorphy of the group. The monophyly of the taxon cannot be proven due to the lack of structural information on most taxa and the family is therefore regarded as a preliminary taxonomic unit until more details on the colony development of its members are available. The family includes a small number of taxa with complex stipe development and tubular thecae with isolated apertures (Fig. 5D). The proximal development and sicula are unknown for all included taxa. A number of taxa previously included in the Inocaulidae may turn out to represent algae, including the type species of the genus Inocaulis, Inocaulis plumulosa Hall.

Maletz \& Kozłowska (2013) illustrated partial relief specimens of Acanthograptus sinensis Hsü \& Ma, with slender and parallel-sided, tube-like thecae, typical of Acanthograptidae. The specimens show paired thecal origins, but a differentiation of potential autothecae and bithecae is impossible. The thecae are generally straight and curve outwards only at their apertures, but a number of thecae can be seen to produce irregular curved paths.

Acanthograptidae can easily be misidentified as landplants if only the outline of the specimens is preserved. This may be the case with the genera Boiophyton and Saxonia, two poorly known acanthograptid genera from Ordovican to Silurian strata. Kenrick et al. (1999) have convincingly documented the graptolitic relationships of Boiophyton. 
Ruedemann (1947) introduced the family Inocaulidae for taxa with complex stipes formed from numerous slender tubular thecae. Mierzejewski (1986) discussed the genus Inocaulis in some detail and questioned the inclusion in the graptolites. He restricted the family Inocaulidae to a single genus, Inocaulis. Muir et al. (2013) referred a single stipe fragment from the Middle Ordovician of Guizhou, China to the genus Inocaulis, and suggested the recognition of Inocaulis as a graptolite. There is no evidence of a graptolitic nature of the type Inocaulis plumulosa Hall, 1852, however, and the inclusion of Inocaulis in the graptolite must be questioned. The specimen of Muir et al. (2013) may be identified as a taxon of the Acanthograptidae.

Family Mastigograptidae Bates \& Urbanek, 2002 (p. 458)

Diagnosis (emended). - Bushy dendroid colonies with slender stipes formed from stolonal strands; metathecae arranged in pairs, distinctly widening; fuselli formed as complete fusellar rings with irregularly placed sutures, not regular half-rings; triad budding present; auto- and bithecae not differentiated by size; sicular development poorly known.

Genera included. - Mastigograptus Ruedemann, 1908; Micrograptus Eisenack, 1974

Discussion. - Mastigograptidae is likely to be monophyletic. The family is based on two closely related genera with a typical triad budding system. The taxa are known from isolated three-dimensionally preserved specimens, found in glacial boulders in northern Germany and Poland. Their origin and phylogenetic relationships are uncertain, but the development of a typical triad budding system demands an inclusion in the derived Eugraptolithina (see Mitchell et al. 2013), and here in Dendroidea. Rickards \& Durman (2006), however, included Mastigograptus in Dithecoidea.

Mastigograptidae differ from all other graptolites through their slender stems with a tightly adhering tube covering the stolon system and the thin-walled distinctly widening and completely isolated metathecal tubes (Fig. 8F). Similarities can be seen only to Dithecodendridae, but isolated material is not available from the latter group. This small, but well-defined family shows clearly the difficulties in our taxonomy. Few taxa are well enough known for a detailed analysis. Bates \& Urbanek (2002) introduced a new order, Mastigograptida, for these taxa.

Bates \& Urbanek (2002) provided some general information on the "initial segment" of the Mastigograptus colonies, which they presumed to represent the sicula. However, details of the sicular development are not available due to the cortical overgrowth of the proximal ends and the presence of a prosicula and metasicula is unknown. The authors interpreted the structure as a cylindrical sicula similar to the sicula of the dendroid graptolites, different from the embryonic vesicle of Rhabdopleura or the conical sicula of Dendrotubus.

Order Graptoloidea Lapworth, 1875 in Hopkinson

\& Lapworth (1875) (p. 633)

(= Rhabdophora Allman, 1872, p. 380;

= Division Graptoloida Mitchell et al., 2013, p. 53)

Definition. - (Mitchell et al. 2013, p. 53: Division Graptoloida) Graptoloida is the total clade descended from the first graptolite to possess a sicula with a caudal apex.

Discussion. - The Graptoloidea may be diagnosed as nematophorous graptoloids with serially budded autothecae and triad budding or derived development. They have highly variable colony shapes and are generally symmetrically organized. Their thecal construction varies from simple to complex. Graptoloidea (Graptoloida in Maletz et al. 2009 and Mitchell et al. 2013) represents a monophyletic taxon. Graptoloidea (Figs 2, 5) is used here in the same sense as in Fortey \& Cooper (1986), to include all planktic, "nematophorous" graptoloids or Graptoloida of Maletz et al. (2009, p. 9) and Mitchell et al. (2013), while Bulman (1955, 1970) excluded Anisograptidae from Graptoloidea and referred the family to Dendroidea. Due to the complexities in colony development and its rapid evolutionary changes, a characterization of Graptoloidea is difficult to provide. Limitation of the colony shape is due to the planktic lifestyle of the organisms and their clonal, colonial organization. Early taxa (Rhabdinopora Eichwald) closely resemble benthic taxa (Dictyonema Hall), but new colony shapes and developments quickly evolved after the origin of the planktic graptoloids in the basal Tremadocian.

Secondarily derived planktic taxa of the Dendroidea have been discussed earlier (see Dendrograptidae). As long as information on the development of their siculae and proximal development is not available, a comparison with the Graptoloidea is impossible and the interpretation of these taxa as independently derived may be conjectural.

The Supercohort Eugraptoloida Maletz, Carlucci \& Mitchell, 2009, p. 11 (= Graptoloidea sensu Bulman, 1970). - Maletz et al. (2009, p. 11) defined the clade Eugraptoloida as the common ancestor of Nicholsonograptus fasciculatus Nicholson and Exigraptus uniformis $\mathrm{Mu}$ in $\mathrm{Mu}$ et al. and all its descendents. The authors indicated as a defining synapomorphy the loss of the bithecae along the stipes (synapomorphy 2). Eugraptoloida, thus, include the same group of taxa included in the order Graptoloidea by Bulman $(1955,1970)$. Interestingly, 

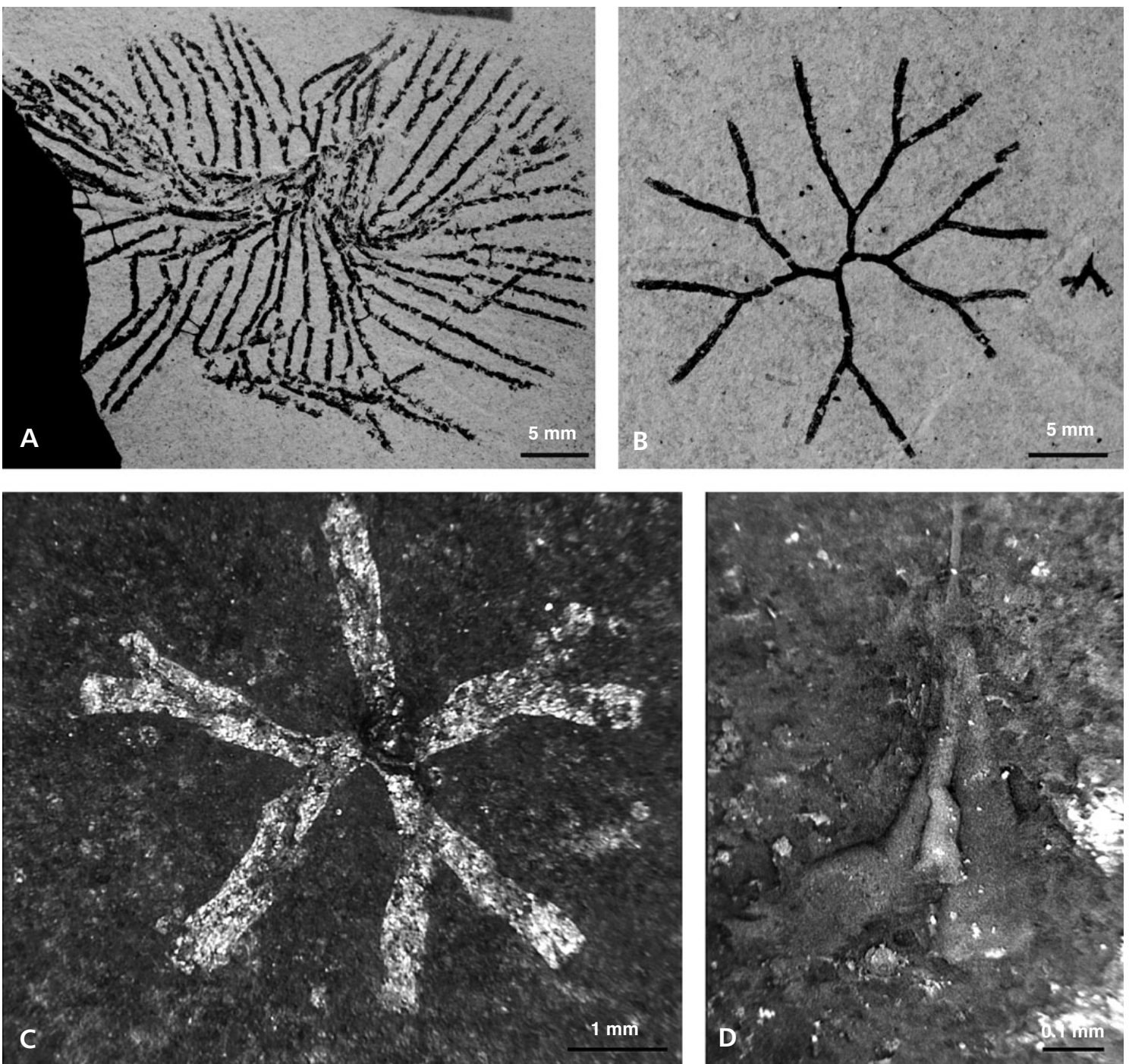

Figure 9. Examples of Anisograptidae, showing rhabdosome shapes and development. $\bullet$ A - Rhabdinopora flabelliformis anglica Bulman, Erdtmann collection, specimen showing conical shape of rhabdosome and presence of dissepiments connecting stipes. $\bullet$ B - Anisograptus matanensis Bulman, Erdtmann collection, horizontal, triradiate taxon, see juvenile to the right. $\bullet$ C - Staurograptus dichotomous Emmons, NYSM 6016 (Ruedemann 1904 , pl. 2, fig. 9), small specimen with impression of sicula in centre. $\bullet$ D - Staurograptus dichotomous Emmons, NYSM 6011, latex cast of juvenile showing sicular bitheca (Ruedemann 1904, pl. 2, fig. 4).

the cladistic analysis of Fortey \& Cooper (1986, fig. 3) showed Graptoloidea sensu Bulman (1970) as polyphyletic, a notion that has never been rejected entirely, but was not discussed in Maletz et al. (2009). Fortey \& Cooper (1986) analyzed the anisograptids in aim to understand the transition of the bithecate to non-bithecate taxa. Thus, their analysis was able to shed some light on the roots of the non-bithecate graptoloids (now the Eugraptoloida). The conclusion shows an at least triphyletic origin of nonbithecate graptoloids and the authors concluded that an inclusion of the Anisograptidae in the Graptoloidea was more useful.

Lindholm (1991, p. 289), also discussing the finds of Williams \& Stevens (1991), suggested a loss of bithecae "along different lineages in a rather restricted time period" within the anisograptids, based on the investigation of the late Tremadocian Hunnegraptus copiosus Biozone fauna. Lindholm (1991) included the genus Hunnegraptus Lindholm, in which the sicular bitheca is the only bitheca of the colony, in the Dichograptidae and referred Paradelograptus Erdtmann, Maletz \& Gutiérrez-Marco to the Sinograptidae.

Maletz et al. (2009) used Rhabdinopora Eichwald as the outgroup and added two further anisograptid taxa (Anisograptus Ruedemann, Adelograptus Bulman) to their analysis. Due to the low number of anisograptid taxa, the authors were unable to trace the origins of the Eugraptoloida. However, their intention was to differentiate clades within the Eugraptoloida and not to find the eugraptoloid roots. 
The value of the clade Eugraptoloida (see Fig. 2) is questionable, as the transition from the bithecate to the non-bithecate graptolites is still not resolved. The main difficulty in understanding these early planktic graptoloids and their evolutionary relationships is the rarity of well-preserved and isolatable material or relief specimens showing the thecal details of the transitional taxa (Lindholm 1991). Sadler et al. (2011, fig. 13) showed a crisis in graptolite evolution during the Tremadocian, in which an extremely low diversity has been demonstrated. This "crisis", however, may be based on the lack of sections of this age, which contain well-preserved or investigated graptolite faunas, and thus may be an artefact. The sudden appearance of Sinograpta and Dichograptina in the basal Floian (and possibly in the upper Tremadocian) indicates an independent origin of at least these two groups from Anisograptidae.

Suborder Graptodendroidina Mu \& Lin, 1981 in Lin (1981) (p. 244)

Diagnosis. - See diagnosis of family Anisograptidae.

Discussion. - Lin (1981) introduced the Graptodendroidina to accommodate the bithecate planktic graptoloids of the Anisograptidae. Mu (1974, p. 229), previously, used the term "graptodendroids" for the Anisograptidae, but referred the taxon to the Dendroidea. Erdtmann (1988) emended the Graptodendroidina and discussed its early members in some detail. The Graptodendrodina is here understood as a paraphyletic taxon from which all derived graptoloids originate.

Family Anisograptidae Bulman, 1950 (p. 79)

Diagnosis (emended). - Planktic, multiramous graptoloids with triad budding; colony shape reclined, horizontal to declined and bell-shaped; origin of first theca in the median part of the prosicula; proximal development isograptid, quadriradiate to biradiate, variably dextral and sinistral; distinct size differentiation of autothecae and bithecae; bithecae initially regular, irregular and often reduced or even lost in later taxa; autothecae simple, aperturally widening tubes, sometimes aperturally isolated; ventral rutelli common; dissepiments in a few taxa.

Genera included. - Adelograptus Bulman, 1941; Aletograptus Obut \& Sobolevskaya, 1962; Ancoragraptus Jackson \& Lenz, 2003; Anisograptus Ruedemann, 1937 (Figs 9B, 11B); Aorograptus Williams \& Stevens, 1991; Araneograptus Erdtmann \& VandenBerg, 1985; Bryograptus Lapworth, 1880; Chigraptus Jackson \& Lenz, 1999; Choristograptus Legrand, 1964; Damesograptus Jahn, 1892; Dictyodendron Westergård, 1909; Dictyograptus
Hopkinson, 1875 in Hopkinson \& Lapworth (1875); Dictyograptus Westergård, 1909; Diphygraptus Zhao \& Zhang, 1985; Graptopora Salter, 1858; Heterograptus Zhao \& Zhang in Lin, 1986; Holopsigraptus Zhao \& Zhang, 1985; Hunjiangograptus Zhao \& Zhang, 1985; Hunnegraptus Lindholm, 1991; Kiaerograptus Spjeldnaes, 1963; Muenzhigraptus Zhao \& Zhang, 1985; Neoclonograptus Zhao \& Zhang, 1985; ?Nephelograptus Ruedemann, 1947; Paraclonograptus Zhao \& Zhang, 1985; Paratemnograptus Williams \& Stevens, 1991; Phyllograpta Angelin, 1854; Psigraptus Jackson, 1967; Radiograptus Bulman, 1950; Rhabdinopora Eichwald, 1855 (Fig. 5A, 9A); Sagenograptus Obut \& Sobolevskaya, 1962 [non Sagenograptus Lenz \& Kozłowska-Dawidziuk, 2001: see Retiolitidae], Staurograpsus Emmons, 1855 (Fig. 9C); ?Stellatograptus Erdtmann, 1967; Toyenograptus Li, 1984; Triograptus Monsen, 1925; Triramograptus Erdtmann, 1998 in Cooper et al. (1998); Yukonograptus Lin, 1981.

Discussion. - Anisograptidae is a paraphyletic family at the origin of the Graptoloidea. Mitchell et al. (2013) regarded the genera Rhabdinopora and Anisograptus as basal Graptoloidea, but did not discuss derived graptoloid taxonomy. Maletz et al. (2009) identified the Anisograptidae as stem eugraptoloids.

The internal evolutionary structure of the Anisograptidae has never been analysed in detail and the origins of the derived Dichograptina and Sinograpta are uncertain. It is possible that a number of clades originated independently from the Anisograptidae. Mu (1974) named the Anisograptidae informally as the "graptodendroids", but Graptodendroidina Mu \& Lin (in Lin 1981, pp. 244-245) was introduced as a suborder of Dendroidea. It was used by a number of authors (e.g. Erdtman 1988, Wang \& Wang 2001, Cho et al. 2009).

The proximal development and rhabdosome construction is known from a surprisingly high number of anisograptid taxa. The development of the earliest taxa is quadriradiate (Fig. 9C) with four stipes originating in close succession from the initial theca (th $1^{1}$ ), but tri- (Fig. 9B) and biradiate (Fig. 10A, F) taxa soon take over (Maletz 1992). Anisograptidae generally bear alternate bithecae associated with the autothecae on all stipes, of which the sicular bitheca (Figs 9D, 10B, F) is the earliest and is probably the last bitheca lost through the evolutionary elimination of the bithecae during the late Tremadocian (Lindholm 1991).

Suborder Sinograpta Maletz, Carlucci \& Mitchell, 2009 (p. 11) (ex Pan-Sinograpta Maletz, Carlucci \& Mitchell, 2009)

Definition. - (Maletz et al. 2009, p. 11) The crown clade Sinograpta comprises the common ancestor of Nicholsonograptus fasciculatus and the first species with a slender sicula and parallel-sided prosicula and all its descendants. 

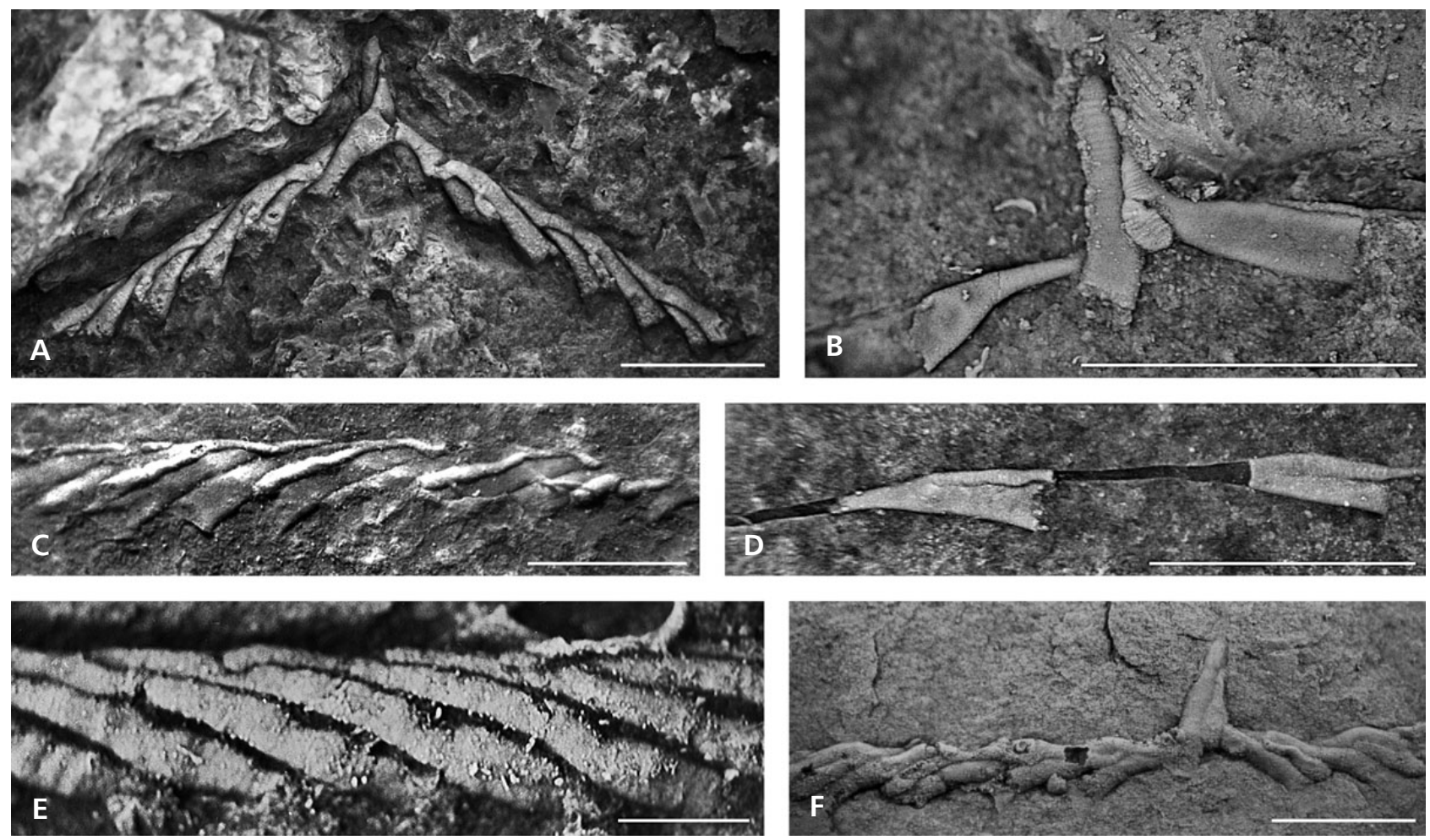

Figure 10. Transitional anisograptids with and without bithecae. • A, F - "Kiaerograptus" supremus Lindholm, LO 5970T, holotype in reverse view with regular bithecae, (A) and PMO 139.919, specimen in obverse view (F) showing irregularly placed bithecae and more horizontal colony shape. - B, D - Paradelograptus onubensis Erdtmann, Maletz \& Gutiérrez-Marco, GSC 118739, obverse view, showing large sicular bitheca and helical line in prosicula, (B), GSC 118751, stipe without bithecae (D). • C - Kiaerograptus kiaeri Monsen, PMO 72.833, fragment with long, regularly positioned bithecae on stipe. $\bullet$ E - Paratemnograptus sp., PMO 108.558, fragment with plaited overlap of thecae (lateral thecal origination), but no bithecae (see Lindholm \& Maletz 1989). Scale bar represents $1 \mathrm{~mm}$.

Discussion. - Sinograpta may be characterised by multiramous to two-stiped, horizontal to pendent rhabdosomes. The colony is biradiate with asymmetrical placing of first order stipes, a nearly parallel-sided sicula with parallelsided prosicula. The origin of the first theca is in the median part of prosicula in early taxa, but in the lower part of the prosicula in younger ones. The thecae are simple or with complex and elaborate apertures, slender and sometimes elongated. At least a sicular bitheca is present in early members (Fig. 10B).

Sinograpta is defined as a monophyletic taxon (Maletz et al. 2009), as sister group to the Pan-Reclinata, including a number of family level taxa. Maletz et al. (2009) introduced the cohort Pan-Sinograpta for the taxa previously known as the families Sinograptidae and Sigmagraptidae (Fortey \& Cooper 1986). Maletz et al. (2009) recognized the cohort Pan-Sinograpta as a stem group to the subcohort Sinograpta, but stated that all taxa in their analysis can be referred to the Sinograpta. Early species of Paradelograptus show a sicular bitheca (Fig. 10B), but the stipes show simple thecae with dorsal origins (Fig. 10D). Unfortunately, very few graptolites from the upper Tremadocian show details of their rhabdosome development and thus little can be learnt about their evolutionary relationships.
The taxon is here called Sinograpta and differentiated into three families, Sigmagraptidae, the derived Sinograptidae and Abrograptidae of uncertain relationships. The analysis of Maletz et al. (2009) provided no resolution within the Pan-Sinograpta, but showed an unresolved polytomy at the base of the unit. A differentiation of Sinograptidae and Sigmagraptidae is possible, based on structural details of the proximal ends (Fig. 11).

The proximal asymmetry (Fig. 11A, C) of the stipe divergence in the Sigmagraptidae is retained as a symplesiomorphic character from the Anisograptidae (Fig. 11B), but the sicula is now positioned vertically to the stipes. The proximal end changed to a symmetrical development in the Sinograptidae (Fig. 11D, E). The stratigraphical distribution of the taxa indicates an origin of Sinograptidae from Sigmagraptidae in the late Dapingian to early Darriwilian.

Family Sigmagraptidae Cooper \& Fortey, 1982 (p. 257) (ex Sigmagraptinae Cooper \& Fortey, 1982, p. 257)

Diagnosis (emended). - Multiramous to one-stiped, horizontal to pendent rhabdosomes; colony biradiate with asymmetrical placing of first order stipes; sicula 


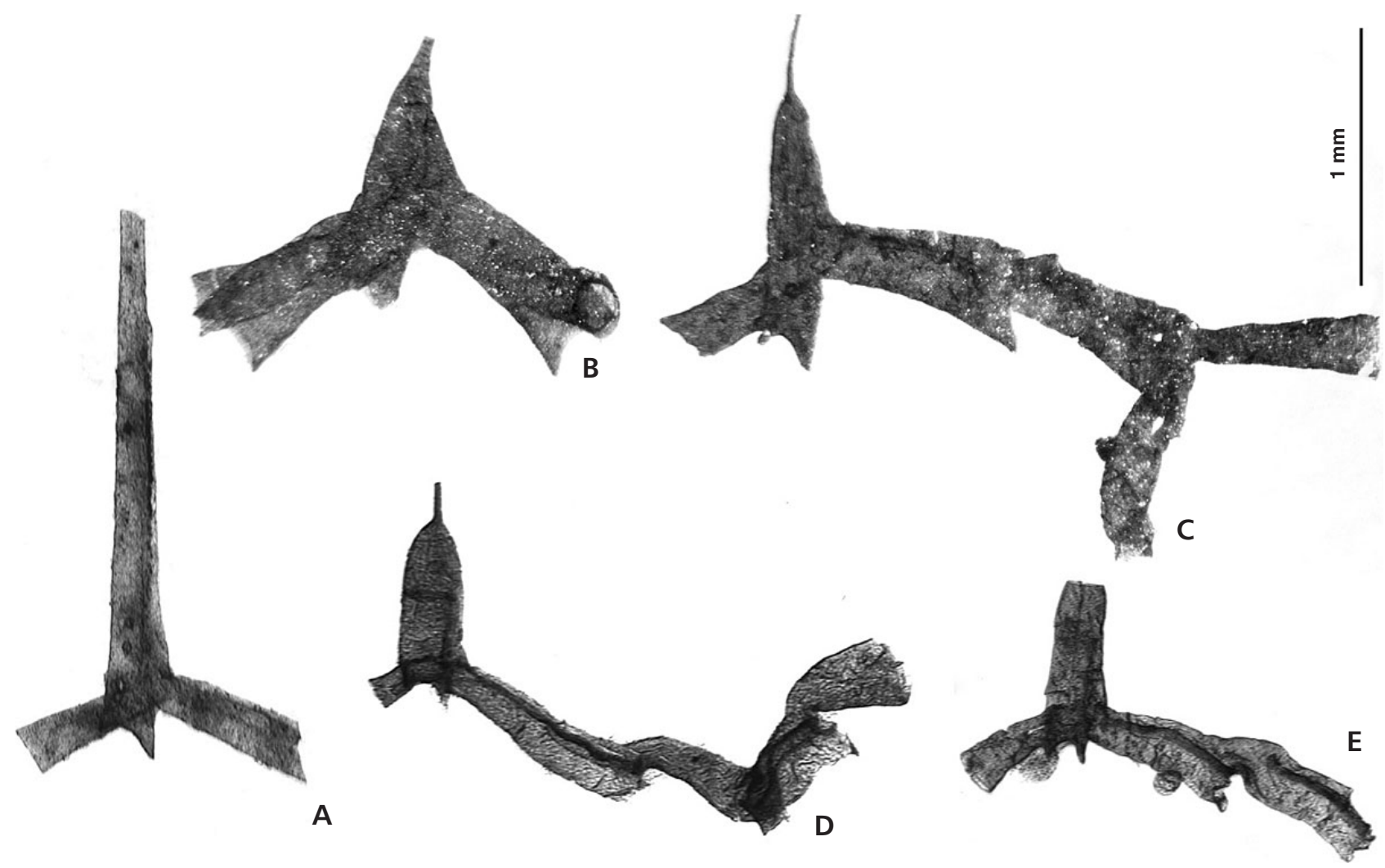

Figure 11. Anisograptidae (B) and Sinograpta (A, C-E), proximal shapes, Sigmagraptidae (A, C) with asymmetrical development and Sinograptidae (D, E) with symmetrical development of stipes. • A - Sigmagraptus sp. with elongated, slender sicula, CHN 11.4E. • B - Anisograptus matanensis Ruedemann, NGPA 216/07. • C - Sigmagraptine indet., SPI 63. D - Anomalograptus reliquus Clark, WB2.34.42b. • E - Holmograptus sp., cf. Holmograptus lentus Törnquist, SPSE 4/03c. All specimens flattened, from Cow Head Group, western Newfoundland. Scale bar represents $1 \mathrm{~mm}$.

parallel-sided with parallel-sided prosicula; origin of first theca in median part of prosicula in early taxa, in the lower part of the prosicula in younger ones; thecae simple or with complex and elaborate apertures, slender and sometimes elongated.

Genera included. - Acrograptus Tzaj, 1969; Azygograptus Nicholson \& Lapworth, 1875 in Nicholson (1875); Eoazygograptus Obut \& Sennikov, 1984; Eotetragraptus Bouček \& Přibyl, 1951; Etagraptus Ruedemann, 1904; Goniograptus M'Coy, 1876; Hemigoniograptus Jin \& Wang, 1977; Jiangnanograptus Xiao \& Chen, 1990; Jishougraptus Ge, 1988; Keblograptus Riva, 1992; Kinnegraptus Skoglund, 1961; Laxograptus Cooper \& Fortey, 1982; Maeandrograptus Moberg, 1892; Metazygograptus Obut \& Sennikov, 1984; Oslograptus Jaanusson, 1965; Paradelograptus Erdtmann, Maletz \& Gutiérrez-Marco, 1987; Paraulograptus Bouček, 1973; Pendeosalicograptus Jiao, 1981; Perissograptus Williams \& Stevens, 1988; Praegoniograptus Rickards \& Chapman, 1991; Prokinnegraptus Mu, 1974; Sigmagraptus Ruedemann, 1904 (Fig. 11A); Taishanograptus Li \& Ge, 1987 in Li, Ge \& Chen (1987); Trichograptus Nicholson, 1876; Wuninograptus Ni, 1981; Yushanograptus Chen, Sun \& Han, 1964.
Discussion. - Sigmagraptidae is a paraphyletic family from which Sinograptidae originated in the late Dapingian to early Darriwilian. Sigmagraptidae is used here at family level, following Fortey \& Cooper (1986), as it includes a fairly large group of taxa. Alternatively, Sinograptidae could be kept as a family with the subfamilies Sinograptinae, Sigmagraptinae and Abrograptinae. Sigmagraptidae can be differentiated from Sinograptidae through the presence of an asymmetrical proximal end with the stipes of the first order originating at different levels from the sicula, a plesiomorphic character retained from the Anisograptidae (Fig. 11). Sigmagraptidae have the sicula placed vertically between the stipes (Maletz et al. 2009, p. 11: synapomorphy 3 ) instead of possessing the inclined sicula of the Anisograptidae.

Maletz et al. (2009) showed Maeandrograptus leptograptoides Monsen as most closely related to Holmograptus Kozłowski, Pseudodichograptus Chu and Nicholsonograptus Bouček \& Přibyl, but Maletz (2004) already referred the genus Maeandrograptus to the sigmagraptines, based on the proximal development with the asymmetrical development of the crossing canals.

Strangely, Perissograptus, closely related to Maeandrograptus, is shown as a member of Tetragraptidae in 
Maletz et al. (2009). Perissograptus has a sicula identical in shape and development to Maeandrograptus, being typically slender and parallel-sided with slight development of a dorsal and a ventral rutellum. The proximal development differs considerably from the development in the tetragraptids and of Phyllograptus Hall, with which it was connected by Maletz et al. (2009, fig. 2). The tetragraptids and phyllograptids possess a small prosicula and a distinctly widening metasicula and wide crossing canals. Phyllograptus also has a dorsal virgellar spine, not present in Perissograptus. A closer relationship of Perissograptus to the Tetragraptidae, as suggested by Maletz et al. (2009), therefore is unlikely.

The genus Acrograptus, referred to the stem reclinatids in a group with taxa identified herein as Pterograptidae by Maletz et al. (2009), is identified as a sigmagraptine through the proximal development of Acrograptus specimens from the Table Head Group of western Newfoundland (Albani et al. 2001). The genus has been used to include slender two-stiped graptoloids often of uncertain relationships. The identity of the species used by Maletz et $a l$. (2009) for their analysis is unknown as no further data are provided. The clade including Acrograptus in Maletz et al. (2009) can be identified as the Pterograptidae, once Acrograptus is removed.

The inclusion of the one-stiped genera Azygograptus and Jishougraptus is based on the development of the sicula with a parallel-sided prosicula and a low prosicular origin of th $1^{1}$ in a number of chemically isolated specimens from the Dapingian (Chewtonian in Australasian stratigraphy) of western Newfoundland (Maletz 2004). Azygograptus specimens show a dimensionally identical sicula, even though the prosicula cannot be differentiated in any of the known material, as isolated specimens have never been found. "Azygograptus" validus (Cymatograptus validus Törnquist herein) from the Lower Floian of Scandinavia and Britain (Törnquist 1901, Beckly \& Maletz 1991) may not be related to Azygograptus, but can be interpreted as a one-stiped member of the dichograptid genus Cymatograptus Jaanusson. It differs from all other Azygograptus species in possessing a long, slowly widening sicula with a high, possibly prosicular origin of the first theca. The development is identical to that of Cymatograptus undulatus Törnquist, but the species lacks the second stipe.

Family Sinograptidae Mu, 1957 (p. 387)

Diagnosis (emended). - Multiramous to two-stiped, horizontal to declined rhabdosomes; colony biradiate with symmetrical placing of first order stipes; sicula parallelsided, often with dorsal and ventral rutellum; parallel-sided prosicula; thecae simple or with complex and elaborate apertures, slender and sometimes elongated, often with prothecal folding.
Genera included. - Allograptus Mu, 1957; Anomalograptus Clark, 1924 (Fig. 11D); Atopograptus Harris, 1926; Brachiograptus Harris \& Keble, 1932; Hemiholmograptus Hsü \& Chao, 1976; Holmograptus Kozłowski, 1954 (Fig. 11E); Nicholsonograptus Bouček \& Přibyl, 1951; Paradidymograptus Mu, Geh \& Yin, 1962 in Mu et al. (1962); Pseudodichograptus Chu, 1965; Pseudojanograptus Hsü \& Chao, 1976; Pseudologanograptus Hsü \& Chao, 1976; Pseudotetragraptus Hsü \& Chao, 1976; Sinazygograptus Wang \& Wu, 1977 in Wang \& Jin (1977); Sinograptus Mu, 1957; Tylograptus Mu, 1957; Zygograptus Harris \& Thomas, 1941.

Discussion. - Sinograptidae is a monophyletic family including a number of genera united by their proximal development and thecal style. Sinograptidae possess a vertical, parallel-sided sicula with a comparatively large, parallelsided prosicula (Fig. 11D), a dorsal and a ventral rutellum on the sicula and symmetrically placed stipes. Most sinograptids also have pronounced prothecal folds and further thecal elaborations. They represent a short-lived, but successful group of multiramous to biramous graptoloids in the early Darriwilian. The youngest member occurs in the Nicholsonograptus fasciculatus Biozone of mid-Darriwilian age.

Family Abrograptidae Mu, 1958 (p. 261)

(p. 264; English text)

Diagnosis. - Biradiate, multiramous to biserial or unibiserial Sinograpta with reduced fusellum and lists showing the thecal outlines; sicula completely sclerotized.

Genera included. - Abrograptus Mu, 1958; Dinemagraptus Kozłowski, 1951; Jiangshanites Mu \& Qiao, 1962; Metabrograptus Strachan, 1990; Parabrograptus Mu \& Qiao, 1962.

Discussion. - Little information exists on the constructional details of the family Abrograptidae. The recognition of the members of the family is based on the reduction of the thickness of the fusellum. Isolated material referred to Jiangshanites (Maletz 1993) indicates a relationship to Sinograpta. Abrograptids are usually found as poorly preserved flattened specimens in shale. A few chemically isolated proximal ends of Jiangshanites dubius (Maletz, 1993) represent the only isolated material available. The specimens show a symmetrical development of the first order stipes of the multiramous colony and a small, parallel-sided sicula with a prominent rutellum and a prosicular origin of th $1^{1}$. Finney (1980) included Reteograptus Hall in Abrograptidae, but the isolated specimens of that taxon indicate an axonophoran origin due to the presence of a prominent ventral virgellar spine (Finney 1980, 
fig. 16). It is here preliminarily referred to Climacograptidae based on the lack of proximal spines and the bulbously widened thecae without intrathecal folds. The single isolated specimen of Dinemagraptus warkae (Kozłowski 1951) shows a small sicula with a proportionally long prosicula, but little further detail is available. The sicular aperture bears a rutellum or a short virgellar spine. The thecae are outlined by a possibly dorsal list and an apertural ring.

Sinograpta indet. - Thamnograptus Hall, 1859.

Discussion. - Thamnograptus is a dubious multiramous genus the proximal end of which is unknown. Finney (1980) indicated a biform development of the thecae with spined slender proximal thecae and distal dichograptid thecae, but this is not supported from additional and better-preserved material. The association as fragmented specimens on shale surfaces may be adventitious and a proof of the biform thecal development may only be possible through chemically isolated material. The dichograptid thecal part could also represent remains of the associated Acrograptus species. The janograptid fragment (Finney 1980, fig. 4B) may belong to the taxon identified as Didymograptus sp. cf. D. serratulus Hall, more likely representing an Acrograptus species. Similar janograptid specimens are found as chemically isolated material in western Newfoundland (Albani et al. 2001). Thamnograptus is restricted to the Middle Ordovician (Upper Darriwilian to Sandbian).

Suborder Dichograptina Lapworth, 1873b

(table 1, facing p. 555)

[ex Dichograptidae Lapworth, 1873b]

[syn. Didymograptina Lapworth, 1880, p. 192

nom. correct. Jaanusson, 1960, p. 309;

ex Didymograpta Lapworth, 1880]

Diagnosis (emended). - Multiramous to two-stiped graptoloids with biradiate isograptid proximal development and maeandrograptid symmetry; colony shape scandent to reclined, horizontal and even pendent; prosicula small, with widening and much larger metasicula; thecae simple, widening tubes with or without rutellum; branching dichotomous or cladial.

Discussion. - Maletz et al. (2009) defined the total clade Pan-Reclinata (Dichograptina plus all derived taxa) to comprise all species that share a more recent common ancestor with Exigraptus uniformis $\mathrm{Mu}$ in $\mathrm{Mu}$ et al. than with Nicholsonograptus fasciculatus Nicholson, easily separated from its sister group, Pan-Sinograpta through the symmetrical proximal end. Their analysis showed only very low resolution within the stem lineage of the group (Fig. 2). Pan-Reclinata is a cladistically valid taxon to describe all dichograptids and derived taxa as a monophyletic clade. It is not used as it would add an unnecessary level in the taxonomic hierarchy used herein.

Dichograptina is a paraphyletic unit with a poor internal resolution (Fig. 2) in need of a more detailed investigation of its members. Dichograptina in this context includes the stem-reclinatids and the Pan-Tetragrapta of Maletz et al. (2009, fig. 2) and is largely consistent with the designation of Dichograptina by Lapworth (1873b), except that Sinograpta (Sinograptidae and Sigmagraptidae) were not differentiated at that time and only Fortey \& Cooper (1986) recognized the necessity of separating these taxa. The large group of stem reclinatids and the uncertain taxonomic differentiation within the group by Maletz et al. (2009) indicates a lack in resolution and understanding of these taxa. Four families are tentatively differentiated in Dichograptina. Based on proximal development and rhabdosome construction, Didymograptidae and Pterograptidae can easily be differentiated, but the basal taxa, the Dichograptidae are less well known. Tetragraptidae is the most diverse group in rhabdosome development, including pendent to reclined and scandent taxa. The proximal development of the Tetragraptidae (Fig. 12B) indicates a most probable origin through a multiramous member of the Dichograptidae that lost its capacity of developing distal dichotomies beyond the first one, as it is basically identical to the development in Clonograptus Nicholson (see Lindholm \& Maletz 1989).

Family Dichograptidae Lapworth, 1873b (p. 555) [incl. Schizograptinae Ge in Mu et al. 2002, p. 201; Mimograptinae Ge in Mu et al. 2002, p. 316]

Diagnosis (emended). - Multiramous graptoloids with biradiate proximal development and symmetrically placed crossing canals; colony shape reclined to horizontal and declined; prosicula small, with widening and much larger, conical metasicula; proximal development of the isograptid type; thecae simple, widening tubes without a distinct rutellum; branching dichotomous.

Genera included. - Anthograptus Törnquist, 1904; Calamograptus Clark, 1924; Clonograpsus Nicholson, 1873 (Fig. 12A, C, D, F); Ctenograptus Nicholson, 1876; Dichograpsus Salter, 1863; Hermannograptus Monsen, 1937; Holograptus Holm, 1881a; Kellamograptus Rickards \& Chapman, 1991; Kstaugraptus Tzaj, 1973; Loganograptus Hall, 1868 (Fig. 12E); Mimograptus Harris \& Thomas, 1940 (non Mimograptus Lapworth in Elles \& Wood, 1908: see Glossograptidae); Orthodichograptus Thomas, 1972; Rouvilligraptus Barrois, 1893; Schizograp- 

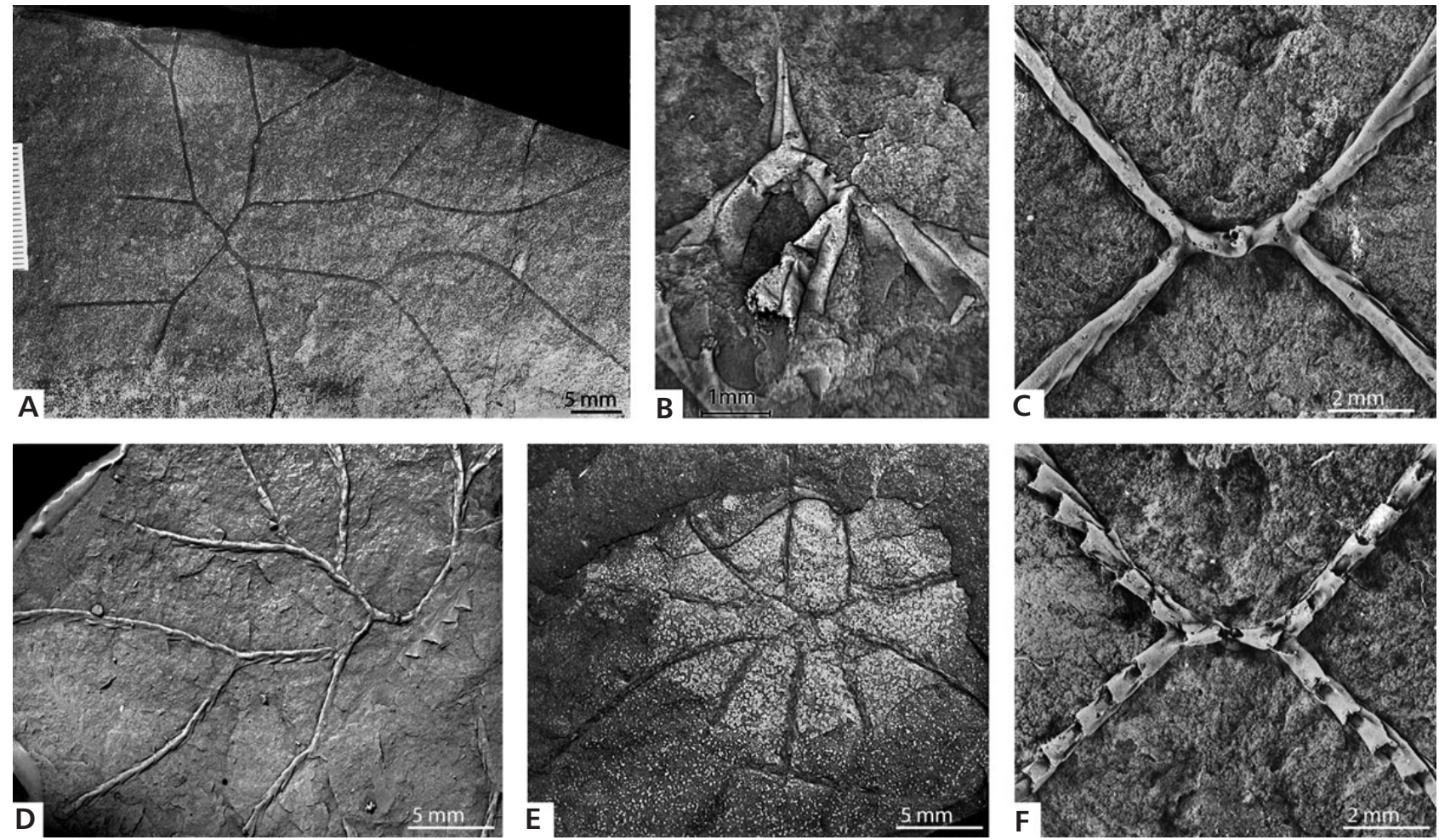

Figure 12. Dichograptina. • A, C, F - Clonograptus multiplex (Nicholson), LO 6027t (counterparts), Sweden, Hunneberg. Flattened specimen (A) and proximal ends preserved in relief in dorsal $(\mathrm{C})$ and ventral $(\mathrm{F})$ views, showing thecae and tetragraptid development, sicula visible in centre. - B - Tetragraptus amii Elles \& Wood, JM Di 7, proximal end in relief showing isograptid proximal development with tetragraptid proximal end (th ${ }^{1}$ and th $3^{2}$ dicalycal; only dichotomy one seen) in reverse view. $\bullet$ D - Clonograptus sp. cf. Clonograptus flexilis (Hall), dorsal view in relief, showing some details of thecae. $\bullet$ E - Loganograptus logani Hall, flattened specimen with extensive webbing. Scale bar represents $1 \mathrm{~mm}$

tus Nicholson, 1876; Temnograptus Nicholson, 1876; Triaenograptus Hall, 1914; Tridensigraptus Zhao, 1964; Trochograptus Holm, 1881a.

Discussion. - Dichograptidae is most probably a paraphyletic taxonomic unit, but internal differentiation is impossible due to lack of information on structural details. Tetragraptidae and Didymograptidae may have originated independently from Dichograptidae. Dichograptidae includes all of the multiramous Lower Ordovician taxa (Fig. 12A, C-F) related to Clonograptus, e.g. multiramous taxa with dichotomous to lateral branching. They are usually based on a tetragraptid proximal end with two first order stipes (Fig. 12C, F) and symmetrically placed crossing canals (Fig. 12B). The proximal end and development are known from isolated and relief specimens of Clonograptus (Lindholm \& Maletz 1989), but are unknown from all other dichograptids. Isolated material does not exist of most of the taxa and differentiation of genera is based on colony shape and placement/orientation of stipes. Initially two-stiped taxa with distal branchings like Mimograptus and Kstaugraptus are also included, as their proximal development appears to be identical to that of the remaining Dichograptidae.
Family Didymograptidae Mu, 1950 (p. 180)

(emend. Mu et al. 2002, p. 228)

Diagnosis (emended). - Two-stiped, pendent to horizontal, reclined, reflexed and deflexed graptoloids; sicula conical, widening distinctly towards the aperture, with small prosicula; proximal development isograptid or more rarely of artus type in derived taxa; thecae simple, widening tubes with or without rutellum; rarely complex or with prothecal folding in derived taxa.

Genera included. - Aulograptus Skevington, 1965; Baltograptus Maletz, 1994 (Fig. 13B, F); Cladograpsus Geinitz, 1852 (non Cladograpsus Carruthers, 1858: see Dicranograptinae); Cymatograptus Jaanusson, 1965 (Fig. 13D); Didymograpsus M'Coy, 1851 in Sedgwick \& M'Coy (1851) (Fig. 13E); Expansograptus Bouček \& Přibyl, 1951 (Fig. 13A, C, G, H); Janograptus Tullberg, 1880; Jenkinsograptus Gutiérrez-Marco, 1986; Parazygograptus Kozłowski, 1954; Trigonograpsus Nicholson, 1869.

Discussion. - Didymograptidae may turn out to be a monophyletic group of two-stiped graptoloids with a variably developed colony shape and little variation in the proximal 
end development, but a cladistic analysis of most taxa of the group does not exist. Maletz (1994, fig. 3) used the proximal development with symmetrical position of the crossing canals, the originally isograptid proximal development and the change in the position of the origin of th $1^{1}$ from Baltograptus to Didymograptus and Aulograptus to infer an evolutionary relationship of the didymograptids. These taxa with metasicular origin of th $1^{1}$ are preceeded by expansograptids with prosicular origin of th $1^{1}$, referable to the genus Cymatograptus (see range charts in Egenhoff \& Maletz, 2007).

$\mathrm{Mu}$ (1950) erected the rarely used family Didymograptidae for two-stiped dichograptids. The family originally included two subfamilies: Didymograptinae $\mathrm{Mu}, 1950$ and Pterograptinae $\mathrm{Mu}, 1950$. Ge (in $\mathrm{Mu}$ et al. 2002, p. 316) added the new subfamily Mimograptinae. The genus Mimograptus is here referred to the Dichograptidae, however, as it appears to possess dichotomous branchings distally.

Didymograptidae (Fig. 13A-H) represents a small family of two-stiped dichograptids with a fairly symmetrical disposition of the stipes, a large sicula with a relatively small prosicula and simple thecae along the stipes. They certainly originated from a multiramous ancestor, but details are not available. The earliest members appear in the lower Floian Tetragraptus approximatus Biozone, but may be preceded by the possibly related, also two-stiped "Kiaerograptus" supremus Lindholm (Fig. 10A). A number of taxa are known from relief material (Fig. 13) and even from isolated specimens (e.g. Holm 1895; Skwarko 1968, 1974; Maletz 1994a; Maletz \& Slovacek 2013).

Family Pterograptidae $\mathrm{Mu}, 1950$

(ex Pterograptinae Mu, 1950, p. 180)

Diagnosis (emended). - Two-stiped, pendent to deflexed and horizontal graptoloids; sicula conical, widening distinctly towards the aperture, with small prosicula or parallel-sided with comparably large and wide prosicula; sicula with distinct dorsal virgellar spine; thecae simple, widening tubes without or with moderate development of a rutellum; proximal development isograptid or artus-type; cladial branching in some taxa.

Genera included. - Didymograptellus Cooper \& Fortey, 1982 (Fig. 13I, J); Pseudobryograptus Mu, 1957; Pterograptus Holm, 1881b (Fig. 13K); Xiphograptus Cooper \& Fortey, 1982 (Fig. 13L); Yutagraptus Riva, 1994.

Discussion. - The characteristic dorsal virgellar spine can be seen as the defining synapomorphy and the family might be monophyletic. Maletz et al. (2009) indicated a tight group of virgellate taxa among the stem reclinatids, but the internal structure with the genus Acrograptus as the most derived taxon is unlikely to be correct. Acrograptus bears an asymmetrical proximal end with slender crossing canals, but lacks the dorsal virgellar spine of all other members (Xiphograptus to Didymograptellus: Maletz et al. 2009, fig. 2). The genus is herein referred to the Sigmagraptidae.

Pterograptidae (Fig. 13I-L) is used here to incorporate the virgellate dichograptids, except for the four-stiped, scandent members of the genus Phyllograptus (see family Tetragraptidae) in which the virgellar spine evolved independently (Maletz 2010). The proximal end is quite variable with the dimensions of the prosicula changing considerably from the early taxa with a comparably large prosicula (Didymograptellus: Fig. 13I, J) to a small one in later taxa (Xiphograptus: Fig. 13L). The proximal development originally was of isograptid type, but derived species may show an artus-type development (Fig. 13K). The thecae are simple with straight apertures, lacking a distinct rutellum, variably inclined and with constant thecal overlap. All taxa show a two-stiped rhabdosome with a variable orientation of the stipes from pendent to deflexed and horizontal, sometimes also slightly reflexed. The development of a multiramous, pendent colony shape in Pterograptus (Maletz 1994b) and Pseudobryograptus is based on the formation of thecal cladia at each theca, but on alternating sides of the stipe.

The origin of Pterograptidae can be seen in the Floian (Maletz 2010, fig. 7) with the genus Didymograptellus, bearing primitive, symplesiomorphic characters like the high prosicular origin of th $1^{1}$, and simple thecae. Characters derived early in the evolution of the group are the large prosicula with a parallel-sided metasicula, adorned with a dorsal virgellar spine (Maletz 2010). A large parallel-sided prosicula and metasicula may, however, be present in the genera Kiaerograptus, Ancoragraptus and Psigraptus (see Spjeldnaes 1963, pl. 18), but in these taxa the metasicula is freely hanging below the stipes. The origin of the dorsal virgellar spine is unknown as no intermediate taxa are available showing its formation.

Based on the rhabdosome shape alone, it might be considered that the Pterograptidae originated from the Didymograptidae, but an independent origin from an anisograptid ancestor is more likely. This is supported by the high prosicular origin of th $1^{1}$, found so far only in the Anisograptidae (see Hutt 1974), but it is present also in some early members of the sigmagraptine genus Paradelograptus (see Fig. 10B).

Family Tetragraptidae Frech, 1897 (p. 593)

(ex subfamily Tetragraptini Frech, 1897, p. 593;

family Tetragraptidae Mu, 1950, p. 180)

(= order Tetragrapta in Maletz et al. 2009) (Fig. 14A, B, D)

Definition. - (Modified from Maletz et al. 2009, p. 12) The crown-clade Tetragraptidae is the common ancestor of 

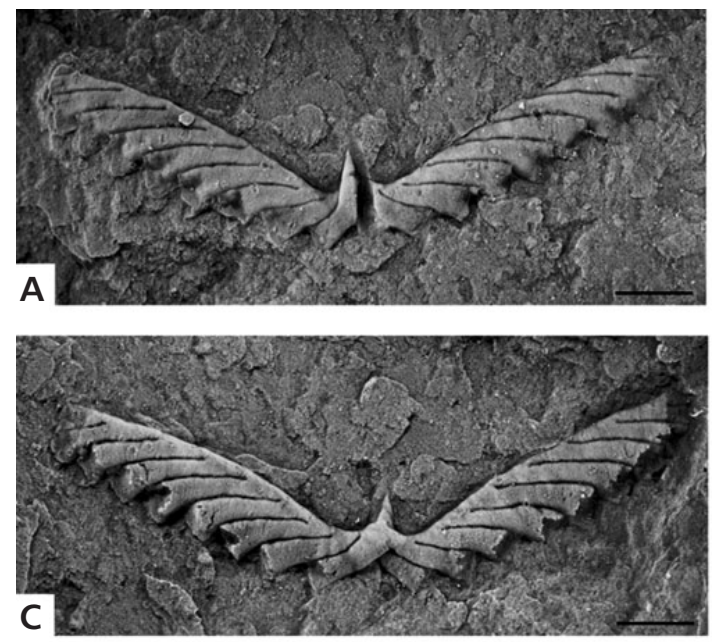
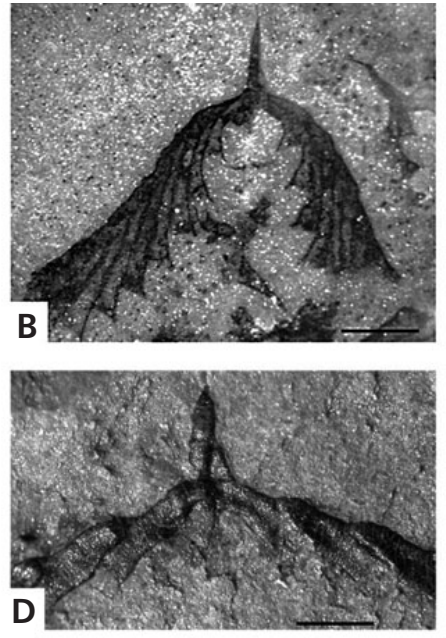
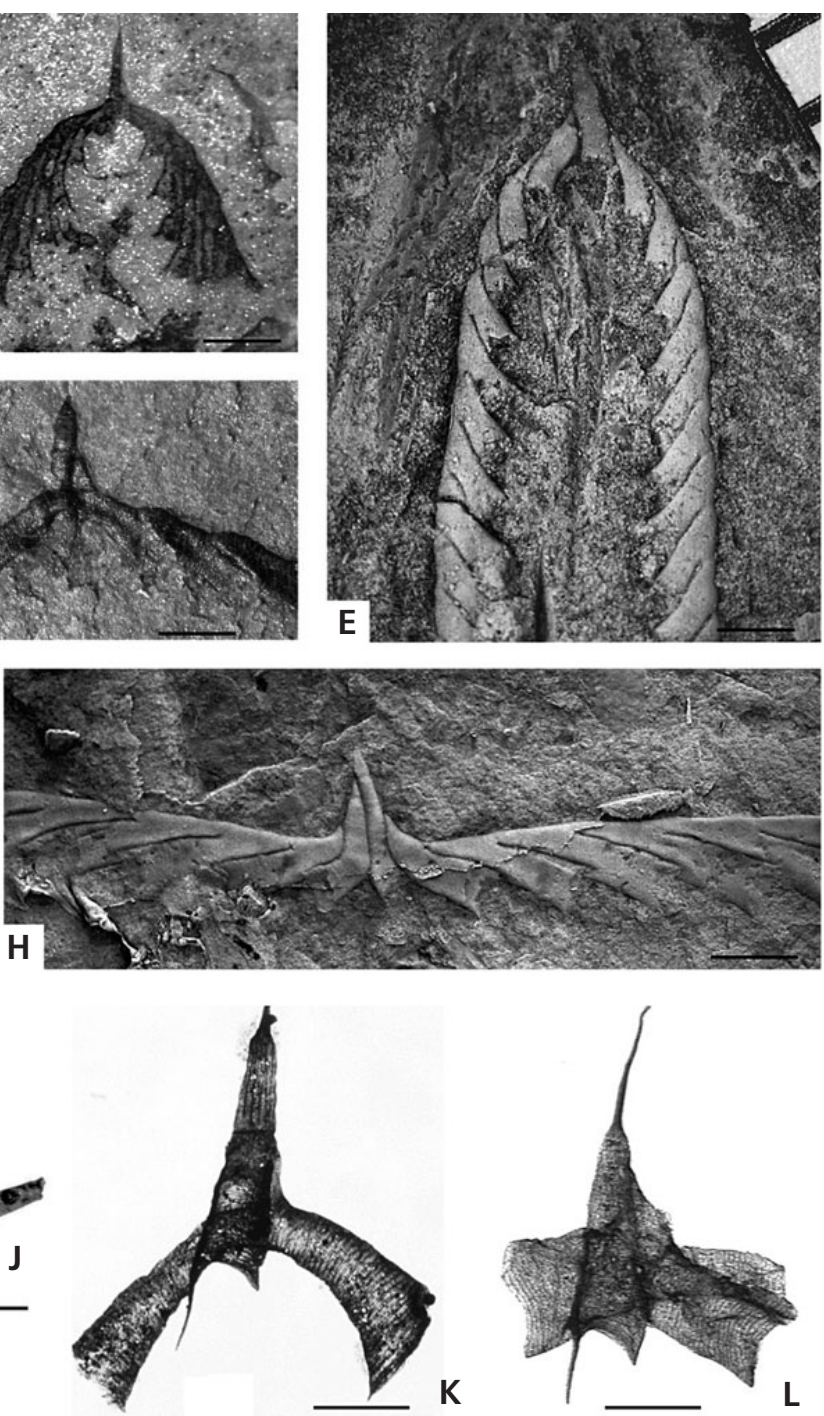

Figure 13. Didymograptidae and Pterograptidae. - A, C - Expansograptus latus (Hall) in obverse (A) and reverse (C) views, Di 739, latex. - B - Baltograptus kunmingensis (Ni in Mu et al.), CEGH-UNC 17564. • D - Cymatograptus bidextro Toro \& Maletz, IANIGLA-PI 1813, reverse view. - E - Didymograptus artus Elles \& Wood, LO 3266t, obverse view. • F - Baltograptus vacillans (Tullberg), Di 839/205, reverse view, latex. - G - Expansograptus sp., Di 2, latex, obverse view, showing small prosicula. - H - Expansograptus grandis (Monsen), obverse view. - I - Didymograptellus cowheadensis Maletz, GSC 133398, reverse view. • J - Didymograptellus bifidus (Hall), GSC 133419, juvenile sicula with large, parallel-sided prosicula. $• \mathrm{~K}$ - Pterograptus elegans Holm, GSC 102784, proximal end. • L - Xiphograptus lofuensis (Lee), GSC 133389. Latex (A, C, F-H), Infrared photos (I-L). Scale bar represents $1 \mathrm{~mm}(\mathrm{~A}-\mathrm{H})$ and $0.5 \mathrm{~mm}(\mathrm{I}-\mathrm{L})$.

Tetragraptus serra Brongniart and the first species to have distal dicalycal thecae limited to th $3^{1}$ and th $3^{2}$, forming a quadriramous rhabdosome.

Genera included. - Corymbograptus Obut \& Sobolevskaya, 1964; Paratetragraptus Obut, 1957; Pendeograptus Bouček \& Přibyl, 1951; Phyllograptus Hall, 1858; Pseudophyllograptus Cooper \& Fortey, 1982; Pseudotrigonograptus $\mathrm{Mu}$ \& Lee, 1958; Tetragrapsus Salter, 1863 (Figs 12B, 14A, B, D); Tristichograptus Jackson \& Bulman, 1970.

Discussion. - Maletz et al. (2009) defined the crown clade
Reclinata as the common ancestor of Tetragraptus serra and Exigraptus uniformis $\mathrm{Mu}$ in $\mathrm{Mu}$ et al. and all its descendents, including two monophyletic taxa, the Pan-Tetragrapta (Tetragraptidae herein) and the Pan-Bireclinata (all derived Graptoloidea). Apart from a definition, the authors provided information on a number of synapomorphies for the Reclinata (Fig. 2). These are the presence of a rutellum on the sicula and on the thecae and an elongated or enlarged sicula. Reclinata may be a definable taxon, but appears to be unnecessary, as it adds an unwarranted hierarchical level to the taxonomy. The origin of the subcohort Reclinata from the cohort Pan-Reclinata is unresolved. Maletz 

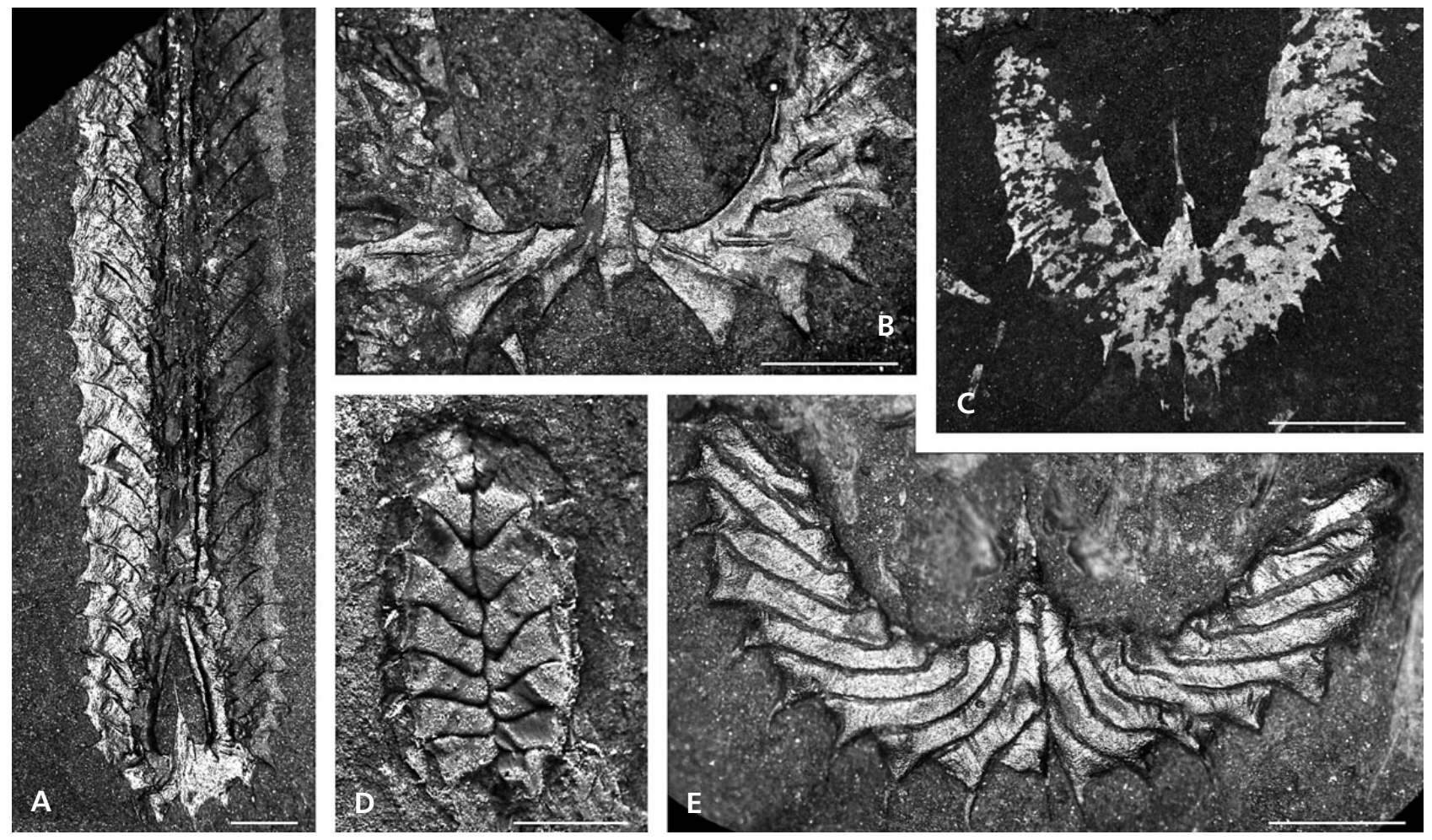

Figure 14. Tetragraptidae and Isograptidae. • A, D - Tetragraptus cor (Strandmark) in 1-2 (A) and a-b (D) preservation, Lerhamn drillcore at 19.55 m latex (D). • B - Tetragraptus reclinatus Elles \& Wood in 1-2 preservation in obverse view, LO 10598t, Lerhamn drillcore. • C - Isograptus mobergi Maletz, flattened, SGU $3179 \mathrm{gr04b} \cdot$ E-Arienigraptus geniculatus (Skevington), LO 10601t, relief specimen in reverse view showing manubrium. Scale bar represents $1 \mathrm{~mm}$.

et al. (2009, fig. 2) showed a sister-group relationship to Aulograptus, which is highly unlikely as this taxon is a quite derived didymograptid with an isograptid proximal development, low metasicular origin of th $1^{1}$ and complex, geniculate thecae. Reclinata, however, includes four-stiped taxa with a prosicular origin of th $1^{1}$ on the sicula and their descendents, most probably derived from a multiramous dichograptid ancestor.

Tetragraptidae can be characterised by a four- to two-stiped, pendent to horizontal, reclined, reflexed and scandent, biradiate rhabdosome. The sicula is conical, widening distinctly towards the aperture, with a relatively small prosicula. The thecae are simple, widening tubes often with distinct rutellum. Tetragraptidae is defined as a monophyletic taxon (Maletz et al. 2009, fig. 2), which contradicts the notion of Maletz \& Mitchell (1996) that the isograptids originate from a reclined tetragraptid ancestor.

Tetragraptidae was erected as a family by $\mathrm{Mu}(1950)$ as a form taxon including four-stiped dichograptids, but Frech (1897) had already used the term Tetragraptini for a subfamily of the Dichograptidae and the term Tetragraptidae is, therefore, attributed to him. The phylogenetic relationships of some of the original members exclude them from the taxon, but a clearly defined group of gener- ally four-stiped dichograptids can be referred to the Tetragraptidae (see Maletz et al. 2009: superorder Pan-Tetragrapta). There is little doubt, that the scandent tetragraptids (phyllograptids) can be included in Tetragraptidae as derived members (Maletz et al. 2009), as they are connected through a number of intermediate taxa [e.g. Tetragraptus cor Strandmark, often identified as Pseudophyllograptus cor (Fig. 14A, D), Tetragraptus phyllograptoides: Cooper \& Lindholm 1985].

Maletz et al. (2009) included Perissograptus pygmaeus Ruedemann as a derived member of Tetragraptidae. The proximal development with the long free hanging apertural part of the sicula and the thecal style, however, suggest a relationship to the sigmagraptines and especially the genus Maeandrograptus.

\section{Suborder Glossograptina Jaanusson, 1960 (p. 319)}

Definition. - The paraphyletic taxon Glossograptina includes the partial clade identified by the isograptid symmetry of the colony as the defining synapomorphy (see Maletz \& Mitchell 1996, fig. 8; Maletz et al. 2009, fig. 2: PanBireclinata), but excludes the Axonophora (biserial, dipleural graptoloids). 


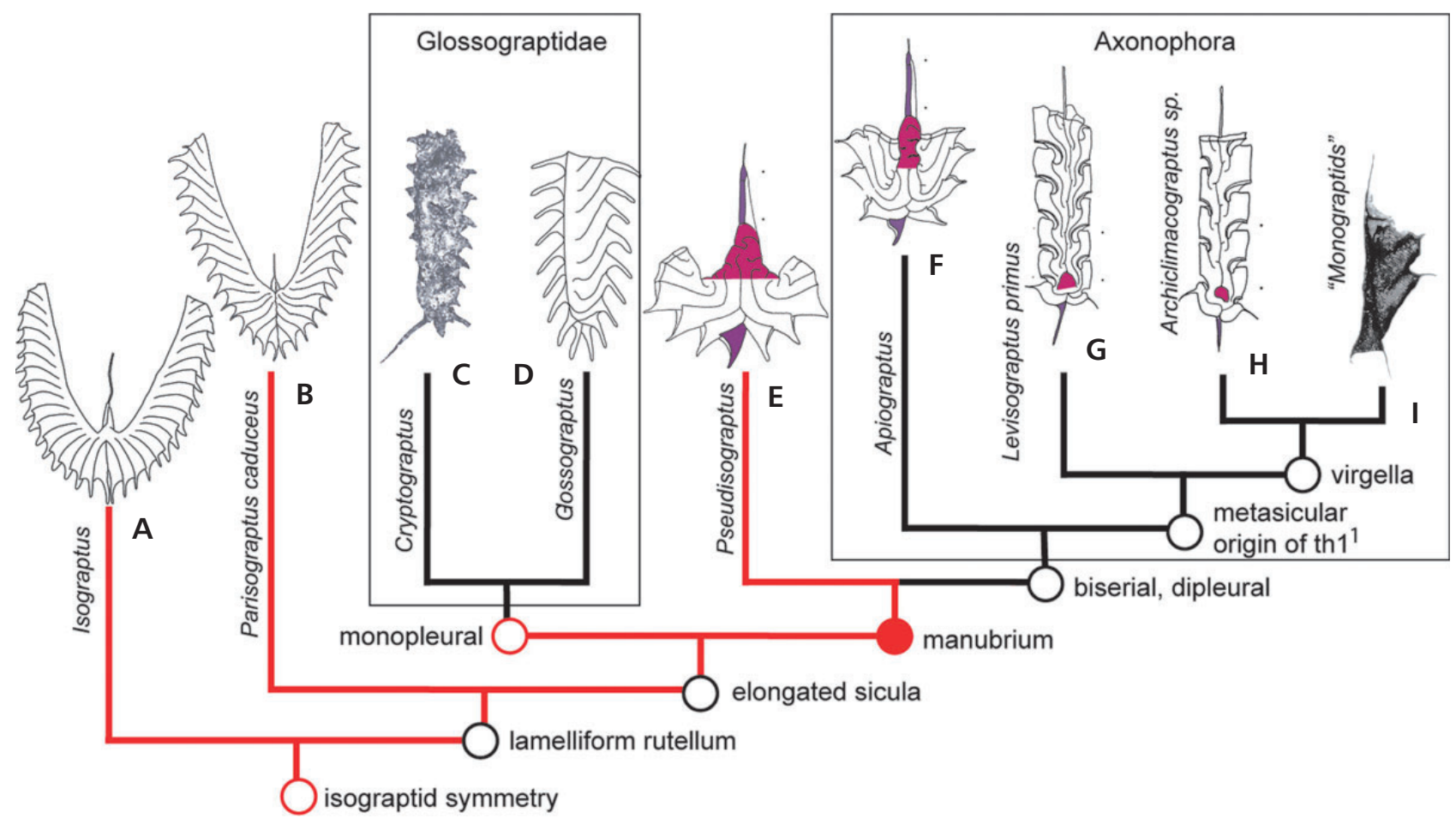

Figure 15. The Isograptidae and the expression of the manubrium in their descendants, based on data in Maletz (2010, fig. 4). A number of photos of axonophorans have been changed to line drawings to show the remains of the manubrium more clearly. This diagram is not compatible with the interpretation of Maletz \& Mitchell (1996, fig. 8) and both show only part of the complex history of the groups. Manubrium and remains of it shown in red (E-H). Red lines in diagram indicate taxa belonging to the Isograptidae.

Discussion. - Glossograptina are two-stiped, reclined to scandent, biradiate graptoloids with isograptid symmetry. Scandent taxa have a monopleural or dipleural arrangement of the stipes. The sicula is conical, widening distinctly towards the aperture and possesses a small prosicula. The proximal development is isograptid, dextral with prosicular origin of th $1^{1}$ or derived pattern. The thecae are simple, slowly widening tubes, often with distinct rutellum. Lateral apertural thecal spines and a lacinia are present in derived taxa and attenuation of the fusellum (periderm in earlier papers) is common.

Glossograptina (Fig. 2) includes the suborder PanGlossograpta and the "stem-isograptids" of the Pan-Bireclinata of Maletz et al. (2009). The taxon Pan-Bireclinata is not used herein as it would add another unnecessary level in the taxonomic hierarchy. Pan-Bireclinata is a cladistically defined monophyletic taxon, including all twostiped taxa with an isograptid symmetry and their descendants, starting with the genus Isograptus Moberg. The order Bireclinata of Maletz et al. (2009) includes all Glossograptidae as discussed herein and the derived PanAxonophora (biserial graptolites and derived taxa). The only detailed cladistic analysis of the Isograptidae and Glossograptidae by Maletz \& Mitchell (1996, fig. 8) indicates that the Glossograptidae (monopleural taxa) and the Axonophora (dipleural taxa) originate independently from different isograptid ancestors. The result in Maletz et al. (2009), thus, may have to be explained as an artefact of low resolution of the analysis as only a single species of the genus Isograptus was included.

Maletz \& Mitchell (1996, p. 651) included the isograptids in an expanded family Glossograptidae to show their close phylogenetic relationships. The authors (Maletz \& Mitchell 1996, p. 651) stated that it is not possible to define a taxon as a monophyletic unit without including both, the traditional glossograptids and the isograptids. Glossograptina, including the stem group, is defined by the reclined two-stiped rhabdosome with an isograptid symmetry (defining synapomorphy) as a paraphyletic group, excluding Axonophora as biserial, dipleural graptoloids.

Family Isograptidae Harris, 1933 (p. 85)

(incl. family Arienigraptidae Yu \& Fang, 1981, p. 29;

emend. Maletz \& Mitchell, 1996, p. 653;

ex Arienigraptinae Yu \& Fang, 1981

[= Pseudisograptidae Cooper \& Ni, 1986])

Definition. - The family Isograptidae is the paraphyletic partial clade based on the reclined, two-stiped colony with the isograptid symmetry as the defining synapomorphy (see 
Maletz \& Mitchell 1996), but excluding the monophyletic Glossograptidae with a monopleural colony shape and the virgellate Axonophora with the biserial, dipleural development of the colonies.

Genera included. - Arienigraptus Yu \& Fang, 1981 (Fig. 14E); Cardiograptus Harris \& Keble, 1916 in Harris (1916); Isograptus Moberg, 1892 (Fig. 14C); Oncograptus Hall, 1914; Paracardiograptus Mu \& Lee, 1958; Parisograptus Chen \& Zhang, 1996 (Fig. 15B); Procardiograptus Xiao, Xia \& Wang 1985; Proncograptus Xiao, Xia \& Wang, 1985; Pseudisograptus Beavis, 1972 (Fig. 15E); Xiushuigraptus Yu \& Fang, 1983.

Discussion. - Isograptidae is a paraphyletic taxon from which two clades of scandent, biserial graptolites originated independently, the small clade of the family Glossograptidae and the axonophorans, as was shown by Maletz \& Mitchell (1996, fig. 8). Isograptidae was not discussed by Maletz et al. (2009, fig. 2), who identified the genera Isograptus and Parisograptus as "stem isograptids", but did not define this group.

Isograptidae includes two-stiped, reclined to scandent, biradiate graptoloids with isograptid or derived maeandrograptid symmetry, with or without manubrium. The scandent taxa of the family (Cardiograptus, Procardiograptus) are dipleural. The sicula is conical, often elongated and widens slowly towards the aperture. The prosicula is relatively small, less than one-fourth of the length of the metasicula. The origin of th $1^{1}$ is in the lower part of the prosicula. The proximal development is isograptid, dextral. The thecae are simple, widening tubes, often with distinct rutellum.

Isograptidae includes the group of manubriate isograptids (e.g. Cooper 1973). The origin of the Isograptidae lies within the reclined tetragraptids of the genus Tetragraptus (Maletz \& Mitchell 1996, Maletz et al. 2009, Maletz 2010). The Isograptidae led to the scandent monopleural Glossograptidae through a taxon similar to the partial monopleural Bergstroemograptus (Maletz \& Mitchell 1996), but the differentiation of the two groups is difficult as the synapomorphies are hard to identify from flattened material. A second independent lineage led from the derived arienigraptids to the axonophoran graptolites (Fig. 15). Isograptids provide a number of quite important biostratigraphical marker species for the Dapingian to Darriwilian (Middle Ordovician) (Harris 1933, Cooper 1973).

Yu \& Fang (1981) originally defined Arienigraptinae as a subfamily of Kalpinograptidae Jiao, 1977 (Qiao in Mu et al. 2002, p. 369). Maletz \& Mitchell (1996) elevated the subfamily to family rank and recognized the genus Arienigraptus (Fig. 14E) as a pseudisograptid, while Kalpinograptus Jiao is now regarded as a secondarily two-stiped glossograptid (Maletz \& Mitchell 1996). The arienigraptids are here included in Isograptidae as was done by Harris (1933) and are interpreted as a paraphyletic group, from which the Axonophora, the biserial, dipleural graptolites originated (Mitchell et al. 1995, Fortey et al. 2005, Maletz 2010). The definition of the precise boundary between Isograptidae and Axonophora remains problematical and is difficult to establish because of the need for well-preserved and isolated specimens to observe the important synapomorphic characters in this transition (see discussion under Axonophora).

Family Glossograptidae Lapworth, 1873b (p. 555) (incl. Kalpinograptidae Jiao, 1977)

Definition. - (Maletz et al. 2009, p. 14) The crown clade Glossograptidae is the common ancestor of Glossograptus acanthus Elles \& Wood and the first species to have a monopleural arrangement of the stipes.

Genera included. - Apoglossograptus Finney, 1978; Bergstroemograptus Finney \& Chen, 1984; Corynites Kozłowski, 1956; Corynograptus Hopkinson \& Lapworth, 1875; Corynoides Nicholson, 1867; Cryptograptus Lapworth, 1880f (Fig. 15C); Glossograpsus Emmons, 1855 (Fig. 15D); Kalpinograptus Jiao, 1977; Lonchograptus Tullberg, 1880; Mimograptus Lapworth, 1908 in Elles \& Wood (1908) (non Mimograptus Harris \& Thomas, 1940: see Dichograptidae); Nanograptus Hadding, 1915; Paraglossograptus Mu in Hsü, 1959; Rogercooperia Sherwin \& Rickards, 2000; Sinoretiograptus Mu et al., 1974; Skiagraptus Harris, 1933; Tonograptus Williams, 1992.

Discussion. - Glossograptidae includes two-stiped, scandent, biradiate graptoloids with isograptid symmetry and monopleural development. The sicula is conical, widening distinctly towards the aperture and possesses a relatively small prosicula. The thecae are simple, widening tubes with distinct rutellum. Apertural thecal spines are common and are connected by a lacinia in a few taxa. A number of taxa show a reduction of the fusellum or a reduction of the number of thecae.

The monophyletic Glossograptidae is a group of biserial, monopleural taxa (Fig. 15D) with a simple isograptid proximal development covered by the later growth of the colony. Thus, proximal end development is hard to verify and has been a matter of debate for many years (Bulman 1945, Strachan 1985, Maletz \& Mitchell 1996). Some of the younger members are included even though their colony development is so reduced that important characteristics for an analysis are not recognizable (e.g. Corynoides, Corynites). 


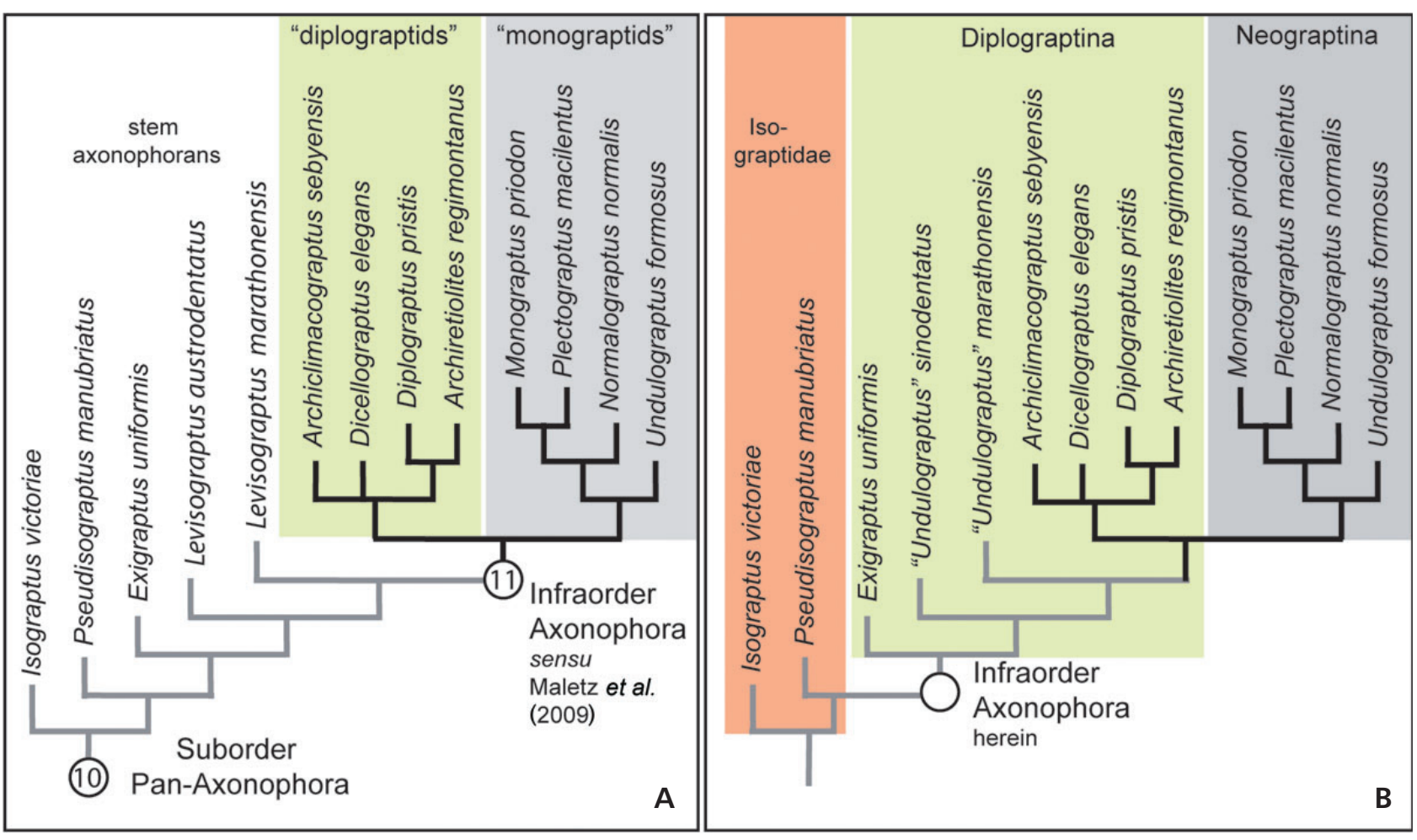

Figure 16. The Axonophora. • A - modified from Maletz et al. (2009, fig. 6). • B - revised interpretation showing concept of the Axonophora used herein. Undulograptus formosus may be in wrong position in $\mathrm{B}$; see discussion in text.

Suborder Axonophora Frech, 1897 (p. 607)

[= Virgellina Fortey \& Cooper, 1986, p. 639;

Fortey et al. 2005, p. 1255

(pars; see Maletz 2010 for the exclusion of xiphograptids and phyllograptids); = Diplograptacea in Mitchell, 1987;

= Diplograptoidea in Mitchell et al. 2007]

Definition. - (Revised from Maletz et al. 2009, p. 14) The crown clade Axonophora is the first species to acquire a biserial, dipleural rhabdosome and all its descendants.

Discussion. - Axonophora can be described as graptoloids with a nema as the leading rod followed by or engulfed in the growth of the thecal rows. The rhabdosomes are either biserial or uniserial. The proximal development is complex, with prosicular or more commonly metasicular origin of th $1^{1}$ and delayed dicalycal theca.

Maletz et al. (2009) defined the total clade Pan-Axonophora by two synapomorphies: presence of a manubrium and the left-handed origin of th $1^{2}$ from the obverse side of th $1^{1}$ (Maletz et al. 2009, p. 14). However, the left-handed origin of th $1^{2}$ from th $1^{1}$ would exclude the genus Arienigraptus from Pan-Axonophora and, thus, disrupt a small and precisely defined group, the arienigraptids or pseudisograptids sensu Maletz \& Mitchell (1996). The taxon is, therefore not used and it is suggested to examine more details of early axonophoran evolution, of which lit- tle is known so far (see Maletz 2011c) and phylogenetic interpretations are controversial.

Maletz \& Mitchell (1996, fig. 8) indicated the origin of Arienigraptidae [Isograptidae herein], and with it Axonophora, from an early isograptid ancestor, prior to the separation of the Parisograptus lineage leading to Glossograptina. Thus, Glossograptidae and the Axonophora originate separately from an isograptid ancestor (Fig. 15). In the less well resolved analysis of Maletz et al. (2009), the order Bireclinata (Pan-Glossograpta and Pan-Axonophora) is shown to originate as a sister group to the genus Parisograptus.

Axonophora as used here is a monophyletic clade. The name should be used in the sense of Frech (1897), including all dipleural biserials with a nema included in the biserial rhabdosome and the monograptids with the nema leading the growth of the stipe (Fig. 16B). Frech (1897), however, largely misinterpreted the colony development, following Ruedemann's (1895) reconstructions of synrhabdosomes in his understanding, but recognized the importance of the nema for the growth of the colonies and for the evolutionary relationships it indicates. As he did not know details of the proximal development of graptolites, he did not consider the characters that are so important for our modern interpretation of graptolites. Fortey et al. (2005, p. 1255) discussed the early evolution of the axonophorans, but preferred the name Virgellina 
for this clade, called the Diplograptoidea by Mitchell et al. (2007).

Maletz et al. (2009) used a slightly different concept, excluding the early biserials of the "Undulograptus" (now: Levisograptus) austrodentatus group (see Maletz 2011a) with the aim of creating an infraorder Axonophora with two monophyletic sister groups (Fig. 17A). The authors separated the Levisograptus austrodentatus group as stem axonophorans and added Arienigraptidae sensu Maletz \& Mitchell (1996) to the stem. Their definition modifies the Axonophora in a way that excludes the austrodentatus group, which have generally been accepted as earliest biserials or axonophorans in the past. It is here advocated to include all biserial, dipleural taxa derived from the two-stiped genus Pseudisograptus, thus including even the early biserial, dipleural genera Exigraptus $\mathrm{Mu}$ in $\mathrm{Mu}$ et al. and Apiograptus Cooper \& McLaurin as axonophorans.

A major problem in the understanding of the axonophorans is the lack of knowledge of proximal development types (Fig. 18) and rhabdosome construction of the early transitional taxa. The general transition of Isograptidae to Axonophora has been established (see Mitchell et al. 1995, Fortey et al. 2005, Maletz 2010), but important details are not available. Maletz (2010, fig. 4) discussed the evolutionary origin and modification of the ventral virgellar spine of the Axonophora, but did not provide information on other details of the proximal development. A change from a prosicular origin of th $1^{1}$ (Isograptidae) to the metasicular origin (Axonophora) is known, but it is uncertain how and when the transition took place. The earliest known taxon with a metasicular origin of th $1^{1}$ is Levisograptus sinodentatus Mu \& Lee (see Mitchell 1994, fig. 1C). The biserial, dipleural Exigraptus uniformis $\mathrm{Mu}$ in $\mathrm{Mu}$ et al. still shows a high, possibly prosicular origin of th $1^{1}$ (Mitchell \& Maletz 1995) as is found in typical pseudisograptids (see Cooper \& Ni 1986), but bears a pattern $\mathrm{U}$ astogeny (Fortey et al. 2005).

As any solution would mean an artificial break within a lineage, I would prefer to make one that can be followed easily even in poorly preserved material. Thus, I would advocate identifying the genera Exigraptus and Apiograptus with a manubrium and a prosicular origin of th $1^{1}$, indicating a close relationship to the Isograptidae, as the earliest (known) axonophorans. The defining synapomorphy then will be the biserial, dipleural rhabdosome (Fig. 16B) following the concept of Frech (1897). The manubrium or remains of it in the early axonophorans Exigraptus, Apiograptus and Levisograptus Maletz (Fig. 15) represents a symplesiomorphic character shared with the Isograptidae. The lamelliform rutellum evolved into a virgella during the evolution of the early axonophorans, but is not characteristic of the earliest taxa as the genus Levisograptus retains a lanceolate virgella (Maletz 2010). The development of the virgella in Exigraptus and Apiograptus remains unknown.
Infraorder Diplograptina Lapworth, 1880e (p. 19)

[ex Diplograpta Lapworth, 1880e, p. 191;

transl. Obut, 1957, p. 17]

(= suborder Diplograptacea Lapworth in Mitchell, 1987, p. 367 ;

$=$ order Diplograptoidea in Mitchell et al. 2007; non superfamily Diplograptoidea in Štorch et al. 2011, fig. 6)

Diagnosis (emended). - Biserial, dipleural axonophorans, secondarily two-stiped or partly two-stiped or with cladial branching; proximal end with or without a manubrium, initially with prosicular origin of th $1^{1}$, but metasicular origin of th $1^{1}$ in derived taxa; proximal end square to highly asymmetrical, generally provided with a virgellar spine and additional apertural spines on the first thecal pair at least; proximal development type progressively more simple, losing the manubrium; thecae variable, often with complex apertural or genicular additions; intrathecal folds and complete median septum in earlier taxa; rhabdosome with attenuated fusellum in some taxa.

Discussion. - Diplograptina as used herein is not identical to the Diplograptina of Storch et al. (2011, p. 315), as it includes also the stem group taxa starting with the first biserial, dipleural taxon. Diplograptina as used herein is a paraphyletic unit from which Neograptina originated. Maletz et al. (2009, fig. 6) decided to exclude the early axonophorans as stem group axonophorans in order to create two monophyletic clades, Diplograptina ("diplograptids") and Neograptina ("monograptids"), an argument that is not followed here. Storch et al. (2011) also differentiated two major clades in the Axonophora (Fig. 17). The detailed relationships of both taxa are still uncertain, as the early evolution of the axonophorans is poorly known (Maletz 2011c). Storch et al. (2011, p. 368) recognized the earliest taxon of the Neograptina as Undulograptus formosus $\mathrm{Mu} \&$ Lee, a typical axonophoran with a pattern $\mathrm{C}$ astogeny (Mitchell et al. 2007, fig. 1), most probably derived from a diplograptine ancestor as is indicated by its derived proximal development pattern (see Fig. 18). This leads to the interpretation of the Diplograptina as a paraphyletic taxon from which the Neograptina originated in the early Darriwilian (see also Fig. 16). The concept used here for the Diplograptina differs from that of Mitchell et al. (2007, fig. 1A) mainly through the inclusion of the stem group of earliest biserials and is identical to their order Diplograptoidea.

Storch et al. (2011) included the superfamilies Dicranograptoidea, Diplograptoidea and Climacograptoidea in the Diplograptina (Fig. 17A) and showed the origin of these in a unresolved trichotomy. It is here suggested to keep these units as family level taxa (Fig. 17B) and regard the superfamilies as an unnecessary rank within the Diplograptina.

The proximal development types of the Diplograptina (e.g. Mitchell 1987, Melchin 1998, Melchin et al. 2011) 

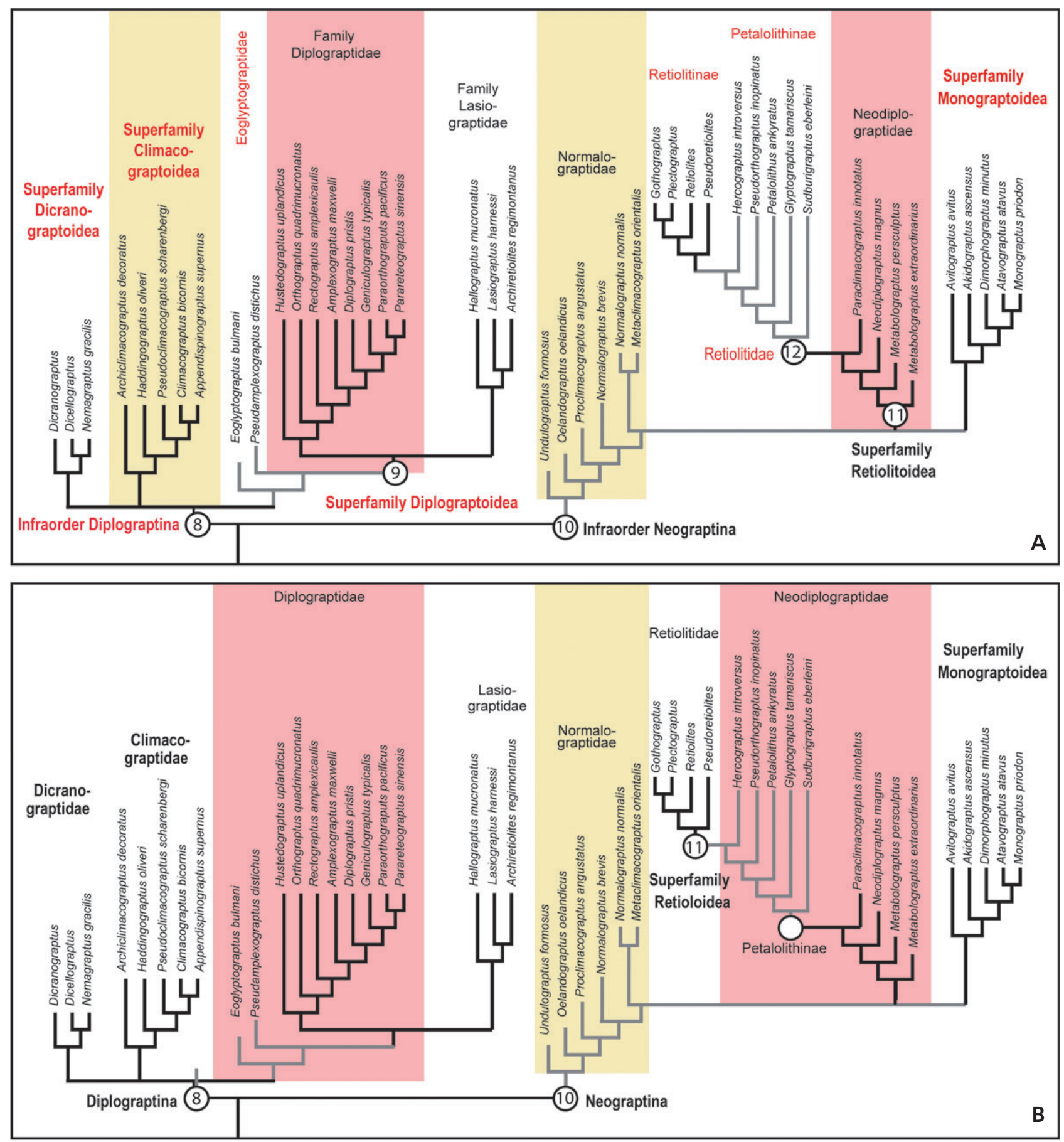

Figure 17. A - the differentiation of the Axonophora (diagram based on Mitchell et al. 2007, Melchin et al. 2011, Štorch et al. 2011 as compiled by Mitchell \& Melchin 2011). Taxa not used or used in a different context indicated in red. $\bullet$ B - the alternative interpretation preferred here. The diagram does not show the earliest Axonophora (Exigraptus, Apiograptus, Levisograptus: see text). Undulograptus, Oelandograptus and Proclimacograptus should be removed from the Neograptina and transferred to the Climacograptidae.

have been proven useful for an understanding of the taxonomy and evolution of biserial graptolites. They show the complex origins and growth directions of the proximal thecae of the biserial colonies (Fig. 18), but are difficult to understand without isolated growth series of the taxa. The earliest known development is the pattern $U$ astogeny of Levisograptus (Fig. 18U), derived from the manubriate genera Pseudisograptus and Apiograptus (see Fig. 15). Simplification led to the derived patterns and eventually through the loss of the dicalycal theca and the second stipe 

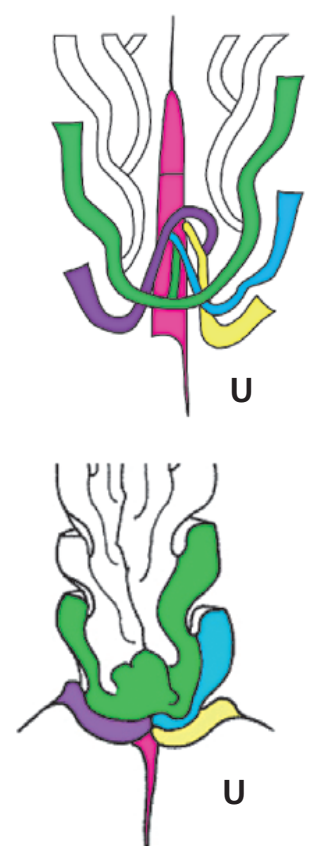
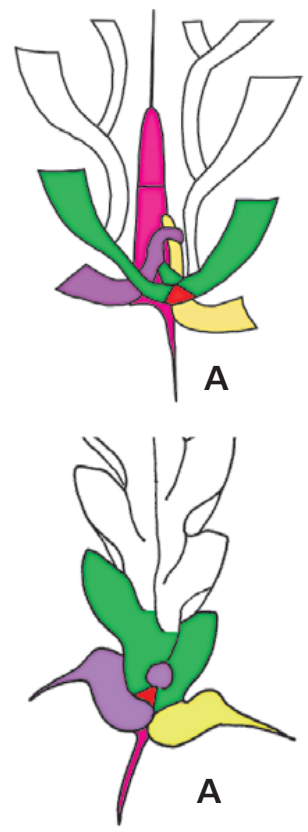
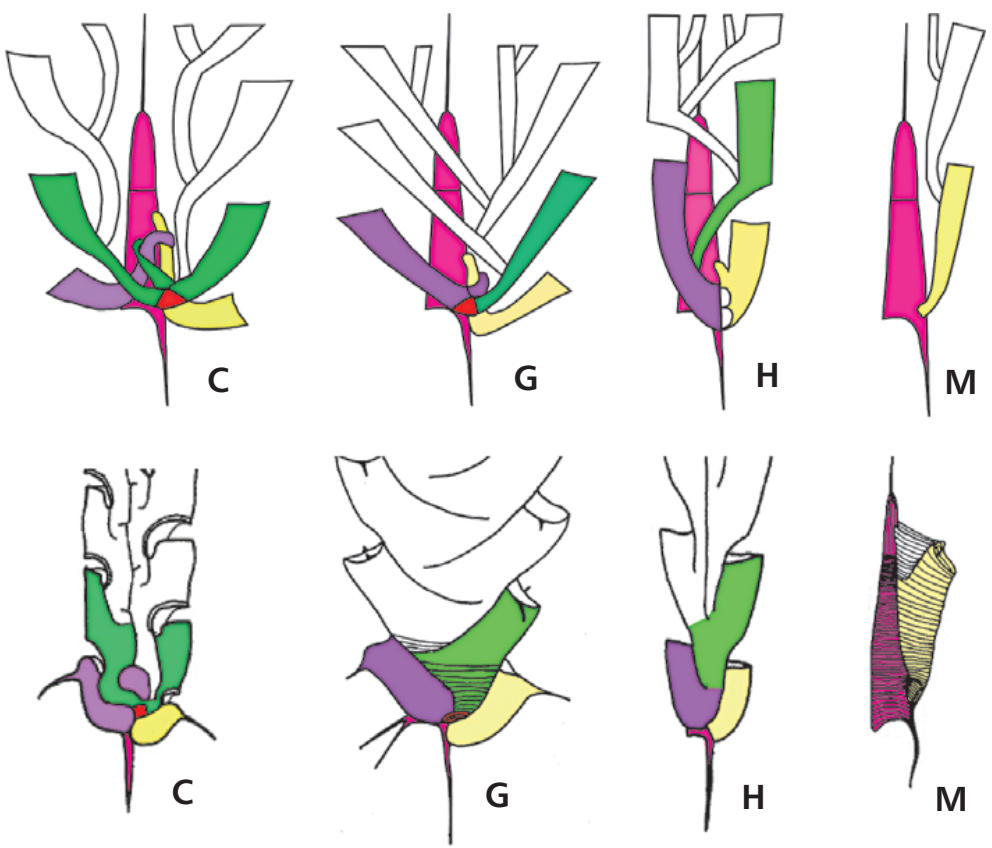

Figure 18. Important proximal development types in the Axonophora. The upper row shows the development types discussed in the text. The lower row shows corresponding illustrations of proximal ends of representative specimens in reverse view. • Pattern U astogeny, Levisograptus austrodentatus Harris \& Keble. • Pattern A astogeny, Hustedograptus teretisuculus (Hisinger). • Pattern C astogeny, Archiclimacograptus angulatus (Bulman). • Pattern G astogeny, Orthograptus quadrimucronatus (Hall). • Pattern H astogeny, Normalograptus antiquus (Ge). Pattern M astogeny, Pristiograptus dubius (Suess).

to the pattern $\mathrm{M}$ astogeny (Fig. 18M) of the Monograptidae. The evolutionary transitions between most of these development patterns are poorly known, however.

Family Diplograptidae Lapworth, 1873b

(table 1 facing p. 555)

(incl. Orthograptidae Mitchell, 1987, p. 377;

Peiragraptidae Jaanusson, 1960)

Diagnosis (emended). - Biserial, dipleural axonophorans; proximal end with or without a manubrium, initially with prosicular origin of th $1^{1}$, but metasicular origin of th $1^{1}$ in derived taxa; proximal end square to highly asymmetrical, generally provided with a virgellar spine and additional apertural spines on the first thecal pair; proximal development type progressively more simple, losing the manubrium; thecae variable, often with complex apertural or genicular additions; intrathecal folds and complete median septum in earlier taxa; rhabdosome with attenuated fusellum in some derived taxa.

Subfamily Diplograptinae Lapworth, 1873b (table 1 facing p. 555)

Diagnosis. - Biserial, dipleural axonophorans; proximal end with or without a manubrium, initially with prosicular origin of th $1^{1}$, but metasicular origin of th $1^{1}$ in derived taxa; proximal end square to highly asymmetrical, gene- rally provided with a virgellar spine and additional apertural spines on the first thecal pair; proximal development type progressively more simple, losing the manubrium; thecae variable, often with complex apertural or genicular additions; intrathecal folds and complete median septum in earlier taxa; rhabdosome with attenuated fusellum in some derived taxa; excluding aseptate to septate taxa with paired antivirgellar spines and a pattern A or G astogeny (Orthograptinae, Lasiograptidae).

Genera included. - Apiograptus Cooper \& McLaurin, 1974; Archiclimacograptus Mitchell, 1987 (Figs 18C, 19F, G); Diplograpsis M'Coy, 1850 (Fig. 19N); Eoglyptograptus Mitchell, 1987 (Fig. 19H); Exigraptus Mu, 1979 in Mu et al. (1979); Fenhshiangograptus Hong, 1957; Levisograptus Maletz 2011 (Figs 18U, 19C-E); Mesograptus Elles \& Wood, 1907; Oepikograptus Obut, 1987 (Fig. 19K); Prorectograptus Li, 1994; Pseudamplexograptus Mitchell, 1987 (Fig. 19I, J); Urbanekograptus Mitchell, 1987.

Discussion. - Diplograptinae as used herein is a paraphyletic taxon from which Lasiograptidae originated as a monophyletic clade (Fig. 17B). The early biserials Apiograptus and Exigraptus (Fig. 19A, B) are here included in Diplograptidae, even though they are not shown in the cladistic analysis (Fig. 17). Thus, Diplograptidae include the earliest axonophorans. The precise differentiation of Climacograptidae (discussion in Maletz 2011b) and Dicranograptidae (see Maletz 1998) is unclear and more work on early 

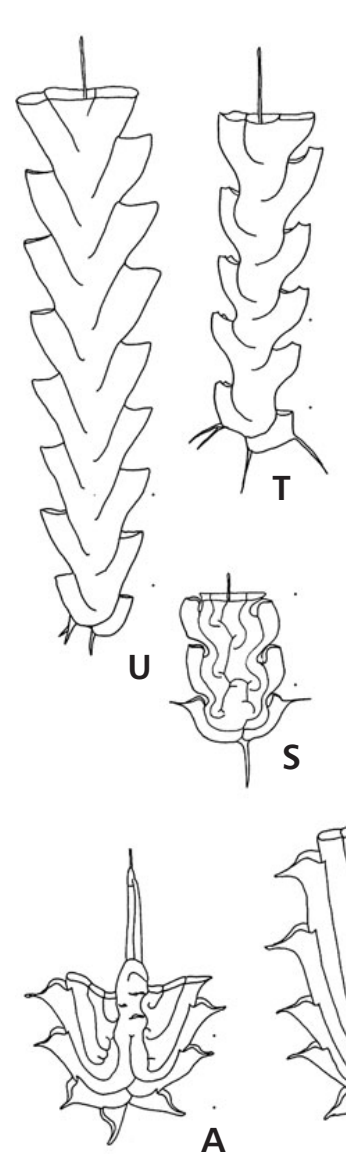
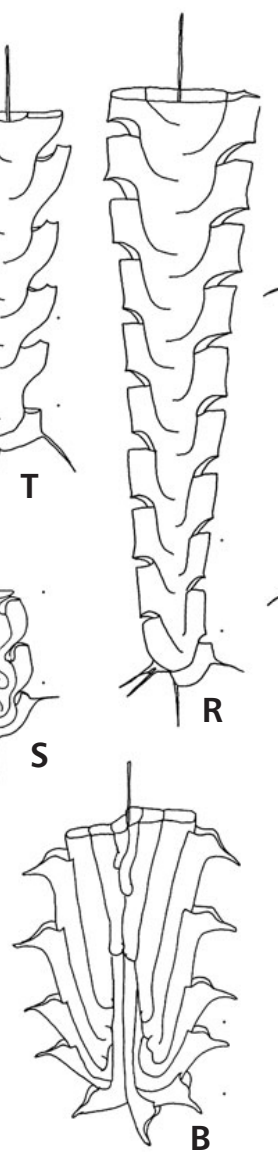
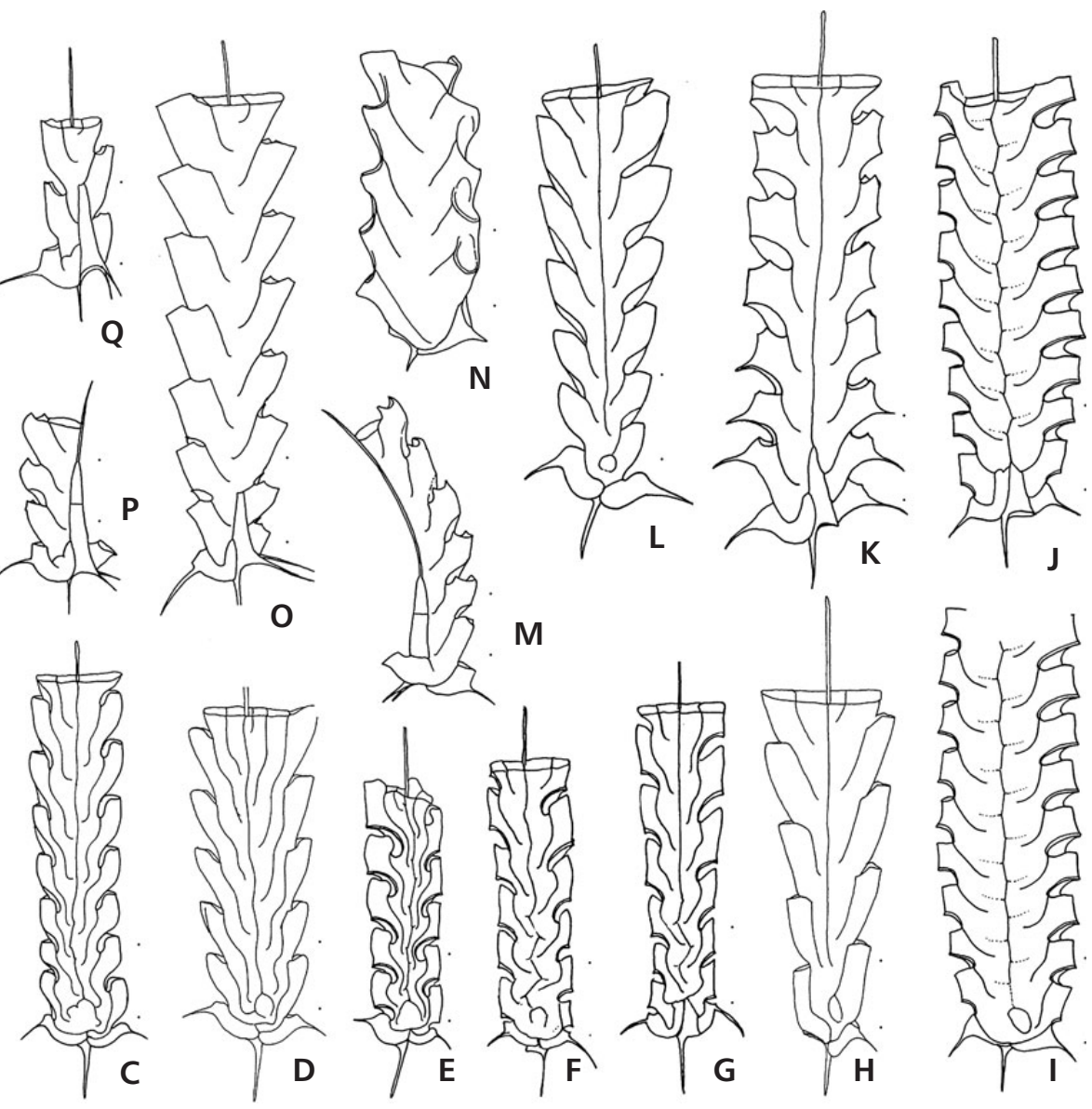

M
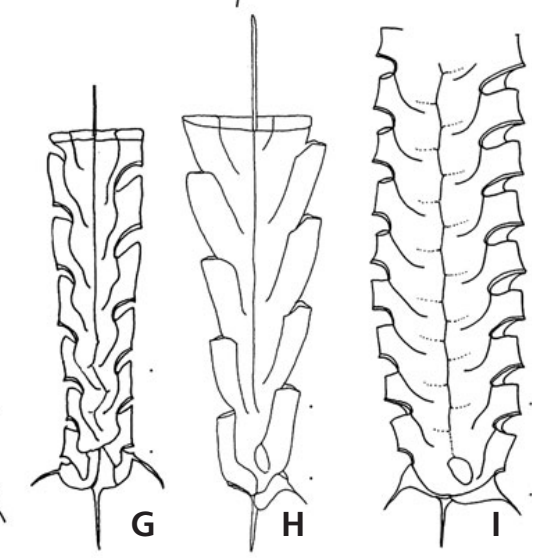

Figure 19. Examples of Diplograptidae. $\bullet \mathrm{A}, \mathrm{B}-$ Apiograptus $\mathrm{sp} \cdot \bullet \mathrm{C}, \mathrm{S}-$ Levisograptus austrodentatus (Harris \& Keble). D - Levisograptus dentatus (Brongniart). $\bullet \mathrm{E}-$ Levisograptus primus (Legg). $\bullet \mathrm{F}, \mathrm{G}-$ Archiclimacograptus $\mathrm{sp} . \bullet \mathrm{H}-$ Eoglyptograptus gerhardi $\mathrm{Maletz} \cdot \bullet \mathrm{I}, \mathrm{J}-$ Pseudamplexograptus distichus (Eichwald). $\bullet \mathrm{K}-$ Oepikograptus bekkeri (Öpik). $\bullet \mathrm{L}-$ Hustedograptus $\mathrm{sp} . \bullet \mathrm{M}, \mathrm{P}-$ Peiragraptus fallax Strachan. $\bullet \mathrm{N}-$ Diplograptus pristis (Hisinger). $・ \mathrm{O}-$ Rectograptus $\mathrm{sp} . \bullet \mathrm{Q}, \mathrm{T}-$ Anticostia $\mathrm{sp} . \bullet \mathrm{R}-$ Amplexograptus praetypicalis Riva. $\bullet \mathrm{U}-$ Arnheimograptus anacanthus $($ Mitchell \& Bergström). A, C-F, H, I, L-N, R-U in reverse view, rest obverse view. Reconstructions (JM) based on various sources. The scale is shown by two dots at a distance of $1 \mathrm{~mm}$ close to each specimen.

biserial taxa might be necessary to find a solution. Diplograptidae is a paraphyletic family from which Lasiograptidae, Dicranograptidae and possibly the Climacograptidae originated independently (Fig. 17).

The concept of the family Diplograptidae has changed considerably during the time of its use. Lapworth (1873b) introduced the taxon for biserial, dipleural graptolites, but the author stated that this arrangement was provisionally and essentially artificial. As used by Mitchell et al. (2007), it includes most of the Orthograptidae of Mitchell (1987), except for the Lasiograptinae, now recognized as the family Lasiograptidae (Mitchell et al. 2007). Even though a number of taxa are well known from isolated material, many questions still remain regarding the internal structure of Diplograptidae.

Mitchell et al. (2009) revised the genus Diplograptus M'Coy (Fig. 19N), the name giver to Diplograptidae and showed it to nest among the main plexus of the Orthograptidae of Mitchell (1987), a clade of biserials with a pat- tern $\mathrm{G}$ astogeny (Fig. 18G) or one derived from a pattern $\mathrm{G}$ astogeny and possessing distinct paired antivirgellar spines. Except for the proximal end pattern, the genus might better be placed with the archiclimacograptids as was stated by the authors. The inclusion among the derived orthograptids in their analysis may be seen as a result of the simplified proximal development type leading to wrong conclusions due to the lack of sufficient characters for a proper taxonomic resolution. It is here suggested to interpret Diplograptus as a derived diplograptid with its ancestry among the archiclimacograptids due to the lack of antivirgellar spines, the relatively short sicula and the simple thecal style.

Subfamily Orthograptinae Mitchell, 1987 (p. 380) (incl. Peiragraptinae Jaanusson, 1960, p. 322)

Diagnosis. - (Mitchell, 1987, p. 380) Aseptate to septate 
species with straight median septum; pattern A or pattern $G$ astogeny; strongly asymmetrical proximal end with sicula extensively exposed on obverse side; sicula commonly bearing paired antivirgellar spines.

Genera included. - Amplexograptus Elles \& Wood, 1907 (Fig. 19R); Anticostia Stewart \& Mitchell, 1997 (Fig. 19Q, T); Arnheimograptus Mitchell, 1987 (Fig. 19U); Ceramograptus Hudson, 1915; Geniculograptus Mitchell, 1987; Hustedograptus Mitchell, 1987 (Figs 18A, 19L); Orthograptus Lapworth, 1873 (Fig. 18G); Orthoretiograptus Mu, 1977 in Wang \& Jin (1977); Pacificograptus Koren', 1979; Paraorthograptus Mu et al., 1974; Pararetiograptus Mu et al., 1974; Peiragraptus Strachan, 1954 (Fig. 19M, P); Pseudoreteograptus Mu, 1993 in Mu et al. (1993); Rectograptus Přibyl, 1949 (Fig. 190); Uticagraptus Riva, 1987.

Discussion. - Mitchell (1987) introduced the Orthograptidae with three subfamilies, Orthograptinae Mitchell, 1987, Peiragraptinae Jaanusson, 1960 and Lasiograptinae Lapworth, 1879. He included only the genera Orthograptus and Hustedograptus in the subfamily Orthograptinae.

Family Lasiograptidae Lapworth, 1880e (p. 188) (incl. Archiretiolitinae Bulman, 1955, p. 88)

Diagnosis (emended). - Biserial, dipleural axonophorans; metasicular origin of th $1^{1}$; proximal end square to highly asymmetrical, generally provided with a virgellar spine and paired antivirgellar spines; proximal development type poorly known due to attenuation of fusellum in most taxa, but assumed to be of derived pattern $\mathrm{G}$ astogeny (Mitchell 1987, Mitchell et al. 2007); simple to progressively more complex development of lacinia.

Genera included. - Arachniograptus Ross \& Berry, 1963; Archiretiolites Eisenack, 1935; Brevigraptus Mitchell, 1988; Hallograptus Lapworth, 1876a; Lasiograptus Lapworth, 1873; Neurograptus Elles \& Wood, 1908; Nymphograptus Elles \& Wood, 1908; Orthoretiolites Whittington, 1954; Paraplegmatograptus Mu \& Lin, 1984; Phormograptus Whittington, 1955; Pipiograptus Whittington, 1955; Plegmatograptus Elles \& Wood, 1908; Sunigraptus Mu, 1993 in Mu et al. (1993); Tysanograptus Elles \& Wood, 1908; Yangzigraptus Mu, 1983 in Yang et al. (1983); Yinograptus Mu, 1962 in Mu \& Chen (1962).

Discussion. - Lasiograptidae appears to be a monophyletic clade originating from a diplograptid ancestor. Mitchell et al. (2007, p. 336) recognized Lasiograptidae as a wellsupported clade in their analysis. The group includes also Archiretiolitinae, referred to the Retiolitidae by Bulman
(1955, 1970). The authors (Mitchell et al. 2007, p. 337) referred to Hallograptus mucronatus Hall as the earliest taxon of the Lasiograptidae. It has a pattern A astogeny (Fig. 18A) and not the derived pattern $G$ astogeny (Fig. 18G) of later lasiograptids, including Lasiograptus. The clade is not well supported by structural data as the proximal development of many of the highly reticulate taxa is virtually unknown and cannot be compared with that of the Hallograptus/Lasiograptus group of taxa. Mitchell et al. (2007, text-fig. 1B) labeled the proximal development pattern as pattern $\mathrm{L}$, but did not describe it.

Family Climacograptidae Frech, 1897 (p. 607)

(ex Familie Climacograptidi Frech, 1897)

(= Superfamily Climacograptoidea Frech sensu Štorch et al. 2011, p. 353)

Diagnosis. - Biserial, dipleural axonophorans; metasicular origin of th $1^{1}$; proximal end square to highly asymmetrical, generally provided with a virgellar spine as the only proximal spine, but secondarily there is development of thecal spines on the first thecal pair; proximal development type of pattern C astogeny (Mitchell et al. 2007) and progressively more simple; thecae with distinct geniculum; intrathecal folds and complete, often strongly zigzag shaped median septum in earlier taxa, parasiculae and parathecae common.

Genera included. - Appendispinograptus Li \& Li, 1985; Clathrograptus Lapworth, 1873; Climacograptus Hall, 1865; Diplacanthograptus Mitchell, 1987 (Fig. 20K-N), Ensigraptus Riva, 1989 in Riva \& Ketner (1989); Euclimacograptus Riva, 1989 in Riva \& Ketner (1989); Gymnograptus Bulman, 1953; Haddingograptus Maletz, 1997 (Fig. 20C-F), Idiograptus Lapworth, 1880; Leptothecalograptus Li, 2002 in Mu et al. (2002); Mendograptus Rusconi 1948; Notograptus Rusconi 1948; Oelandograptus Mitchell, 1987 (Fig. 20A); Proclimacograptus Maletz, 1997 (Fig. 20G, H); Prolasiograptus Lee, 1963 (Fig. 20I, P); Pseudoclimacograptus Přibyl, 1947 (Fig. 20O, Q); Reteograptus Hall, 1859 (= Retiograptus Hall, 1865); Styracograptus Štorch et al., 2011 (Fig. 20J); Undulograptus Bouček, 1973 (Fig. 20B).

Discussion. - The derived members of Climacograptidae may represent a monophyletic clade, as discussed by Storch et al. (2011), who referred to the unpublished analysis of Cone (2004) to support their claim. Details of the origin and early taxa of the group are difficult to obtain and Mitchell et al. (2007) identified early biserials (e.g. Undulograptus, Archiclimacograptus) as stem group Diplograptoidea. The authors identified the archiclimacograptids as clearly paraphyletic. Maletz (2011b, figs 2, 3) without 

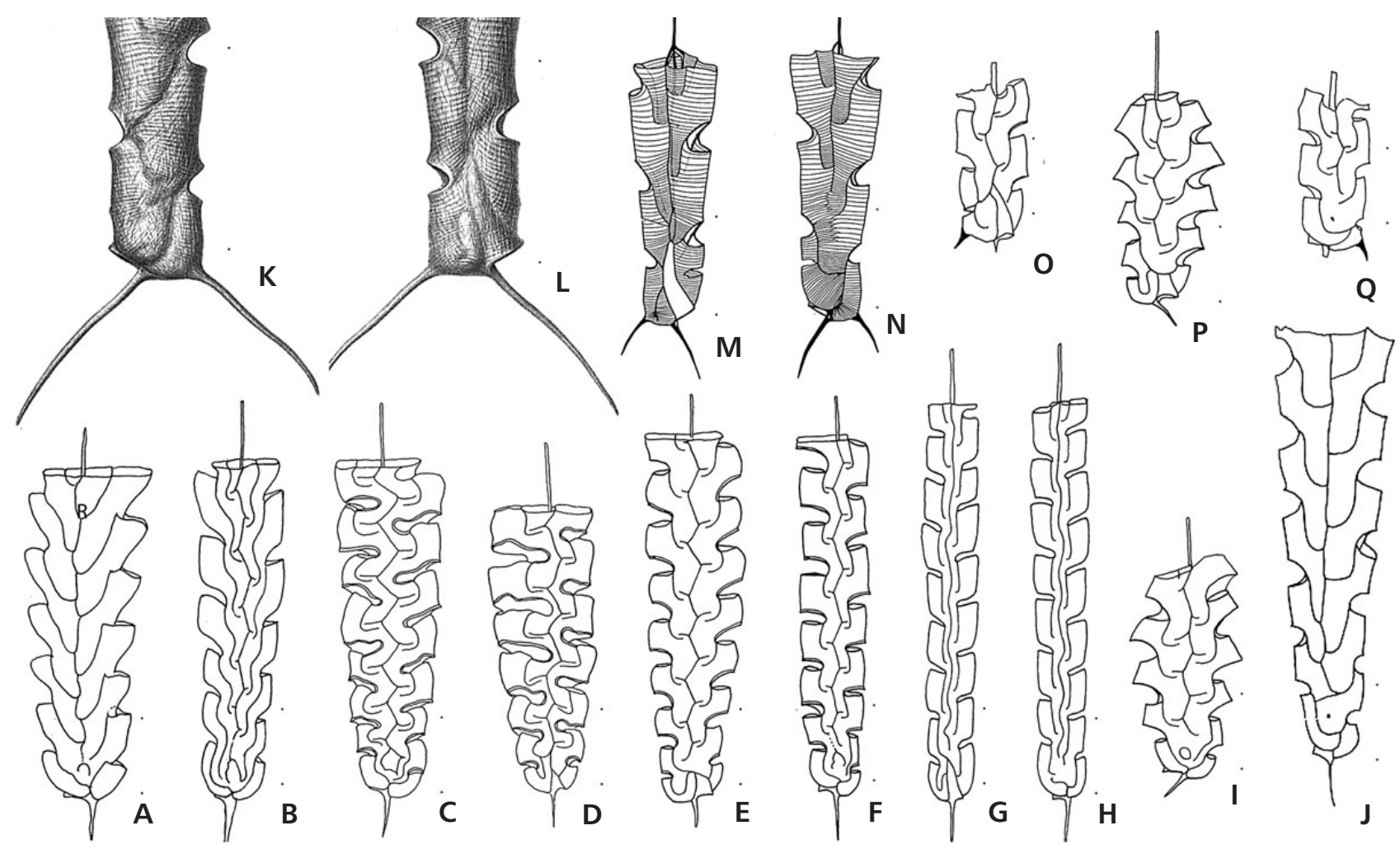

Figure 20. Climacograptidae. • A - Oelandograptus oelandicus (Bulman). • B - Undulograptus formosus (Mu \& Lee). • C, D - Haddingograptus oliveri (Bouček). • E, F - Haddingograptus intermedius (Berry). $\bullet \mathrm{G}, \mathrm{H}-$ Proclimacograptus angustatus $($ Ekström). $・ \mathrm{I}, \mathrm{P}-$ Prolasiograptus haplus (Jaanusson). $\bullet \mathrm{J}-$ Styracograptus tubuliferus (Lapworth). $\bullet \mathrm{K}-\mathrm{N}-$ Diplacanthograptus spiniferus (Ruedemann) (K, L from Bulman 1932, showing cortical bandages). $\bullet \mathrm{O}, \mathrm{Q}-$ Pseudoclimacograptus scharenbergi (Lapworth). A-C, F, H-K, N, Q in reverse view, rest obverse view. Reconstructions (JM) based on various sources. The scale is shown by two dots at a distance of $1 \mathrm{~mm}$ close to each specimen.

re-analyzing the climacograptids, provided two alternatives for the interpretation of early climacograptids (archiclimacograptids), but was unable to resolve the problems of early climacograptid evolution. His alternate interpretation (Maletz 2011b, fig. 3) suggested an early differentiation of the climacograptids from Undulograptus and a separate and independent evolution of the archiclimacograptids.

Climacograptidae originally included Climacograptus, Dicranograptidae and Glossograptidae, and also the genus Monoclimacis and was based entirely on the "climacograptid" (geniculate) thecal outline (Frech 1897). Bulman (1955, 1970) included Climacograptus in Diplograptidae, while Storch et al. (2011) in the latest revision referred the "climacograptids" (now split into a number of genera) to the superfamily Climacograptoidea. The origin and early evolution of the climacograptids is still speculative (cf. Fig. 21) and uncertain as is seen from the interpretation in Maletz (2011b, fig. 3) deriving Pseudoclimacograptus and its descendants from an ancestor such as Haddingograptus, a genus without the typical proximal spines of Archiclimacograptus and derived taxa.

Štorch et al. (2011, fig. 6) discussed Undulograptus formosus $\mathrm{Mu} \&$ Lee as the earliest member of the Neograptina, and, thus, Normalograptidae. The early taxa
Undulograptus, Oelandograptus and Proclimacograptus are here regarded as early members of Climacograptidae, however (see discussion under Neograptina) and may have to be removed from the Neograptina as shown in Fig. 17.

Family Dicranograptidae Lapworth, 1873b

(table facing p. 555)

(= Superfamily Dicranograptacea Lapworth, 2007

in Mitchell et al. 2007

[misspelled Dicranograptacae in fig. 1];

= Superfamily Dicranograptoidea Lapworth, 1873

in Štorch et al. 2011)

Diagnosis. - Biserial, dipleural axonophorans, secondarily two-stiped or partly two-stiped, uniserial, or with cladial branching; proximal end with metasicular origin of th $1^{1}$; proximal end provided with a virgellar spine and additional apertural spines on the first thecal pair at least; proximal development type of derived pattern A astogeny (see Mitchell 1987); thecae variable, often geniculate and with isolated, introverted apertures; intrathecal folds and complete median septum in biserial taxa, lost in some younger taxa with shortened thecal overlap and thecal simplification. 


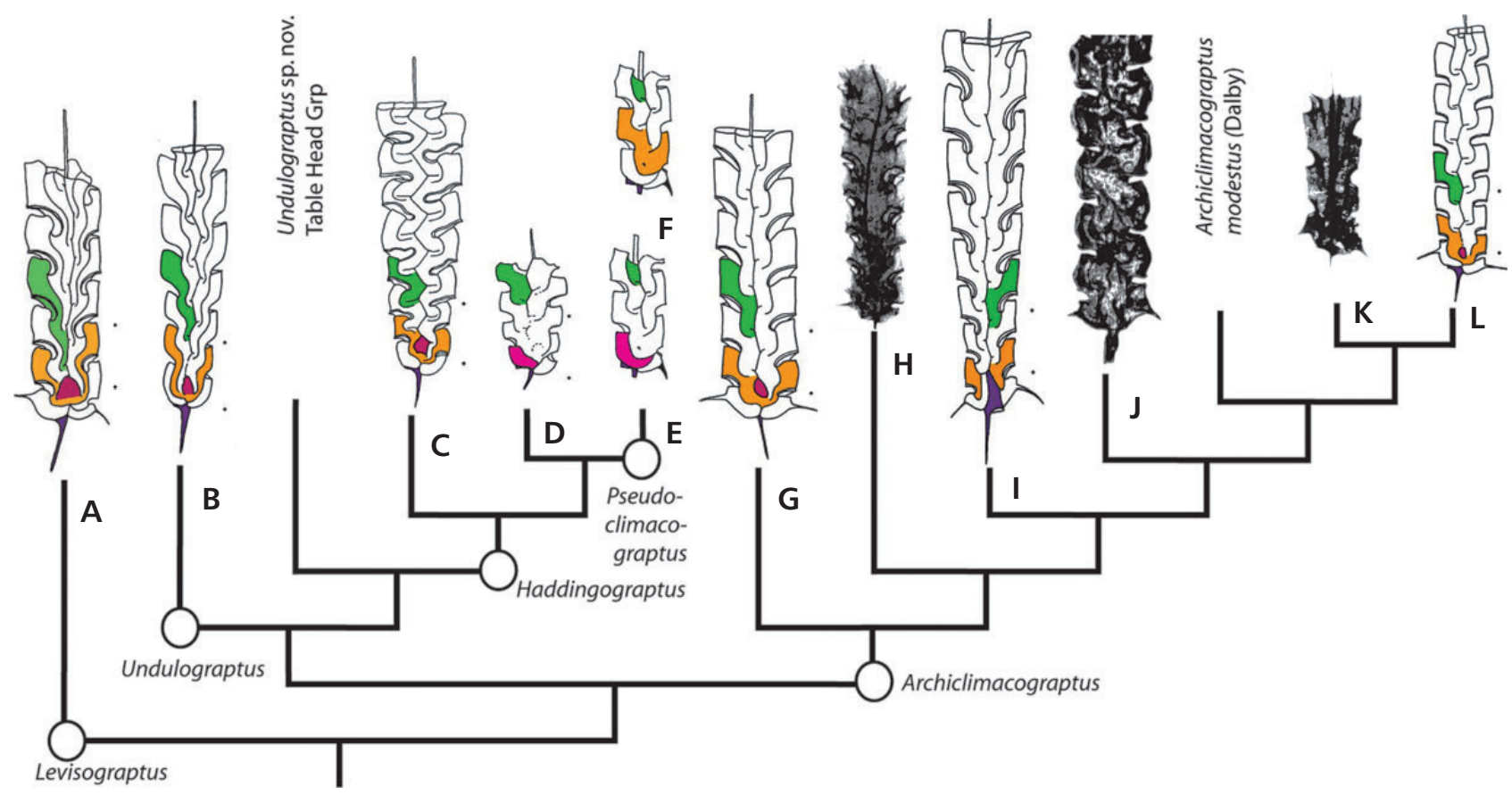

Figure 21. Origin of Climacograptidae, alternative interpretation of Maletz (2011b, fig. 3). A - Levisograptus primus. $\bullet$ B - Undulograptus formosus. $\cdot \mathrm{C}-$ Haddingograptus oliveri. $\bullet \mathrm{D}-$ Haddingograptus eurystoma (Jaanusson). $\bullet \mathrm{E}, \mathrm{F}-$ Pseudoclimacograptus scharenbergi. $\bullet \mathrm{G}-$ Archiclimacograptus modicellus (Harris \& Thomas). $-\mathrm{H}$ - Archiclimacograptus decoratus (Harris \& Thomas). - I - Archiclimacograptus sebyensis (Jaanusson). $\cdot \mathrm{J}$ - Archiclimacograptus $\mathrm{sp} \cdot \bullet \mathrm{K}-$ Archiclimacograptus skagensis (Jaanusson \& Skoglund). $\bullet \mathrm{L}$ - Archiclimacograptus meridionalis (Ruedemann).

Discussion. - Dicranograptidae is considered to be a monophyletic clade with its members showing a quite variable colony shape from multiramous to one-stiped (Fig. 22). A number of taxa even show a secondarily multiramous colony with cladial distal branchings. They are all related through a number of proximal end characters or homologies on the sicula and the first thecal pairs (see Mitchell 1987, Mitchell et al. 2007). The precise origin and early evolution of the group is uncertain. Mitchell et al. (2007) included the biserial, dipleural Dicaulograptus hystrix as a basal member of Dicranograptidae. Maletz (1998, p. 114) suggested a possible origin of the dicranograptids through Undulograptus sinicus $\mathrm{Mu} \&$ Lee (Levisograptus sinicus in Maletz 2011a), as indicated by the presence of the earliest two-stiped dicellograptids such as Levisograptus dicellograptoides Maletz (Maletz 1998) and Undulograptus sp. nov. (Kraft \& Kraft 2003) in the lower Darriwilian.

Subfamily Dicranograptinae Lapworth, 1873b (table 1, facing p. 555)

Diagnosis (revised). - Biserial, dipleural axonophorans, secondarily two-stiped or partly two-stiped, uniserial, or with cladial branching; proximal end with metasicular origin of th $1^{1}$; proximal end provided with a virgellar spine and additional apertural spines on the first thecal pair at least; proximal development type of derived pattern A as- togeny (see Mitchell 1987); thecae variable, often geniculate and with isolated introverted apertures; intrathecal folds and complete median septum in biserial taxa.

Genera included. - Aclistograptus Ge, 2002 in $\mathrm{Mu}$ et al. (2002); Amphigraptus Lapworth, 1873 (Fig. 22D); Cladograpsus Emmons, 1855; Cladograpsus Carruthers, 1858 (non Cladograpsus Geinitz, 1852: syn. of Didymograptus); Clematograptus Hopkinson, 1875 in Hopkinson \& Lapworth (1875); Deflexigraptus $\mathrm{Mu}, 2002$ in $\mathrm{Mu}$ et al. (2002); Dicaulograptus Rickards \& Bulman, 1965; Dicellograpsus Hopkinson, 1871 (Fig. 22C); Diceratograptus Mu, 1963; Dicranograptus Hall, 1865 (Fig. 22A, B, E); Incumbograptus Ge, 2002 in Mu et al. (2002); Jiangxigraptus Yu \& Fang, 1966; Leptograptus Lapworth, 1873; Ningxiagraptus Ge, 2002 in $\mathrm{Mu}$ et al. (2002); Pseudazygograptus Mu, Lee \& Geh, 1960; Syndyograptus Ruedemann, 1908; Tangyagraptus Mu, 1963.

Discussion. - Dicranograptinae is a paraphyletic group of taxa from which the Nemagraptinae originated through a number of changes in the proximal end of the colony. Several dicranograptine genera developed single (Tangyagrap$t u s$ ) or even paired (Amphigraptus) cladia along the stipes as a secondary branching style independently from the cladial evolution in the genus Nemagraptus. The biserialuniserial rhabdosome shape of Dicranograptus appears to be a secondary development, originating through a di- 

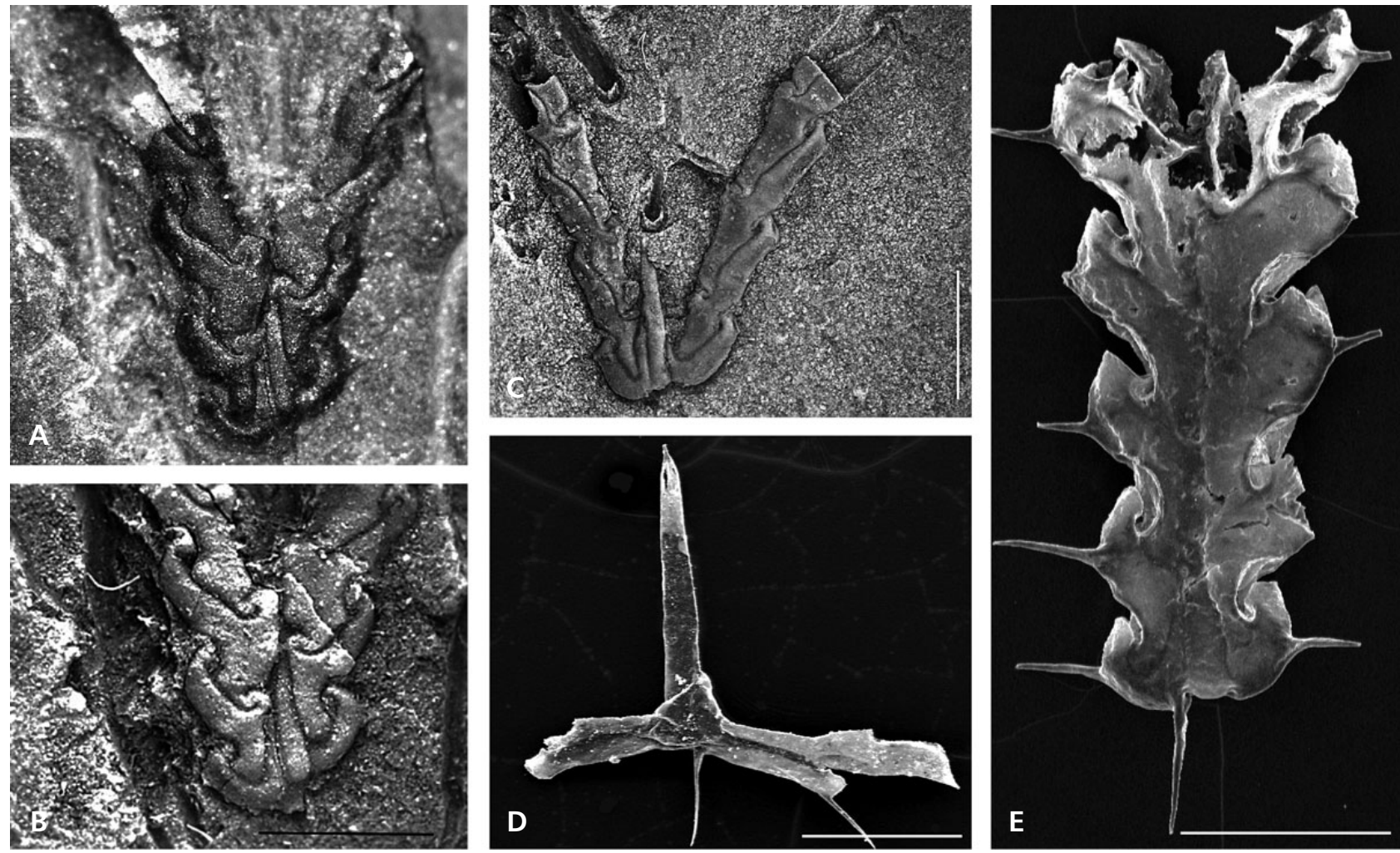

Figure 22. Examples of Dicranograptidae. • A, B - Dicranograptus irregularis Hadding, syntype LO 2432t. • C - Dicellograptus vagus Hadding, LO 2439t. • D - Amphigraptus sp., JM 94/01, early growth stage, Viola Limestone. • E - Dicranograptus sp., JM 26/17, Viola Limestone. All specimens in obverse view except for D (reverse view). Scale bar represents $1 \mathrm{~mm}$.

cellograptid ancestor. This change from uniserial to biserial-uniserial rhabdosomes and vice versa could also be interpreted as an inter-taxon variability without major taxonomic importance.

Subfamily Nemagraptinae Lapworth, $1873 b$ (p. 556) (ex Nemagraptidae Lapworth, 1873b)

Diagnosis (revised). - Secondarily two-stiped dicranograptids with or without cladial branching; proximal end with metasicular origin of th $1^{1}$; proximal end provided with a virgellar spine and additional apertural spines on the first thecal pair at least; proximal development type of pattern $\mathrm{N}$ astogeny (see Mitchell 1987); thecae variable, often geniculate and with isolated introverted apertures; intrathecal folds in some taxa.

Genera included. - Coenograptus Hall, 1868; Geitonograptus Obut \& Zubtzov, 1964; Helicograpsus Nicholson, 1868; Nemagrapsus Emmons, 1855; Ordosograptus Lin, 1980; Pleurograpsus Nicholson, 1867; Stephanograptus Geinitz, 1866.

Discussion. - Nemagraptidae has commonly been used as a taxonomic unit of the family level (e.g. Bulman 1970, Mu et al. 2002), but is here used as a subfamily to indicate its proper relationships to the dicranograptids. The Nemagraptinae originate from a dicellograptid ancestor in the late Darriwilian (see Mitchell 1987, figs 13, 17; Mitchell et al. 2007), but the transition is poorly documented. Nemagraptus linmassiae Finney, 1985 still possesses the intrathecal folds (recognized as prothecal folds in Finney 1985) as a symplesiomorphic character retained from the dicellograptids, but already shows the isolated metasicula as the main synapomorphy of the nemagraptids (Finney 1985, fig. 23). Unfortunately, this taxon is found only at a single locality and its biostratigraphical range is unknown.

Infraorder Neograptina Štorch, Mitchell, Finney \& Melchin, 2011 (p. 368)

(= Monograptidae sensu Mitchell 1987)

Definition. - (Štorch et al. 2011, p. 368) Neograptina is the total clade comprising all species sharing a more recent common ancestor with Monograptus priodon than with Diplograptus pristis (i.e., the species on the branches arising from the right side of node 1 in Fig. 6 [of Štorch et al. 2011] and all their descendants). 
Discussion. - Štorch et al. (2011) erected the monophyletic taxon Neograptina (Figs 16, 17) as a sister taxon to Diplograptina and identified Undulograptus formosus as the earliest member of the clade. The authors (Štorch et al. 2011, p. 368) provided a cladistic definition for the Neograptina, even though they called it a diagnosis.

Undulograptus is here referred to the Climacograptidae, but its precise phylogenetic relationship at the roots of Climacograptidae and Normalograptidae is uncertain (see Maletz 2011b). The origin and early evolution of proximally spineless (except for the virgella) axonophorans is completely unresolved and Maletz (2011b) suggested an origin of the climacograptids (Pseudoclimacograptus and descendants) from a proximally spineless ancestor (Fig. 21). The proximal end spines of derived climacograptids then would be secondarily derived, a suggestion that may be supported by the highly variable presence and/or position of proximal spines in derived climacograptids (see Štorch et al. 2011). If this turned out to be correct, Climacograptidae may actually be part of the Neograptina.

Neograptina, as understood here, possess a relatively narrow proximal end without spines, except for the virgella and a pattern $\mathrm{C}$ astogeny of the early members. The concept of Neograptina follows largely the ideas of Mitchell (1987) and Mitchell et al. (2007), who extended the name Monograptina to include the stem group of biserials, the normalograptids. The resulting confusion led Šrtorch et al. (2011, p. 314) to reverse this move and use the term Neograptina for the same clade. Neograptina includes here the two superfamilies Retioloidea and Monograptoidea, but Normalograptidae as a stem group have not been assigned to a superfamily.

Family Normalograptidae Štorch \& Serpagli, 1993 (p. 14) (= Normalograptoidea Mitchell et al. 2007)

Definition. - (Emended from Melchin et al. 2011, p. 293) Paraphyletic taxon that includes all members of the clade Infraorder Neograptina excluding those included herein within the clades family Neodiplograptidae, superfamily Monograptoidea and superfamily Retiolitoidea.

Genera included. - Clinoclimacograptus Bulman \& Rickards, 1968; Cystograptus Hundt, 1942; Hedrograptus Obut, 1949; ?Hirsutograptus Koren' \& Rickards, 1996; ?Limpidograptus Khaletskaya, 1962; Lithuanograptus Paskevicius, 1976; Metaclimacograptus Bulman \& Rickards, 1968; Neodicellograptus Mu \& Wang, 1977 in Wang \& Jin (1977); Neoglyptograptus Rickards et al. 1995; Normalograptus Legrand, 1987 (Fig. 23A, C, D, F); Pseudoglyptograptus Bulman \& Rickards, 1968; Retioclimacis Mu et al., 1974; Rhaphidograptus Bulman, 1936; Scalarigraptus Riva, 1988; Sichuanograptus Zhao, 1976;
Skanegraptus Maletz, 2011c (Fig. 23B); Talacastograptus Cuerda, Rickards \& Cingolani, 1988.

Discussion. - Štorch et al. (2011, p. 368) discussed the family as a paraphyletic taxon and extended it to include the basal Neograptina, but did not provide a revised diagnosis or definition. The authors erroneously included all "post-Hirnantian graptolites" in Normalograptidae in their cladogram (Štorch et al. 2011, fig. 6), even though they explicitly excluded some of them in the acompanying text. Melchin et al. (2011) provided a definition based on a cladistic analysis and stated (Melchin et al. 2011, p. 293): "As a consequence of the variety of proximal and thecal morphologies found among taxa within this stem group, it is not currently possible to identify any morphologic criteria that can be used to uniquely characterize this taxon."

Normalograptidae represents a paraphyletic family with roots in the early Darriwilian (Middle Ordovician). The precise origin and evolution of the early Normalograptidae and the differentiation from Climacograptidae is unclear (Maletz 2011c). The first taxon with a proximal end pattern similar to proximal development type $\mathrm{H}$ is Skanegraptus (Fig. 23B), but this still has a number of characters similar to those of a pattern $\mathrm{C}$ astogeny and its evolutionary origin is uncertain (Maletz 2011c). As Maletz (2011b) provided an alternative for the evolutionary relationships of the early Climacograptidae (Fig. 21), the origin of Normalograptidae may have to be re-evaluated and it is preferred here to base them on the origin of a pattern $\mathrm{H}$ astogeny for the moment, instead of including taxa with a pattern $\mathrm{C}$ astogeny and without proximal spines except for the virgella (e.g. Haddingograptus, Oelandograptus, Proclimacograptus, Undulograptus). The evolutionary relationships of these are uncertain and pattern $\mathrm{H}$ astogeny may have evolved several times independently (see Maletz 2011c). The origin of Neograptina from within a paraphyletic Diplograptina, however, is quite likely.

Family Neodiplograptidae Melchin, Mitchell, Naczk-Cameron, Fan \& Loxton, 2011 (p. 296)

Definition. - (Melchin et al. 2011, p. 296) The partial clade that includes the most recent common ancestor of Metabolograptus ojsuensis (Koren' \& Mikhaylova) and Retiolites geinitzianus (Barrande) but excluding those taxa included in the Family Retiolitidae.

Subfamily Neodiplograptinae Melchin, Mitchell, Naczk-Cameron, Fan \& Loxton, 2011 (p. 296)

Definition. - The partial clade that includes the most recent common ancestor of Metabolograptus ojsuensis and Retio- 

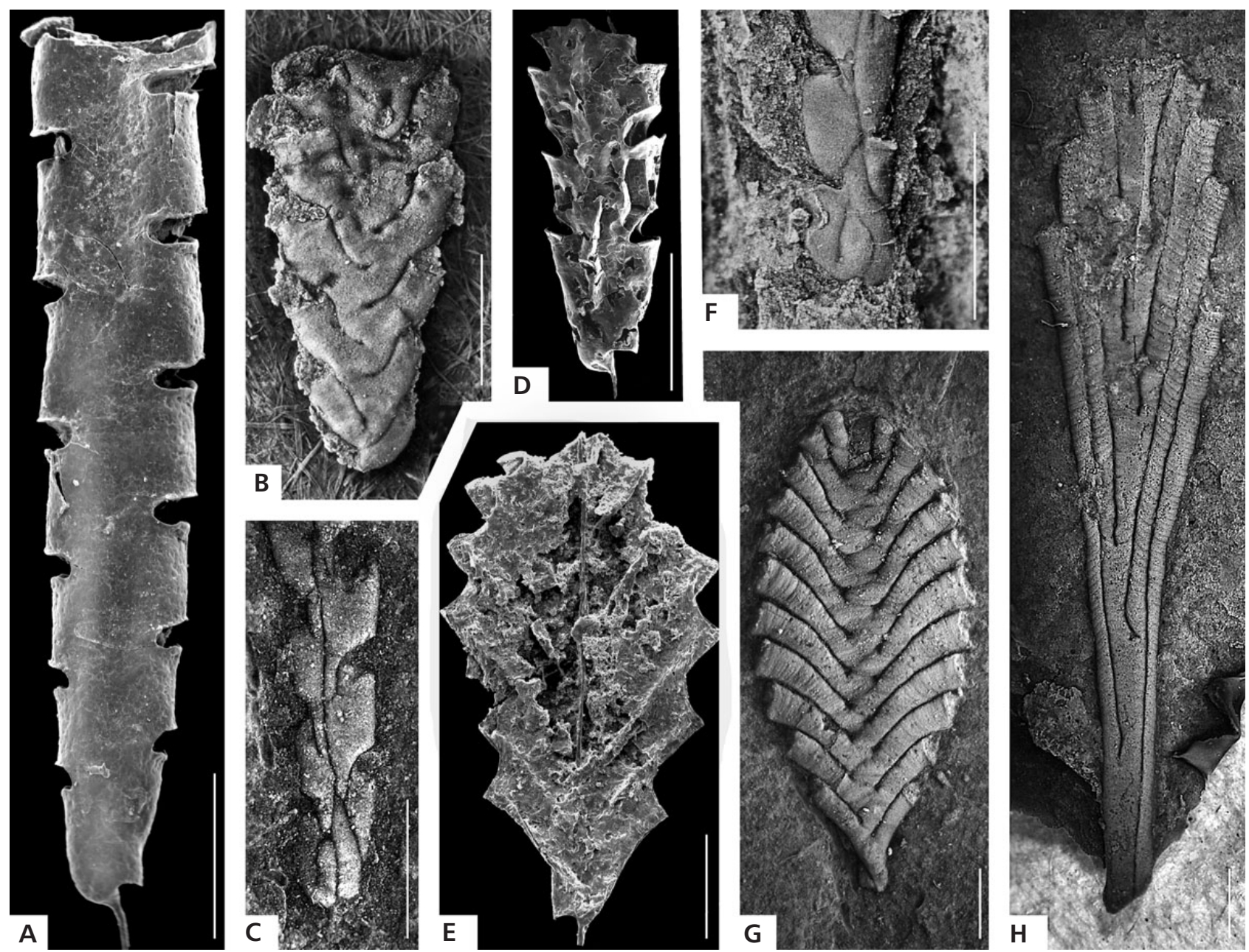

Figure 23. Examples of biserial Neograptina. • A - Normalograptus scalaris (Hisinger), NMW 2002/19G.4C. • B - Skanegraptus janus Maletz, LO 11196T. • C - Normalograptus brevis (Elles \& Wood), LO 2407t. • D - Normalograptus sp., JM 05/1. • E - Parapetalolithus sp. OSM-4-1-07. $\cdot \mathrm{F}$ - Normalograptus antiquus (Ge), PMO 138.625. $\bullet \mathrm{G}-$ Petalolithus minor, LO 1115t. $\bullet \mathrm{H}$ - Cephalograptus cometa (Geinitz), LO $1120 \mathrm{t}$, latex cast. Scale bar represents $1 \mathrm{~mm}$.

lites geinitzianus but excluding those taxa included in the Family Retiolitidae and the subfamily Petalolithinae.

Genera included. - Korenograptus Melchin et al., 2011; Metabolograptus Obut \& Sennikov, 1985; Neodiplograptus Legrand, 1987; Paraclimacograptus Přibyl, 1948b; Persculptograptus Koren’ \& Rickards, 1996; Rickardsograptus Melchin et al., 2011.

Discussion. - The taxon is paraphyletic (Fig. 17), based on the definition by Melchin et al. (2011, p. 296). It is suggested here to keep Petalolithinae as a separate subfamily in the Neodiplograptidae, from which they undoubtedly originated (see Melchin et al. 2011) and not include them in Retiolitidae. Therefore, a subfamily Neodiplograptinae has been established. Neodiplograptidae then should be excluded from the Retioloidea and referred as a family rank taxon of the Neograptina.
Subfamily Petalolithinae Bulman, 1955 (p. 87)

(nom. correct. Melchin et al. 2011, p. 298

from Petalograptinae Bulman, 1955)

Definition. - (Emended from Melchin et al. 2011, p. 298) The partial clade that includes the first species that acquired a unistipular (aseptate) biserial rhabdosome in the clade that contains Paramplexograptus madernii (Koren' \& Mikhaylova) and Retiolites geinitzianus and its descendants, but excluding the taxa included in the Family Retiolitidae.

Genera included. - Agetograptus Obut \& Sobolevskaya in Obut et al., 1968; Cephalograpsus Hopkinson, 1869 (Fig. 23H); Comograptus Obut \& Sobolevskaya, 1968 in Obut et al. (1968); Corbograptus Koren' \& Rickards, 1996; Demicystifer Hundt, 1959; ?Demicystograptus Hundt, 1950; Dimorphograptoides Koren’ \& Rickards, 
1996; Diprion Barrande, 1850 (non Diprion Schrank, 1802 [Hymenoptera]); Dittograptus Obut \& Sobolevskaya, 1968 in Obut et al. (1968); Glyptograptus Lapworth, 1873; Hercograptus Melchin, 1999; Paramplexograptus Melchin et al., 2011; Parapetalolithus Koren' \& Rickards, 1996 (Fig. 23E); Petalograptus Suess, 1851; Petalolithus Suess, 1851 (Fig. 23, G), Pseudorthograptus Legrand, 1987 (?Fig. 24C); Rivagraptus Koren' \& Rickards, 1996; Songxigraptus Fang, Liang \& Yu, 1990; Spinadiplograptus Hundt, 1965; Sudburigraptus Koren' \& Rickards, 1996; Victorograptus Koren' \& Rickards, 1996.

Discussion. - Melchin et al. (2011) defined Petalolithinae as a paraphyletic taxon and revised the name of the subfamily, referring to the genus Petalolithus, one of the few genera without the typical graptolite genus ending -graptus. Bulman (1970) did not refer to the Petalolithinae, but included Petalograptus (now Petalolithus: see Loydell 1993, p. 36) in Diplograptidae.

A number of species of the genera included here in Petalolithinae (ancorate petalolithids in KozłowskaDawidziuk et al. 2003) bear a four-pronged ancora, typical of the Retiolitidae, and Hercograptus even has a special development of an ancora sleeve. Thus, these taxa may have to be included in Retiolitidae as done by Kozłowska-Dawidziuk et al. (2003), cutting down on the taxa included in Neodiplograptidae (Petalolithinae) as used herein (Fig. 17B).

Superfamily Retiolitoidea Lapworth, 1873b

(table 1 facing p. 555) (emend. Melchin et al. 2011, p. 296)

(non Retiolitoidea Kozłowska-Dawidziuk,

Lenz \& Bates, 2003, p. 565)

Diagnosis (emended). - Axonophorans (Neograptina) with scandent, biserial, dipleural rhabdosome; normally preserved as a framework of lists formed of cortical bandages; a combination of the thecal framework lists joined with the ancora sleeve, a distal development of the ancora umbrella; fusellum rarely preserved, but fragments of fuselli generally preserved along list seams; sicula preserved in earlier taxa, but reduced and lacking in younger forms; list surfaces seamed inside; smooth, longitudinally striated, or pustulose.

Discussion. - The taxon was originally spelled Retioloidea by Lapworth (1873b). Kozłowska-Dawidziuk et al. (2003) named the presence of the ancora umbrella as the defining synapomorphy of their superfamily Retiolitoidea, which included also the ancorate petalolithids. Melchin et al. (2011, p. 296) provided a cladistic definition for the emended taxon Retiolitoidea including the Neodiplograptidae and Petalolithinae, extending considerably the concept of the Retiolitoidea Lapworth (Fig. 17A). Melchin et al. (2011) stated the presence of several synapomorphies appearing near the base of the Retiolitoidea, with the "presence of inclined distal thecal subapertural walls and interthecal septa", a character difficult to observe in most flattened material and likely to be modified by compaction of specimens on shale surfaces. The concept of the Retiolitoidea has been changed considerably from what is generally understood as a retiolitid and their relatives by adding a number of taxa that do not even bear indications of an ancora. It thus differs even from the concept of Kozłowska-Dawidziuk et al. (2003) in which only ancorate taxa are included and a number of new subfamilies are introduced for the Retiolitidae. It might actually be better to include in the Retiolitoidea only taxa with an ancora and a reduction of the fusellum as the inclusion of non-ancorate "typical" axonophorans is misleading in a similar way as the extended Monograptidae of Mitchell (1987).

Family Retiolitidae Lapworth, 1873b

(table 1 facing p. 555) (non Melchin et al. 2011)

Diagnosis (emended). - Axonophorans (Neograptina) with scandent, biserial, dipleural rhabdosome; normally preserved as a framework of lists formed of cortical bandages; a combination of the thecal framework lists joined with the ancora sleeve, a distal development of the ancora umbrella; fusellum rarely preserved, but fragments of fuselli generally preserved along list seams; sicula preserved in earlier taxa, but reduced and lacking in younger forms; list surfaces seamed inside; smooth, longitudinally striated, or pustulose.

Discussion. - Melchin et al. (2011, p. 300) defined the clade (named Retiolitinae) as "the first ancora-bearing graptolite species within the clade that includes Retiolites geinitzianus that acquired thecae constructed of a full framework of lists and reduced or absent fusellar walls, and all of its descendants" as a monophyletic clade. The authors included Petalolithinae in Retiolitidae, but it is here preferred to keep them in Neodiplograptidae as a subfamily and use Retiolitidae in the established way following Bulman $(1955,1970)$ and Bates et al. (2005). The precise definition of Retiolitidae has become rather blurred in recent literature as early ancorate and even ancora sleeve bearing taxa are excluded or included and the family extended in some cases ( $c f$. Kozłowska-Dawidziuk et al. 2003, Kozłowska-Dawidziuk 2004, Bates et al. 2005, Melchin et al. 2011). The preliminary solution proposed here (Fig. 21B) might have to be revised in the light of the interpretation of characteristic homologous features in some Petalolithinae.

Lenz \& Melchin (1987) found the surface sculptures on the retiolitid lists to be diagnostic for the subfamilies 

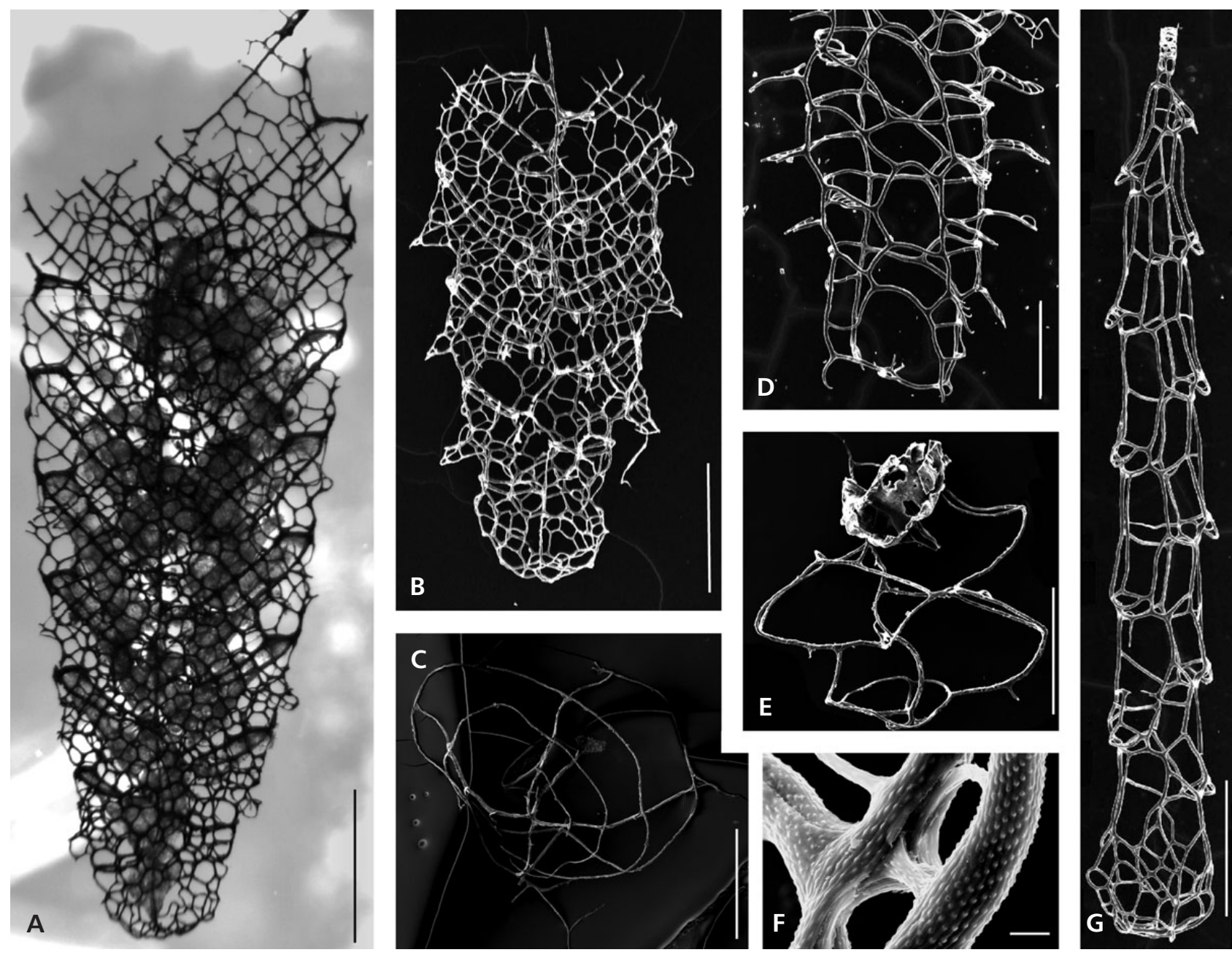

Figure 24. Examples of ancorate Petalolithinae and Retiolitidae. $・$ A, B - Retiolites geinitzianus Barrande, SMF.XXIV450, JM 85/04, A showing preservation of thecae. $\bullet$ C - ?Pseudorthograptus sp., Kal11-1-10, ancora umbrella from the outside. $\bullet$ D - Plectograptus macilentus (Törnquist), MB.G.1081. E. Rotaretiolites sp., Osm12-1-1a. • F-pustulose surface of bandages in plectograptines. $\bullet$ G - Neogothograptus balticus (Eisenack), MB.G.1082. All are chemically isolated specimens.

Retiolitinae and Plectograptinae. An earlier cladistic interpretation of the Retiolitidae by Lenz \& Melchin (1997) recognized the Retiolitinae and Plectograptinae as monophyletic taxa and a stem-group taxon Pseudoretiolites, but included "Rotaretiolites" and Rotaretiolites as basal members in the Plectograptinae. In the accompanying diagram (Lenz \& Melchin 1997, fig. 4), however, the retiolitines (in black) are shown as a paraphyletic group from which the monophyletic plectograptines originate.

Subfamily Retiolitinae Lapworth, 1873 b

(table 1 facing p. 555) (non Melchin et al. 2011, p. 300)

Diagnosis (emended). - Retiolitids with smooth or longitudinally striated lists.

Genera included. - Dabashanograptus Ge, 1990; Dimykte- rograptus Haberfelner, 1936; Eiseligraptus Hundt, 1965; Eorograptus Sennikov, 1984; Gladiograptus Lapworth, 1875 in Hopkinson \& Lapworth (1875); Gladiolites Barrande, 1850 [suppressed ICZN 1954c]; Pileograptus Lenz \& Kozłowska, 2007; Pseudoplegmatograptus Přibyl, 1948b; Pseudoretiolites Bouček \& Münch, 1944; Retiolites Barrande, 1850 (Fig. 24A, B); Rotaretiolites Bates \& Kirk, 1992 (Fig. 24E); Sinostomatograptus Huo, 1957; Stomatograptus Tullberg, 1883; Tscharyschograptus Sennikov, 1984.

Discussion. - Melchin et al. (2011) referred all retiolitids to Retiolitinae and did not differentiate Retiolitinae and Plectograptinae of previous authors (e.g. Bouček \& Münch 1952, Bates et al. 2005). Thus, the concept is identical to the Retiolitidae of other authors. Retiolitinae as used herein is a paraphyletic taxon from which the Plectograptinae were derived. 
Subfamily Plectograptinae Bouček \& Münch, 1952 (p. 10) [p. 110, English text] (Fig. 24D, F, G)

Diagnosis (emended). - Retiolitids with pustulose lists.

Genera included. - Agastograptus Obut \& Zaslavskaya, 1983; Baculograptus Lenz \& Kozłowska-Dawidziuk, 2002; Balticograptus Bouček \& Münch, 1952; Cometograptus Kozłowska-Dawidziuk, 2001; Doliograptus Lenz \& Kozłowska-Dawidziuk, 2002; Eisenackograptus Kozłowska-Dawidziuk, 1990; Giganteograptus Lenz \& Kozłowska, 2007; Gothograptus Frech, 1897; Holoretiolites Eisenack, 1951; Kirkigraptus Kozłowska \& Bates, 2008; Mirorgraptus Lenz \& Kozłowska, 2007; Neogothograptus Kozłowska-Dawidziuk, 1995 (Fig. 24F, G); Papiliograptus Lenz \& Kozłowska, 2002; Paraplectograptus Přibyl, 1948a; Plectodinemagraptus Kozłowska-Dawidziuk, 1995; Plectograptus Moberg \& Törnquist, 1909 (Fig. 24D); Pseudoplectograptus Obut \& Zaslavskaya, 1983; Quattuorgraptus Dobrowolska, 2013; Reticuloplectograptus Kozłowska, Bates \& Piras, 2010; Sagenograptoides Lenz \& Kozłowska, 2010; Sagenograptus Lenz \& KozłowskaDawidziuk, 2001 (non Sagenograptus Obut \& Sobolevskaya, 1962: see Anisograptidae), Semiplectograptus Kozłowska-Dawidziuk, 1995; Sokolovograptus Obut \& Zaslavskaya, 1976; Spinograptus Bouček \& Münch, 1952; Valentinagraptus Piras, 2006.

Discussion. - Bouček \& Münch (1952) separated the Plectograptinae mainly through their biostratigraphical appearance (see Bouček \& Münch 1952, diagram on p. 8), recognizing an interval without the occurrence of retiolitids in the Monograptus firmus/Monograptus riccartonensis biozones. They also recognized a few novel characters like the lack of the reticulum in most Plectograptinae and the small size of most colonies among others, but the authors did not use isolated material to work on that later workers used for their analyses (e.g. Lenz \& Melchin 1997, Bates et al. 2005, Kozłowska-Dawidziuk et al. 2003). Plectograptinae has more recently been based on the presence of pustulose bandages with smooth to striated bandages present in Retiolitinae (Lenz \& Melchin 1997). However, Lenz \& Melchin (1997) included Rotaretiolites with striated bandages in the Plectograptinae. The consensus tree in Bates et al. (2005, fig. 8) showed Rotaretiolites in a basal position, while the McClade default tree indicated a more derived position for the taxon. The ambiguity of the position of Rotaretiolites with its characteristic striated bandages in the analysis may indicate incomplete knowledge of retiolitid faunas from the mid-Telychian time interval. The strict separation of the Retiolitinae and Plectograptinae in Lenz \& Melchin (1987) may be an artefact of the poor fossil record and intermediate taxa may show a more complex picture when found.
Superfamily Monograptoidea Lapworth, 1880e (p. 191) (ex Monograpta (Monoprionida) Lapworth, 1880e, p. 191)

Definition. - (Melchin et al. 2011, p. 294) The most recent common ancestor of Avitograptus avitus and Monograptus priodon and all of its descendants (Node 1, Figs 2, 3 [in Melchin et al. 2011]).

Discussion. - Graptoloids with a pattern J or pattern M astogeny and a biserial, uni-biserial or uniserial colony are included in the taxon. Cladial branching is present in some derived taxa and may appear independently in a number of groups. The thecal style is highly variable and needs a detailed analysis.

Lapworth (1880e) included only the family Monograptidae with the three genera Rastrites, Cyrtograptus and Monograptus in the Monograpta or Monoprionida. The dimophograptids (genus Dimorphograptus) he included as a subgenus in the genus Diplograptus. Melchin et al. (2011) emended Monograptoidea and included Dimorphograptidae as a stem group. The defining synapomorphies include the pattern $\mathbf{J}$ astogeny with a slender, elongate, U-shaped proximal thecal pair and an abrupt lateral differentiation of th $1^{2}$ from the upward growing portion of th $1^{1}$ (Melchin et al. 2011, pp. 294-295).

Mitchell (1987) suggested including Glyptograptinae, Dimorphograptinae and Retiolitinae as subfamilies in Monograptidae, expanding the concept of the Monograptidae considerably. This concept is essentially the concept of the Neograptina as proposed by Štorch et al. (2011) and was difficult to accept for most specialists, even though from a cladistic point of view it made sense showing the large-scale phylogenetic relationships.

Family Dimorphograptidae Elles \& Wood, 1908 (p. 347) (= Heteroprionidae Tullberg, 1883, p. 14)

(incl. Akidograptinae Li \& Ge 1981, p. 227)

Definition. - (Melchin et al. 2011, p. 295) The partial clade that includes the common ancestor of Avitograptus avitus and Monograptus priodon and all of its descendents, including Dimorphograptus elongatus, but excluding those taxa included in the Family Monograptidae (i.e. excluding the uniserial monograptids).

Genera included. - Akidograptus Davies, 1929; Avitograptus Melchin et al., 2011; Bulmanograptus Přibyl, 1948b; Cardograptus Hundt, 1965; Dimorphograptus Lapworth, 1876b; Metadimorphograptus Přibyl, 1948b; Parakidograptus Li \& Ge, 1981.

Discussion. - Dimorphograptidae includes graptolites with a pattern $\mathrm{J}$ astogeny, which may be uni-biserial or fully bi- 
serial. The sicula is relatively long (usually $1.7-2.0 \mathrm{~mm}$ ) and is fully exposed on its dorsal side. The downward growing portion of th $1^{1}$ is strongly reduced and does not reach down to sicular aperture, leaving a portion of sicula exposed for its full circumfence. Obverse and reverse walls of th $1^{1}$ both grow straight upward for all or much of their length. The rhabdosome is fully or partly septate. The thecae are commonly orthograptid to climacograptid but may be partly isolate or slightly hooked, especially in uniserial portions (Melchin 1989, p. 301).

Elles \& Wood (1908) erected Dimorphograptidae for the single genus Dimorphograptus as a substitute for the family Heteroprionidae Tullberg (1883) in order to "bring it into harmony with the names of the other families of the Graptoloidea" (Elles \& Wood 1908, p. 348). A number of genera was subsequently referred to the family and its content redefined by Melchin (1998) and especially by Melchin et al. (2011) as a paraphyletic taxon. The differentiation of Akidograptidae and Dimorphograptidae by Koren' \& Rickards (1996) is not followed here, as most taxa are known only from flattened shale material and constructional details are not available for a precise differentiation.

Family Monograptidae Lapworth, 1873b

(table facing p. 555) (emend. Melchin et al. 2011, p. 295)

(= Monoprionidae Tullberg, 1883, p. 14

[misspelt Mono-Diprionidae in Latin version, p. 12])

(non Monograptidae of Mitchell 1987

[= Neograptina: Melchin et al. 2011])

Definition. - (Melchin et al. 2011, p. 295) The first species within the clade that contains Monograptus priodon to develop a scandent, uniserial rhabdosome and all its descendants (Node 2, figs 2, 3 in Melchin et al. 2011).

Genera included. - Abiesgraptus Hundt, 1935; Acanthograptus Tsegelniuk, 1976; Alexandrograptus Přibyl, 1981; Atavograptus Rickards, 1974; Averianowograptus Obut, 1949; Awarograptus Zalasiewicz \& Howe, 2003; Barrandeograptus Bouček, 1933; Bohemograptus Přibyl, 1967a; Bugograptus Tsegelniuk, 1976; Campograptus Obut, 1949; Cochlograptus Obut, 1987; Colonograptus Přibyl, 1942; Coronograptus Obut \& Sobolevskaya, 1968 in Obut et al. (1968); Corymbites Obut \& Sobolevskaya, 1967 in Obut et al. (1967); Crinitograptus Rickards, 1995; Cucullograptus Urbanek, 1954; Cultellograptus Loydell \& Nestor, 2006; Cyrtograpsus Carruthers, 1867 in Murchison (1867); Damosiograptus Obut, 1950; Demirastrites Eisel, 1912; Dibranchiograptus Hundt, 1949; Didymograptoides Hundt, 1951; Diversograptus Manck, 1923; Dulebograptus Tsegelniuk, 1976; Egregiograptus Rickards \& Wright, 1997; Enigmagraptus Rickards \& Wright, 2004; Euroclimacis Štorch, 1998a; Falcatograptus Hundt, 1965; Formo- sograptus Bouček et al., 1976; Fterograptus Tsegelniuk, 1976; Gangliograptus Hundt, 1939; Globosograptus Bouček \& Přibyl, 1948 in Přibyl (1948a); Heisograptus Tsegelniuk, 1976; Hemimonograptus Zhao 1984; Hubeigraptus Li, 1995; Huttagraptus Koren’ \& Bjerreskov, 1997; Istrograptus Tsegelniuk, 1976; Korenea Rickards et al., 1995; Kurganakograptus Golikov, 1969; Lagarograptus Obut \& Sobolevskaya, 1968 in Obut et al. (1968); Lapworthograptus Bouček \& Přibyl, 1952; Lenzia Rickards \& Wright, 1999; Linograptus Frech, 1897; Lituigraptus Ni, 1978; Lobograptus Urbanek, 1958; Lomatoceras Bronn, 1835; Mediograptus Bouček \& Přibyl, 1948 in Přibyl (1948a); Metamonograptus Wang, 1977; Monoclimacis Frech, 1897; Monograpsus Geinitz, 1852; Monoprion Barrande, 1850; Mystiograptus Hundt, 1965; Neocolonograptus Urbanek, 1997; Neocucullograptus Urbanek, 1970; Neodiversograptus Urbanek, 1963; Neolagarograptus Štorch, 1998b; Neolobograptus Urbanek, 1970; Neomonograptus $\mathrm{Mu} \& \mathrm{Ni}$, 1973; Obutograptus Mu, 1955; Oktavites Levina, 1928; Paradiversograptus Sennikov, 1976; Paragraptus Hundt, 1965; Paramonoclimacis Wang \& Ma, 1977 in Wang \& Jin (1977); Pernerograptus Přibyl, 1941; Polonograptus Tsegelniuk, 1976; Pomatograptus Jaekel, 1889; Přibylograptus Obut \& Sobolevskaya, 1966 (Fig. 25B); Pristiograptus Jaekel, 1889; Prochnygraptus Přibyl \& Štorch, 1985; Procyrtograptus Poulsen, 1943; Prolinograptus Rickards \& Wright, 1997; Proteograptus Lenz et al., 2012; Pseudomonoclimacis Mikhailova, 1975; Pseudostreptograptus Loydell, 1991a; Quasipernerograptus Zhao, 1984; Rastrites Barrande, 1850 (Fig. 25A); Rastrograptus Hopkinson \& Lapworth, 1875; Saetograptus Přibyl, 1942; Sinodiversograptus Mu \& Chen, 1962; Skalograptus Tsegelniuk, 1976; Slovinograptus Urbanek, 1997; Spirograptus Gürich, 1908 (Fig. 25C), Stavrites Obut \& Sobolevskaya, 1968 in Obut et al. (1968); Stimulograptus Přibyl \& Štorch, 1983; Streptograptus Yin, 1937 (Fig. 25E-G), Tamplograptus Tsegelniuk, 1976; Testograptus Přibyl, 1967b; Thuringiograptus Hundt, 1935; Tirassograptus Tsegelniuk, 1976; Torquigraptus Loydell, 1993; Trimorphograptus Zhao, 1984; Tyrsograptus Obut, 1949; Uncinatograptus Tsegelniuk, 1976; Uralograptus Koren', 1962; Urbanekia Rickards \& Wright, 1999; ?Vietnamograptus van Phuc, 1998; Wandograptus Rickards \& Jell, 2002; Wolynograptus Tsegelniuk, 1976.

Discussion. - The Monograptidae includes single-stiped axonophorans with the stipe growing in opposite direction of the sicular aperture (Fig. 25A, C-E) and along the nema. The rhabdosome shapes and thecal styles are highly variable and the secondary development of multiramous colonies through cladial branching is common.

Melchin et al. (2011) redefined Monograptidae as a monophyletic taxon, stating the defining synapomorphies to be the loss of the dicalycal theca and the loss of the initial downward growth of the first theca. The content of the 

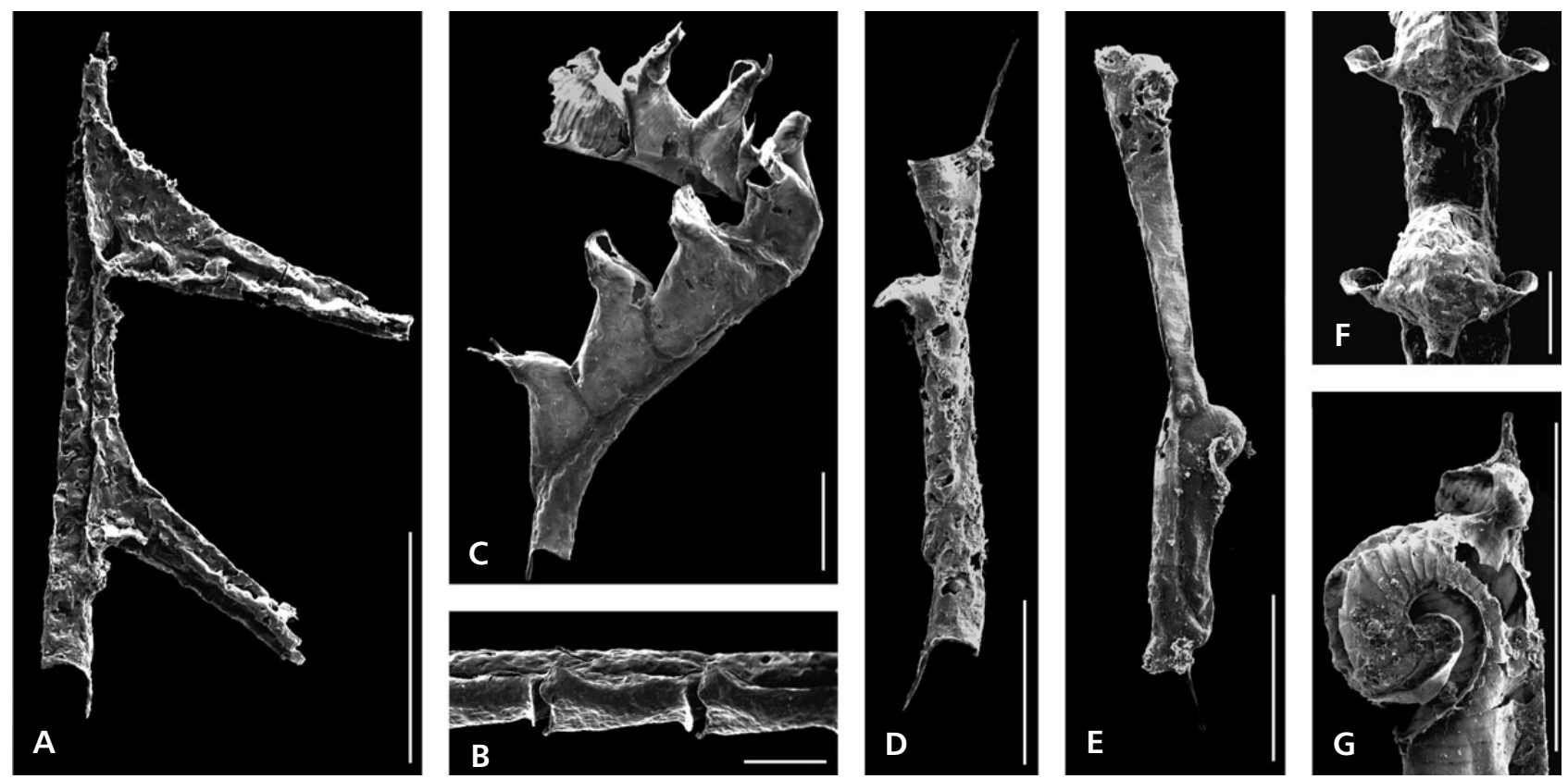

Figure 25. Examples of Monograptidae, based on isolated material, showing siculae and complex thecal development. • A - Rastrites sp., JM14-3a, thecal apertures missing. • B - Pribylograptus argutus (Lapworth), NMW 2002/19G.29A, stipe fragment. • C - Spirograptus turriculatus (Barrande), SOL 1-97-1-4a, small specimen with proximal end showing curved sicula. • D - Monograptus sp., JM07-2a. • E, G - Streptograptus sartorius (Törnquist), small sicula with two thecae and an isolated metatheca with cupulae at the growing end, NMW 2002/19G.13C, NMW 2002/19G.15C. - F - Streptograptus dalecarlicus Loydell \& Maletz, NMW 2002/19G.8E, fragment, showing thecae in ventral view. Scale bar represents 1 mm.

family was not changed from the original intent of Lapworth (1873b), however. Monograptidae includes at least 95 genera, of which a considerable number may represent synonyms of other taxa. This is the highest number of genera in any graptolite family.

The pattern M astogeny (Fig. 18) is generally considered the development in all monograptids (Mitchell 1987, Melchin 1998), but considerable variation was found more recently in the development of the porus type and a number of slightly divergent development types have been noted (e.g. Lukasik \& Melchin 1994, 1997; Dawson \& Melchin 2007).

A number of subfamilies have been described subsequently [e.g. Cucullograptinae Urbanek, 1958; Linograptinae Obut, 1957; Monograptinae Lapworth (Urbanek 1958, p. 43); Neocucullograptinae Urbanek, 1970; Pristiograptini Gürich, 1908; Saetograptinae Urbanek, 1958], but these are not discussed by Bulman $(1955,1970)$ or Melchin et al. (2011). A modern assessment of the included genera does not exist.

A number of phylogenetic analyses has been proposed recently for the genus Pristiograptus and its descendants, showing the genus to be extremely long-ranging and producing a number of "off-shoots" that radiated into new monograptid taxa (Radzevičius 2007, Urbanek et al. 2012), but a cladistic analysis for the whole group does not exist and the monograptids, despite their important use in biostratigraphy, are one of the least known graptolite taxa when it comes to their phylogeny. Except for detailed studies of smaller groups within the Monograptidae, Rickards et al. (1977) provided the last comprehensive overview of evolutionary relationships among the monograptids.

Genera of uncertain relationships and non-graptolitic taxa

Many genera have been assigned to the graptolites, the relationships of which are uncertain or doubtful. Some of these have been referred to a number of non-graptolitic fossil groups (e.g. Megalograptus to the eurypterids), but others clearly belong to the Graptolithina. All of these genera are listed here for convenience. Most of the taxa have not been revised in recent years and often further information is not available. Bulman $(1955,1970)$ listed several "unrecognizable genera" in the two available editions of the Treatise.

Algae. - Boučekocaulis Obut, 1960; Calyptograpsus Spencer, 1878; Crinocaulis Obut, 1960; Diplospirograptus Ruedemann, 1925; Estoniocaulis Obut \& Rytsk, 1958; Inocaulis Hall, 1852, Leveillites Foerste, 1923; Medusaegraptus Ruedemann, 1925; Palmatophycus Bouček, 1941; Rhadinograptus Obut, 1960; Thallograptus Ruedemann, 1925.

Discussion. - LoDuca (1990), Mierzejewski (1991) and Tinn et al. (2009) are among the authors who have 
re-identified a number of supposed graptolites as noncalcified dasycladacean and thallophytic algae. The genera $\mathrm{Me}$ dusaegraptus, Diplospirograptus, Palmatophycus and Leveillites can safely be referred to various groups of algae. Many additional taxa have not yet been investigated, but may also turn out to represent algae and, thus, are listed here.

Phyllocarids. - Coronagraptus Hundt, 1951; Dawsonia Nicholson, 1873 [non Dawsonia Hartt in Dawson, 1868: Trilobita, Eodiscidae]

Discussion. - The genus Coronagraptus may be identified as the phyllocarid Peltocaris Salter, 1862. The only available specimen from the Silurian of Thuringia (Hundt 1951a, fig. 16) clearly shows a bivalved imprint in black shale. Gürich (1928) recognized the similarity of Dawsonia to Peltocaris. Page et al. (2009) discussed the problematical origin and interpretation of the genus Dawsonia. The authors recognized a part of the material described initially by Nicholson (1873) as Dawsonia and interpreted by him as "ovarian vesicles" of graptolites as tail-pieces of phyllocarids and phosphatic brachiopods, but included also some unidentified fossil remains.

Trace fossils. - Nereograpsus Geinitz, 1852; Protovirgularia M'Coy, 1850; Triplograptus Richter, 1871; Triplograptus Hundt, 1965.

Discussion. - A number of trace fossils have been identified as graptolites in earlier publications, as the concept of the "graptolites" was still emerging and details were unexplored. Even the trace fossil Oldhamia has been identified as a graptolite in the past (see Grant 1893). Thus, it is no surprise that M'Coy (1850) and Geinitz (1852) among others referred fossils now recognized as trace fossils to the graptolites. The genus Protovirgularia is now considered to be the trace of a bivalve (Seilacher \& Seilacher 1994) for example. In the case of Nereograpsus, Geinitz (1866) himself corrected his earlier (Geinitz 1852) opinion.

Hydroids. - Archaeodendrum Obut, 1974; Chaunograptus Hall, 1879; Dyadodendrum Sennikov, 1998; Plumalina Hall, 1858; Protohalecium Chapman \& Thomas, 1936.

Discussion. - Especially Mierzejewski (1986a) discussed a number of taxa initially referred to the graptolites as hydroids and scyphozoans. The author discussed the Chaunograptidae Bulman, 1955 (Mierzejewski 1986a, p. 162) in some details and referred them to the hydroid suborder Thecaphora. The author also included the Inocaulidae as a family in the Hydroidea and treated the Cambrian Dithecoidea as possible colonial scyphozoans. Some of the latter taxa are, however, now recognized as genuine graptolites through the recognition of fusellar structures (Maletz et al. 2005).
Uncertain taxa. - Acanthastus Kozłowski, 1949; Ascograptus Ruedemann, 1925; Birastrites Geinitz, 1866; Buthograptus Hall, 1861; Cameragraptus Hundt, 1953b; Coelograptus Ruedemann, 1947; Conograptus Ruedemann, 1947; Cystoturriculagraptus Hundt, 1953a; Demicystifer Hundt, 1959; Discophyllum Hall, 1847; Furkagraptus Hundt, 1959; Geminograptus Hundt, 1951; Halograptus Hundt, 1936a; Humiligraptus Hundt, 1940; Hunanodendrum Mu et al., 1974; Labrumograptus Hundt, 1953a; Nereitograptus Hundt, 1951; Nodosugraptus or Nodosograptus Hundt, 1951; Parademicystograptus Hundt, 1950; Paradimorphograptus Hundt, 1951; Phycograptus Gurley, 1896; Planktograptus Yakovlev, 1933; Pleurograptoides Averianow, 1931; Polygonograptus Bouček, 1957; Protabrograptus Ni, 1981; Protistograptus McLearn, 1915; Protograptus Matthew, 1886; Ramulograptus Ross \& Berry, 1963; Sinograptus Shrubsole, 1880 (cited in Münch 1931, p. 42); Spinosudiplograptus Hundt, 1951; Stelechograptus Ruedemann, 1947; Stolonofolliculus Zessin \& Puttkamer, 1994; Strophograptus Ruedemann, 1947; Thecocystograptus Hundt, 1950; Undagraptus Hemmann, 1951; Undograptus Hundt, 1949 in Nindel (1949).

Discussion. - The genera listed here have been included in the list for various reasons. They were originally described as graptolitic, but are either too poorly preserved for a positive identification or are clearly not graptolitic. In a number of taxa, the identification may be established in the future, but for others it may never be possible to recognize their identity. The type material for Humiligraptus, for example, has never been identified in a collection and judging from the photos, the specimens are not to be attributed to the graptolites, but may represent trace fossils or inorganic markings on the rock surfaces. A number of taxa named by Hundt in various publications have generally been considered unrecognizable (see Bulman 1970), but these are not the only described genera, that are only questionably referred to the graptolites. Specimens identified under the name Cameragraptus can be identified as biserial graptolites in scalarifrom view only. Others are too poorly characterized and the type material is very incomplete. Thus, an unambiguous identification is impossible. A re-investigation of the types of the genus Protabrograptus, for example, did not provide convincing evidence of a graptolitic nature of the material. A careful re-examination of the material referred to the above listed genera may be necessary to establish their taxonomic relationships.

Names not used any more. - Graptolithus Linnæus, 1758 [suppressed ICZN 1954a]; Lomatoceras [suppressed ICZN 1954b]; Monoprion [suppressed ICZN 1954b]; Prionotus Hisinger, 1837 [syn. of Graptolithus; homonym of Prionotus Lacépède, 1801: Actinopterygii, family Triglidae]. 


\section{Acknowledgements}

Many people helped with literature and provided suggestions on how to deal with graptolite taxonomy. Dan Goldman, Chuck Mitchell and Mike Melchin provided information and feedback on cladistics and other aspects of graptolite taxonomy, even though their ideas may not be in agreement with the here expressed opinions on graptolite taxonomy that rests completely on my understanding and imagination. Special thanks are to Michael Steiner and Bernd Weber (FU Berlin, Germany) for listening to my constant flow of words of frustration in the last few months and their insight into graptolite taxonomy from a "very German approach". David Loydell, Michael Melchin and Yuandong Zhang provided extensive and very useful reviews.

\section{References}

Allman, G.J. 1872. On the morphology and affinities of graptolites. Annals and Magazine of Natural History, Fourth Series 9, 364-380.

Andersson, K.A. 1907. Die Pterobranchier der schwedischen Südpolar-Expedition 1901-1903 nebst Bemerkungen über Rhabdopleura normani Allman. Wissenschaftliche Ergebnisse der Schwedischen Südpolar-Expedition 1901-1903, Volume 5, 1-122.

ANDRES, D. 1977. Graptolithen aus ordovizischen Geschieben und die frühe Stammesgeschichte der Graptolithen. Paläontologische Zeitschrift 51, 52-93.

DOI 10.1007/BF02986602

ANDRES, D. 1980. Feinstrukturen und Verwandtschaftsbeziehungen der Graptolithen. Paläontologische Zeitschrift 54, 129-170. DOI 10.1007/BF02985886

Angelin, N.P. 1854. Palceontologia Scandinavica. Part 1, Crustacea formationis transitionis. 93 pp. T.O. Weigel, Lipsiae [originally issued in 2 parts 1851, 1854; also Holmiae, Stockholm 1878, P.A. Norstedt \& Söner; ed. G. Lindström].

Averianow, B. 1931. Graptoloidea from the shales of the UraTuibe region and the Zeravshan Valley, Turkestan. Transactions of the Geological and Prospecting Service of the USSR $101,1-29$.

Barrande, J. 1850. Graptolites de Bohême. 74 pp. Théophile Haase Fils, Prague. [published by the author]

BARRoIs, C. 1893. Sur le Rouvilligraptus richardsoni de Cabrières. Annales de la Société géologique du Nord 21, 107-112.

BAtEs, D.E.B. \& KIRK, N.H. 1992. The ultrastructure, mode of construction and functioning of a number of Llandovery ancorate diplograptid and retiolitid graptolites. Modern Geology $17(1-3), 1-270$.

Bates, D.E.B. \& Urbanek, A. 2002. The ultrastructure, development, and systematic position of the graptolite genus Mastigograptus. Acta Palaeontologica Polonica 47(3), 445-458.

Bates, D.E.B., KozŁowska, A. \& Lenz, A.C. 2005. Silurian retiolitid graptolites: Morphology and evolution. Acta Palaeontologica Polonica 50(4), 705-720.

BAtESON, W. 1885. The later stages in the development of Bala- noglossus kowalevskii, with a suggestion as to the affinities of the Enteropneusta. Quarterly Journal of Microscopical Science $25,81-122$.

BeAvis, F.C. 1972. The manubriate isograptids. Geological Magazine 109(3), 193-204. DOI 10.1017/S0016756800039236

Beckly, A. \& MaletZ, J. 1991. The Ordovician graptolites Azygograptus and Jishougraptus in Scandinavia and Britain. Palaeontology 34, 887-925.

BekLemishev, V.N. 1951a. On the systematic structure of Animals Vtorichnorotye (Deuterostomia), their origin and composition. Uspekhi sovremennoi biologii 32, 256-270.

BekLemishev, V.N. 1951b. [Russian editions in 1951, 1964] Osnovy sravnitelnoi anatomii bespozvonochnykh. 2 volumes, 430, 478 pp. Sovetskaya nauka, Moskva. [German edition: Grundlagen der vergleichenden Anatomie der Wirbellosen 1958 (Band 1. Promorphologie); 1960 (Band 2. Organologie). VEB Deutscher Verlag der Wissenschaften, Berlin.] [English edition: Beklemishev, V.N. 1970. Principles of Comparative Anatomy of Invertebrates. Vol. 1, 490 pp.; vol. 2, 529 pp.; Oliver and Boyd, Edinburgh.]

Bengtson, S. \& UrbaneK, A. 1986. Rhabdotubus, a Middle Cambrian rhabdopleurid hemichordate. Lethaia 19(4), 293-308. DOI 10.1111/j.1502-3931.1986.tb00743.x

Berlese, A. 1916. Centuria seconda di Acari nuovi. Redia 12, 125-177.

BouČEK, B. 1933. Monographie der obersilurischen Graptolithen aus der Familie Cyrtograptidae. Práce geologicko-paleontologického ústavu Karlovy university v Praze 1, 1-84.

BouČEK, B. 1941. Über neue Algenreste aus dem böhmischen Silur. Věstník Královské České společnosti nauk, 1-5.

BouČEK, B. 1956. Graptolitová a dendroidová fauna klabavských břidlic $(\mathrm{d} ß)$ z rokycanské Stráně. The graptolite and dendroid fauna of the Klabava Shales (dß) from the Strán at Rokycany. Sborník Ústředního ústavu geologickeho, Oddíl paleontologický 22, 123-164 [in Czech], 165-196 [in Russian], 197-227 [in English].

BouČEK, B. 1957. The dendroid graptolites of the Silurian of Bohemia. Rozpravy Ústředního ústavu geologického 23, 1-294.

BoučEK, B. 1973. Lower Ordovician graptolites of Bohemia. 185 pp. Publishing House of the Czechoslovak Academy of Sciences, Prague.

Bouček, B., Mihajlovic, M. \& Veselinovic, M. 1976. Graptolites of Upper Silurian and Lower Devonian of Zvonacka Banja (Eastern Yugoslavia). Glas de l'Academie serbe des sciences et des arts, Classe des sciences mathématiques et naturelles 39, 79-114.

BouČEK, B. \& Münch, A. 1944. Die Retioliten des mitteleuropäischen Llandovery und unteren Wenlock [Retioliti středoevropského Llandovery a spodního Wenlocku]. Bulletin international de l'Académie tchèque des Sciences 44, 527-579.

BouČEK, B. \& MÜNCH, A. 1952. Retioliti středoevropského svrchního wenlocku a ludlowu. [The central European Retiolites of the Upper Wenlock and Ludlow]. Sborník Ústředního ústavu geologického, Oddíl paleontologický 19, 1-151. [1-54, Czech text; 55-103, Russian text; 104-151 English text]

BouČEK, B. \& PřIBYL, A. 1951. Taxonomy and phylogeny of 
some Ordovician graptolites. Bulletin international de l'Académie tchèque des Sciences 52(20), 1-17.

BouČEK, B. \& Přı̇YL, A. 1952. Contribution to our knowledge of the Cyrtograptids from the Silurian of Bohemia and on their stratigraphical importance. Rozpravy České akademie věd, Řada matematicko-přirodovědných věd 62(9), 1-24.

BRonN, H.G. 1835. Lethaea Geognostica, Erster Band, das Übergangs-, bis Oolithen-Gebirge enthaltend. $768 \mathrm{pp}$. Schweizerbart, Stuttgart.

BronN, H.G. 1849. Handbuch der Geschichte der Natur. Dritter Band, Zweite Abtheilung. II. Theil: Organisches Leben (Schluß). Index palaeontologicus oder Ueberblick der bis jetz $t$ bekannten fossilen Organismen. 1106 pp. Schweizerbart, Stuttgart.

Bourlat, S.J., Juliusdottir, T., Lowe, C.J., Freeman, R., Aronowicz, J., Kirschner, M., Lander, E.S., Thorndyke, M., NaKano, H., Kohn, A.B., Heyland, A., Moroz, L.L., Copley, R.R. \& TELFORD, M.J. 2006. Deuterostome phylogeny reveals monophyletic chordates and the new phylum Xenoturbellida. Nature 444, 85-88. DOI 10.1038/nature05241

BrummitT, R.K. 1996. In defense of paraphyletic taxa, 371-384. In VAN der Maesen, L.J.G., VAn der Burgt, X.M. \& VAN Medenbach van Rooy, J.M. (eds) The Biodiversity of African Plants. Proceedings, XIV th AETFAT Congress, 22-27, August 1994, Wageningen. Kluwer Academic Publishers, Dordrecht.

BrummitT, R.K. 2003. Further dodged defense of paraphyletic taxa. Taxon 52, 803-804. DOI 10.2307/3647353

BrummitT, R.K. \& SoseF, M.S.M. 1998. Paraphyletic taxa are inherent in Linnaean classification - a reply to Freudenstein. Taxon 47, 411-412. DOI 10.2307/1223771

Bulman, O.M.B. 1927a. A monograph of British dendroid graptolites. Palaeontographical Society, London Monograph 79 (367), 1-28.

Bulman, O.M.B. 1927b. Koremagraptus, a new dendroid graptolite. Annals and Magazine of Natural History, Series 9(19), 344-347.

Bulman, O.M.B. 1929. The genotypes of graptolites. Annals and Magazine of Natural History 4(20), 169-185. DOI 10.1080/00222932908673039

Bulman, O.M.B. 1933. On the graptolites prepared by Holm. VI. Structural characters of some Dictyonema and Desmograptus species from the Ordovician and Silurian rocks of Sweden and the east Baltic Region. Arkiv för Zoologi 26A(5), 1-52. [plates separate, large size]

Bulman, O.M.B. 1934. A monograph of British dendroid graptolites, Part III. Palaeontographical Society Monograph 86(392), xxxiii-1x, 65-92.

Bulman, O.M.B. 1936. Rhaphidograptus, a new graptolite genus. Geological Magazine 73(1), 19-26. DOI 10.1017/S001675680008732X

Bulman, O.M.B. 1938. Graptolithina, 1-92. In Schindewolf, O.H. (ed.) Handbuch der Paläozoologie, vol. 2D. Borntraeger, Berlin.

Bulman, O.M.B. 1941. Some dichograptids of the Tremadocian and Lower Ordovician. Annals and Magazine of Natural History, Series 2(7), 100-121.

Bulman, O.M.B. 1942. The structure of the dendroid graptolites.
Geological Magazine 79(5), 284-290.

DOI 10.1017/S0016756800076007

Bulman, O.M.B. 1945. A monograph of the Caradoc (Balclatchie) graptolites from limestones in Laggan Burn, Ayrshire, Part 1. Palaeontographical Society Monograph 98(430), 1-42.

Bulman, O.M.B. 1950. Graptolites from the Dictyonema Shales of Quebec. Quarterly Journal of the Geological Society of London 106, 63-99.

DOI 10.1144/GSL.JGS.1950.106.01-04.05

Bulman, O.M.B. 1953. Some graptolites from the Ogygiocaris Series (4a ) of the Oslo district. Arkiv för Mineralogi och Geologi 1(17), 509-518.

Bulman, O.M.B. 1955. Graptolithina, xvii + 101 pp. In Moore, R.C. (ed.) Treatise on Invertebrate Paleontology, Part V. Geological Society of America \& University of Kansas Press, Lawrence.

Bulman, O.M.B. 1970. Graptolithina, xxxii + 163 pp. In TeICHERT, C. (ed.) Treatise on Invertebrate Paleontology, Part V, second edition. Geological Society of America and University of Kansas Press, Lawrence.

Bulman, O.M.B. \& Rickards, R.B. 1968. Some new diplograptids from the Llandovery of Britain and Scandinavia. Palaeontology 11(1), 1-15.

Cameron, C.B., Swalla, B.J. \& Garey, J.R. 2000. Evolution of the chordate body plan: New insights from phylogenetic analysis of deuterostome phyla. Proceedings of the National Academy of Sciences (USA) 97(9), 4469-4474.

DOI 10.1073/pnas.97.9.4469

Cantino, P.D. \& De QueIroz, K. 2010. International Code of Phylogentic Nomenclature Version 4c (PhyloCode). http://www.ohiou.edu/phylocode/index.html

Cannon, J.T., Rychel, A.L., Eccleston, H., Halanych, K.M. \& Swalla, B.J. 2009. Molecular phylogeny of Hemichordata, with updated status of deep-sea enteropneusts. Molecular Phylogenetics and Evolution 52, 17-24.

DOI 10.1016/j.ympev.2009.03.027

CARLuCCI, J. 2008. Phylogenetic analysis, systematics, and evolution of early Ordovician graptolites. 128 pp. MSc. thesis, SUNY Buffalo.

Carruthers, W. 1858. Dumfriesshire graptolites with description of three new species. Proceedings of the Royal Society of Edinburgh 1, 466-470.

CAster, K.E. \& KJellesvig-Waering, E.N. 1955. Family Megalograptidae Caster, K.E. \& Kjellesvig-Waering, E.N. 1955, p. P36. In Moore, R.C. (ed.) Treatise on Invertebrate Paleontology, Part P, Arthropoda 2. Geological Society of America \& University of Kansas Press, Lawrence.

CAster, K.E. \& KJellesvig-Waering, E.N. 1964. Upper Ordovician eurypterids of Ohio. Palaeontographica Americana 4, 301-358.

Chapman, A.J., Rickards, R.B. \& Grayson, R.F. 1993. The Carboniferous dendroid graptolites of Britain and Ireland. Proceedings of the Yorkshire Geological Society 49(4), 295-319. DOI 10.1144/pygs.49.4.295

Chapman, F. 1917. Report on Cambrian fossils from Knowley East, near Heathcote. Geological Survey of Victoria, Records 4(1), 87-102. 
Chapman, F. 1919. On some hydroid remains of Lower Palaeozoic age from Monegetta, near Lancefield. Proceedings of the Royal Society of Victoria, New Series 31(2), 388-393.

Chapman, F. \& Thomas, D.E. 1936. The Cambrian Hydroidea of the Heathcote and Monegeeta Districts. Proceedings of the Royal Society of Victoria, New Series 48(2), 193-212.

Chen, X., Sun, X.R. \& Han, N.R. 1964. Yushanograptus, a new graptolite genus from the Ningkuo Shale (Lower Ordovician) of Yushan, north-eastern Jiangxi (Kiangsi). Acta Palaeontologica Sinica 12(2), 236-240.

Chen, X. \& Zhang, Y.D. 1996. Isograptids of China, 82-89. In WANG, H.Z. \& WANG, X.L. (eds) Centennial memorial volume of Prof. Sun Yunzhu (Y.C. Sun): palaeontology and stratigraphy. China University of Geosciences Press, Beijing.

Chо, H.S., Kiм, J.Y. \& Jin, Y.P. 2009. Phylogenetic relationships among Adelograptus, Ancoragraptus and Psigraptus. Geosciences Journal 13(2), 133-139.

DOI 10.1007/s12303-009-0012-6

Chu, M.T. 1965. New materials of Sinograptidae. Acta Palaeontologica Sinica 13(1), 94-106.

Clark, T.H. 1924. The paleontology of the Beekmantown Series at Levis, Quebec. Bulletin of American Paleontology 10(41), $1-151$.

CONE, M.R. 2004. A cladistic and biostratigraphic analysis of Upper Ordovician climacograptid graptolites (Family Diplograptidae). 107 pp. Unpublished MS thesis, University at Buffalo, SUNY.

CoOper, R.A. 1973. Taxonomy and evolution of the genus Isograptus Moberg in Australasia. Palaeontology 16(1), 45-115.

CoOPER, R.A. \& Fortey, R.A. 1982. The Ordovician graptolites of Spitsbergen. Bulletin of the British Museum (Natural History), Geology Series 36(3), 157-302.

CoOper, R.A. \& LindHolm, K. 1985. The phylogenetic relationships of the graptolites Tetragraptus phyllograptoides and Pseudophyllograptus cor. Geologiska Föreningens i Stockholm Förhandlingar 106(3), 279-291. DOI 10.1080/11035898509454648

Cooper, R.A., Maletz, J., Wang, H.F. \& Erdtmann, B.-D. 1998. Taxonomy and evolution of earliest Ordovician graptoloids. Norsk Geologisk Tidsskrift 78(1), 3-32.

Cooper, R.A. \& McLaurin, A.N. 1974. Apiograptus gen. nov. and the origin of the biserial graptoloid rhabdosome. Special Papers in Palaeontology 13, 75-85.

CoOPER, R.A. \& NI, Y.N. 1986. Taxonomy, phylogeny and variability of Pseudisograptus Beavis. Palaeontology 29, 313-363.

CROwTHER, P.R. 1981. The fine structure of graptolite periderm. Special Papers in Palaeontology 26, 1-119.

Crowther, P. \& Rickards, B. 1977. Cortical bandages and the graptolite zooid. Geologica et Palaeontologica 11, 9-46.

Cuerda, A.J., Rickards, R.B. \& Cingolani, C. 1988. A new Ordovician-Silurian boundary section in San Juan Province, Argentina, and its definitive graptolite fauna. Journal of the Geological Society of London 145(5), 749-757.

DOI 10.1144/gsjgs.145.5.0749

DAvies, K.A. 1929. Notes on the graptolite faunas of the Upper
Ordovician and Lower Silurian. Geological Magazine 66, 1-27. DOI 10.1017/S0016756800099763

Dawson, D.H. \& Melchin, M.J. 2007. A possible transitional stage between the resporption porus and the primary porus in early monograptid graptolites. Acta Palaeontologica Sinica 46 (Suppl.), 89-94.

Dawson, J.W. 1868. Acadian Geology. The Geological Structure, Organic Remains, and Mineral Resources of Nova Scotia, New Brunswick, and Prince Edward Island. Second edition. 769 pp. Macmillan and Co., London.

DOI 10.5962/bhl.title.38560

De QueIroz, K. 2006. The PhyloCode and the distinction between taxonomy and nomenclature. Systematic Biology 55(1), 160-162. DOI 10.1080/10635150500431221

De QueIRoz, K. 2007. Toward an integrated system of clade names. Systematic Biology 56(6), 956-974. DOI 10.1080/10635150701656378

De Queiroz, K. \& Gauthier, J. 1990. Phylogeny as a central principle in taxonomy: phylogenetic definitions of taxonomic names. Systematic Zoology 39(4), 307-322.

DOI 10.2307/2992353

DeCKeR, C.E. 1945. The Wilberns Upper Cambrian graptolites from Mason, Texas. The University of Texas Publication 4401, 13-61.

DobrowolsKa, K. 2013. Reconstruction of the proximal ends of retiolitid rhabdosomes (Graptolithina) from the Upper Wenlock and the Lower Ludlow. Paläontologische Zeitschrift 87, 1-17. DOI 10.1007/s12542-012-0150-4

Durman, P. \& Sennikov, N.V. 1993. A new rhabdopleurid hemichordate from the Middle Cambrian of Siberia. Palaeontology 36(2), 283-296.

Ebach, M.C., Williams, D.M. \& Morrone, J.J. 2006. Paraphyly is bad taxonomy. Taxon 55, 1039-1040. DOI $10.2307 / 25065678$

EgEnhoff, S. \& Maletz, J. 2007. Graptolites as indicators of maximum flooding surfaces in monotonous deep-water shelf successions. Palaios 22, 374-384. DOI 10.2110/palo.2005.p05-096r

EichWALD, E.J. 1855. Beitrag zur geographischen Verbreitung der fossilen Thiere Russlands. Alte Periode. Bulletin de la Société impériale des naturalistes de Moscou 28(4), 433-466.

EISEL, R. 1912. Über zonenweise Entwicklung der Rastriten und Demirastriten. 53./54. Jahresbericht der Gesellschaft von Freunden der Naturwissenschaften Gera, 27-43. [different pagination in reprint, 1-17]

EISENACK, A. 1932. Neue Mikrofossilien des baltischen Silurs. II. (Foraminiferen, Hydrozoen, Chitinozoen u. a.). Paläontologische Zeitschrift 14, 257-277. DOI 10.1007/BF03042096

EISENACK, A. 1934. Neue Mikrofossilien des baltischen Silurs, III und Neue Mikrofossilien des böhmischen Silurs, I. Paläontologische Zeitschrift 16, 52-76. DOI 10.1007/BF03041667

EISENACK, A. 1935. Neue Graptolithen aus Geschieben baltischen Silurs. Paläontologische Zeitschrift 17, 73-90.

DOI 10.1007/BF03041692

Eisenack, A. 1937. Neue Mikrofossilien des baltischen Silurs. 4. Paläontologische Zeitschrift 19, 217-243.

DOI 10.1007/BF03042242 
Eisenack, A. 1941. Epigraptus bidens n. g. n. sp., eine neue Graptolithenart des baltischen Ordoviziums. Zeitschrift für Geschiebeforschung und Flachlandsgeologie 17(1), 24-28.

EISENACK, A. 1951. Retioliten aus dem Graptolithengestein. Palaeontographica A 100(5-6), 129-163.

EIsenack, A. 1974. Einige neue Graptolithen aus dem Ordovizium des Baltikums, ferner über Epigraptus und andere Idiotubidae. [Some new graptolites from the Baltic Ordovician and about Epigraptus and other Idiotubidae]. Neues Jahrbuch für Geologie und Paläontologie, Monatshefte 1974(11), 664-674.

EISENACK, A. 1982. Einige problematische Mikrofossilien [Some problematic microfossils]. Neues Jahrbuch für Geologie und Paläontologie, Monatshefte 1982, 629-636.

Elles, G.L. \& Wood, E.M.R. 1902. A monograph of British Graptolites. Part II - Dichograptidae. Palaeontographical Society Monograph 56(265), i-xxviii, 55-102.

Elles, G.L. \& Wood, E.M.R. 1907. A monograph of British Graptolites. Part 6. Palaeontographical Society Monograph 61(297), xcvii-cxx, 217-272.

Elles, G.L. \& Wood, E.M.R. 1908. A monograph of British Graptolites. Part 7, Palaeontographical Society Monograph 62(305), cxxxi-cxlviii, 273-358.

EMmons, E. 1855. American Geology, containing a statement of the Principles of the Science, with full illustrations of the characteristic American fossils also an atlas and a geological map of the United States. Part II. 251 pp. J. Munsell, 1875, Albany.

ERdTMAnN, B.-D. 1967. A new fauna of early Ordovician graptolites from St. Michel, Quebec. Canadian Journal of Earth Sciences 4(3), 335-355. DOI 10.1139/e67-017

ERdTMAnN, B.-D. 1988. The earliest Ordovician nematophorid graptolites: taxonomy and correlation. Geological Magazine 125(4), 327-348. DOI 10.1017/S0016756800013017

Erdtmann, B.-D., Maletz, J. \& Gutiérrez-Marco, J.C. 1987. The new early Ordovician (Hunneberg Stage) graptolite genus Paradelograptus (Kinnegraptidae), its phylogeny and biostratigraphy. Paläontologische Zeitschrift 61, 109-131. DOI 10.1007/BF02985945

Erdtmann, B.-D. \& VandenBerg, A.H.M. 1985. Araneograptus gen. nov. and its two species from the late Tremadocian (Lancefieldian, La2) of Victoria. Alcheringa 9(1-2), 49-63. DOI 10.1080/03115518508618958

FANG, Y., LiAnG, S., Zhang, D. \& Yu, J. 1990. Stratigraphy and graptolite fauna of Lishuwo Formation from Wuning, Jiangxi. 155 pp. Nanjing University Publishing House, Nanjing.

FARJON, A. 2007. In defense of a conifer taxonomy which recognizes evolution. Taxon 56(3), 639-641. DOI $10.2307 / 25065847$

FatKa, O., Kraft, P. \& Szabad, M. 2012. A first report of Sphenothallus Hall, 1847 in the Cambrian of Variscan Europe. Comptes Rendus Palevol 11, 539-547. DOI 10.1016/j.crpv.2012.03.003

FinNeY, S.C. 1978. The affinities of Isograptus, Glossograptus, Cryptograptus, Corynoides, and allied graptolites. Acta Palaeontologica Polonica 23(4), 481-495.

FinNeY, S.C. 1980. Thamnograptid, dichograptid and abrograptid graptolites from the Middle Ordovician Athens Shale of Alabama. Journal of Paleontology 54(6), 1184-1208.

FINNEY, S.C. 1985. Nemagraptid graptolites from the Middle Ordovician Athens Shale, Alabama. Journal of Paleontology 59(5), 1100-1137.

Finney, S.C. \& Chen, X. 1984. Bergstroemograptus n. gen. crawfordi (Harris) from the Ordovician of western Newfoundland. Canadian Journal of Earth Sciences 21(10), 1194-1199. DOI 10.1139/e84-124

Foerste, A.F. 1923. Notes on Medina, Niagaran and Chester fossils. Bulletin of the Scientific Laboratories of Denison University 20, 37-120.

Fortey, R.A. \& COOPER, R.A. 1986. A phylogenetic classification of the graptoloids. Palaeontology 29(4), 631-654.

Fortey, R.A., Zhang, Y.D. \& Mellish, C. 2005. The relationships of biserial graptolites. Palaeontology 48(6), 1241-1272. DOI 10.1111/j.1475-4983.2005.00510.x

FowLER, G.H. 1892. The morphology of Rhabdopleura normani Allm., 293-297. In Festschrift zum 70ten Geburstag Rudolf Leuckarts. 293 pp. W. Engelmann, Leipzig.

FRECH, F. 1897. Lethaea geognostica oder Beschreibung und Abbildung für die Gebirgs-Formationen bezeichnendsten Versteinerungen. Herausgegeben von einer Vereinigung von Palaeontologen, 1. Teil - Lethaea Palaeozoica, 544-684. E. Schweizerbart'sche Verlagshandlung, Stuttgart.

GE, M.Y. 1988. New materials of Azygograptidae and its significance. Acta Palaeontologica Sinica 27(2), 205-212.

GE, M.Y. 1990. Silurian graptolites from Chengkou, Sichuan. Palaeontologica Sinica, 179, New Series B 26, 1-157.

Gegenbaur, C. 1870. Grundzïge der vergleichenden Anatomie. Zweite, umgearbeitete Auflage. 892 pp. Wilhelm Engelmann, Leipzig.

GeINITZ, H.B. 1852. Die Versteinerungen der Grauwackenformation in Sachsen und den angrenzenden Länder-Abtheilungen. Heft 1. Die Silurische Formation. Die Graptolithen, ein monographischer Versuch zur Beurtheilung der Grauwackenformation in Sachsen und den angrenzenden Länderabtheilungen sowie der Silurischen Formation überhaupt. 58 pp. Verlag von Wilhelm Engelmann, Leipzig.

GeINITZ, H.B. 1866. Review J. Hall: Graptolites of the Quebec Group. Neues Jahrbuch für Mineralogie, Geologie und Palaontologie, Jahrgang 1866, 121-125.

Golikov, A.N. 1969. Novye rannevenlokskiye graptolity semeystva Cyrtograptidae na yugo-zapade Tyan'-Shanya. Paleontologicheskiy Zhurnal 4, 64-75. [English translation: Golikov, A.N. 1969. New early Wenlockian graptolites of the family Cyrtograptidae from southwestern Tien Shan. Paleontological Journal 3(4), 506-519.]

Grant, C.C. 1893. Geological Notes. Read before the Geological Section of the Hamilton Association. Notes on some few fossil organisms. No. 1. Journal and Proceedings of the Hamilton Association for session 1892-93, 9, 113-115.

GüRICH, G. 1908. Leitfossilien. Ein Hilfsbuch zum Bestimmen von Versteinerungen bei geologischen Arbeiten in der Sammlung und im Felde. Erste Lieferung: Kambrium und Silur. 95 pp. Verlag Gebrüder Bornträger, Berlin.

GÜRICH, G. 1928. Über Dawsonia Nicholson, Peltocaris Salter 
und über die Graptolithen-Studien von E. Manck. Zentralblatt für Mineralogie, Geologie und Paläontologie 29B, 531-537.

GuRLEY, R.R. 1896. North American graptolites, new species and vertical ranges. Journal of Geology 4, 63-102, 291-311. DOI $10.1086 / 607425$

GutiérReZ-MarCo, J.C. 1986. Notas sobre el desarrollo y estructura proximal del rhabdosoma en algunos graptolitos ordovicicos del SO. De Europa. Paleontologia I Evolucio 20, 191-201.

Haberfelner, E. 1936. Neue Graptoliten aus dem Gotlandium von Böhmen. Geologica Balkanica 2, 87-95.

Hadding, A. 1915. Om Glossograptus, Cryptograptus och tvenne dem närstaende graptolitsläkten. Geologiska Föreningen i Stockholm Förhandlingar 37, 303-336.

DOI 10.1080/11035891509443516

HAECKel, E. 1866. Generelle Morphologie der Organismen. Allgemeine Grundzüge der organischen Formen-Wissenschaft, mechanisch begründet durch die von Charles Darwin reformirte Descendenz-Theorie. Erster Band: Allgemeine Anatomie der Organismen. 574 pp. Verlag Georg Reimer, Berlin.

HAECKEL, E. 1868. Natürliche Schöpfungsgeschichte. Gemeinverständliche wissenschaftliche Vorträge über die Entwicklungslehre im Allgemeinen und diejenige von Darwin, Goethe und Lamarck im Besonderen, über die Anwendung derselben auf den Ursprung des Menschen und andere damit zusammenhängende Grundfragen der Naturwissenschaft. 568 pp. Verlag Georg Reimer, Berlin.

Halanych, K.M. 1995. The phylogenetic position of the pterobranch hemichordates based on $18 \mathrm{~S}$ rDNA sequence data. Molecular Phylogenetics and Evolution 4, 72-76. DOI 10.1006/mpev.1995.1007

Hall, J. 1847. Paleontology of New York. Volume I. Containing descriptions of the organic remains of the Lower Division of the New-York System (equivalent to the Lower Silurian rocks of Europe). 338 pp. C. Van Benthuysen, Albany.

HaLl, J. 1851. New genera of fossils corals from the Report of James Hall, on the Palaeontology of New York. American Journal of Science 11, 398-401.

HaLl, J. 1858. Report on Canadian Graptolites, 1-39. In Sir William E. Logan's Report of Progress for 1857. Geological Survey of Canada, John Lovell, Montreal.

Hall, J. 1861. Report of the Superintendent of the Geological Survey, exhibiting the progress of the work, January 1, 1861 (including descriptions of new species of fossils from the investigations of the survey). $52 \mathrm{pp}$. Wisconsin Geological Survey, Madison.

Hall, J. 1865. Figures and descriptions of Canadian organic remains. Decade II, Graptolites of the Quebec Group. Geological Survey of Canada. 154 pp. A.B. Dawson Brothers, Montreal.

HaLl, J. 1868. Introduction to the study of the Graptolitidae. New York State Museum Natural History $20^{\text {th }}$ Annual Report, 169-240.

HaLl, J. 1879. Descriptions of new species of fossils from the $\mathrm{Ni}$ agara Formation at Waldron, Indiana. 20 pp. J. Munsell, Printer, Albany, New York. [same as HaLl, J. 1883. Descrip- tions of new species of fossils from the Niagara Formation at Waldron, Indiana. Transactions of the Albany Institute, 57-76.]

HaLL, T.S. 1914. Victorian graptolites, Part 4. Some new or little known species. Proceedings of the Royal Society of Victoria, New Series 27, 104-118.

HARMER, S.F. 1905. The Pterobranchia of the Siboga-Expedition with an account of other species. Siboga Expedition Monograph 26, 1-133.

HARRIS, W.J. 1916. The paleontological sequence of the Lower Ordovician rocks in the Castlemaine District. Proceedings of the Royal Society of Victoria, New Series 29, 50-74.

Harris, W.J. 1926. Victorian graptolites, part II. Proceedings of the Royal Society of Victoria, New Series 38, 55-61.

HARRIs, W.J. 1933. Isograptus caduceus and its allies in Victoria. Proceedings of the Royal Society of Victoria, New Series 46, 79-114.

HaRris, W.J. \& Keble, R.A. 1932. Victorian graptolite zones, with correlations and descriptions of species. Proceedings of the Royal Society of Victoria, New Series 44, 25-48.

Harris, W.J. \& Thomas, D.E. 1940. Victorian graptolites (New Series), Part VIII. Mining and Geological Journal of Victoria 2, 197-198.

Harris, W.J. \& Thomas, D.E. 1941. Victorian graptolites (New Series) Part IX. Zygograptus, a new genus of graptolites. Mining and Geological Journal 2(5), 308-310.

Hemmann, M. 1951. Über Linograptus Frech 1897 und Undagraptus stolzenbergensis n. g. n. sp. aus Ostthüringen. Hallesches Jahrbuch für Mitteldeutsche Erdgeschichte 1(2), 74-75.

HENNIG, W. 1950. Grundzüge einer Theorie der phylogenetischen Systematik. 370 pp. Deutscher Zentralverlag, Berlin.

Hennig, W. 1965. Phylogenetic Systematics. Annual Review of Entomology 10, 978-1016.

DOI 10.1146/annurev.en.10.010165.000525

Hisinger, H. 1837. Lethaea Suecica seu Petrifacta Suecica. Supplementum 1. 124 pp. D.A. Norstedt et filii, Stockholm.

HoLm, G. 1881a. Tvenne nya slägten af familjen Dichograptidae Lapw. Öfversigt af Konglika Vetenskaps-Akademiens Förhandlingar 9, 45-51.

HoLm, G. 1881b. Bidrag till kännedomen om Skandinaviens graptoliter I. Pterograptus, ett nytt graptolitslägte. Öfversigt af Konglika Vetenskaps-Akademiens Förhandlingar 1881(4), 71-84.

Holm, G. 1895. Om Didymograptus, Tetragraptus och Phyllograptus. Geologiska Föreningens I Stockholm Förhandlingar 17, 319-343. [English translation: HoLm, G. 1895. On Didymograptus, Tetragraptus, and Phyllograptus. Geological Magazine 11, 433-441, 481-492.]

DOI 10.1080/11035899509442304

HonG, Y.C. 1957. Discovery of the early Caradocian (Upper Ordovician) graptolites and their stratigraphic meaning. Acta Geologica Sinica 37, 475-511. [in Chinese, Russian abstract]

Hopkinson, J. 1869. On British Graptolites. Journal of the Quekett Microscopical Club 1, 151-166.

Hopkinson, J. 1871. On Dicellograpsus, a new genus of graptolites. Geological Magazine 8, 20-26.

DOI $10.1017 /$ S001675680016087X 
Hopkinson, J. \& Lapworth, C. 1875. Descriptions of the graptolites of the Arenig and Llandeilo rocks of St. David's. Quarterly Journal of the Geological Society 31, 631-672. DOI 10.1144/GSL.JGS.1875.031.01-04.49

HoRst, C.J. VAN DER 1936. Planctosphaera and Tornaria. Quarterly Journal of Microscopical Science 78, 605-613.

Hou, X.G., Aldridge, R.J., Siveter, D.J., Siveter, D.J., WilLiams, M., Zalasiewicz, J. \& Ma, X.Y. 2011. An Early Cambrian Hemichordate Zooid. Current Biology 21, 612-616. DOI 10.1016/j.cub.2011.03.005

Hsü, S.C. 1959. A new graptolite fauna of the Lower Ordovician shale of Tsaidam, Chinghai Province. Acta Palaeontologica Sinica 7, 161-192.

Hsü, S.C. \& Chно, Y.T. 1976. The evolution and systematics of the Family Sinograptidae. Acta Geologica Sinica 1976(2), 121-140.

Hu, S. 2005. Taphonomy and palaeoecology of the early Cambrian Chengjiang biota from eastern Yunnan, China. Berliner paläobiologische Abhandlungen 8, 1-189.

Hudson, G.H. 1915. Ceramograptus ruedemanni, a new genus and species of Graptoloidea, and notes on Urasterella pulchella, Billings. The Ottawa Naturalist 28(10), 129-130.

Hundt, R. 1935. Eine neue Graptolithengattung aus dem deutschen Silur. Forschungen und Fortschritte: Nachrichtenblatt der Deutschen Wissenschaft und Technik 11(10), 130.

HundT, R. 1936. Graptolithenleben und Graptolithensterben im Mitteldeutschen Silurmeer. Zeitschrift für die gesamte Naturwissenschaft 1, 21-37.

HundT, R. 1939 (the book cover states 1940, the internal cover says 1939). Das Mitteldeutsche Graptolithenmeer. 395 pp. Martin Boerner Verlag, Halle (Saale).

HundT, R. 1940. Graptolithen aus den Phycodesschichten Ostthüringens. Beiträge zur Geologie von Thüringen 5, 242-253.

HundT, R. 1942. Beiträge zur Kenntnis des Mitteldeutschen Graptolithenmeers. Beiträge zur Geologie von Thüringen 6, 205-231.

Hundt, R. 1949. Neue Graptolithenfunde aus dem Gotlandium Ostthüringens, 18-23. In HundT, R. Zur Erforschung des Silurs Ostthüringens. Zweigniederlassung Gera: Geologischer Verein von Gera und Umgebung, Thüringer Volksverlag, Weimar.

HundT, R. 1950. Neue Forschungsergebnisse von gotlandischen Graptolithen. Experientia 6, 293-294. DOI 10.1007/BF02170899

HundT, R. 1951. Beitrag zur Kenntnis der mitteldeutschen Graptolithenfauna aus dem Weinbergbruch bei Hohenleuben und dem Hässlich bei Weckersdorf. Jahrbuch des Kreismuseums Hohenleuben-Reichenfels 1, 46-61.

HundT, R. 1953a. Graptolithen. Neue Erkenntnisse über die Leitversteinerungen der Silurformation. Die Neue BrehmBücherei. Heft 103. 112 pp. Akademische Verlagsgesellschaft Geest \& Portig K.-G., Leipzig. [2. edition 2006. Westharp Wissenschaften, Hohenwarsleben].

Hundt, R. 1953b. Eine neue Graptolithengattung (Cameragraptus gen. nov.) aus dem Unteren Gotlandium Ostthüringens. Jahrbuch des Kreismuseums Hohenleuben-Reichenfels $3,1-13$. [no pagination]
HundT, R. 1959. Der Weinbergbruch bei Hohenleuben (Kreis Zeulenroda) ein weltbekannter Graptolithenfundplatz. Jahrbuch der Kreismuseums Hohenleuben, Reichenfels 1959, $5-29$.

HundT, R. 1965. Aus der Welt der Graptolithen. 208 pp. Commercia Verlag, Berlin \& Bonn.

Huo, S.C. 1957. Some Silurian graptolites of the Family Retiolitidae from Liangshan, Hanchung. Acta Palaeontologica Sinica 5, 513-522.

HutT, J.E. 1974. The development of Clonograptus tenellus and Adelograptus hunnebergensis. Lethaia 7, 79-92. DOI 10.1111/j.1502-3931.1974.tb00887.x

Hyman, L.H. 1959. The Invertebrates: Smaller Coelomate Groups, vol. 5: Chapter 17, 72-207. In The enterocoelous coelomates - Phylum Hemichordata. McGraw-Hill Book Company, Inc., New York, London, Toronto.

ICZN 1954a. Opinion 197. Suppression, under the plenary powers, of the generic name "Graptolithus" Linnaeus, 1868 (class Graptolithina) and of the specific name "scalaris" Linnaeus, 1768, as published in the combination "Graptolithus scalaris". Opinions and declarations rendered by the International Commission on Zoological Nomenclature 3(16), 207-216.

ICZN 1954b. Opinion 198. Suppression under the plenary powers, of the generic names "Lomatoceras" Bronn, 1834, and "Monoprion" Barrande, 1850 (Class Graptolithina) and validation of the generic name "Monograptus" Geinitz, 1852. Opinions and declarations rendered by the International Commission on Zoological Nomenclature 3(17), 217-228.

ICZN 1954c. Opinion 199. Suppression, under the Plenary Powers, of the generic name Gladiolites Barrande, 1850, and validation of the name Retiolites Barrande, 1850 (Class Graptolithina). Opinions and declarations rendered by the International Commission on Zoological Nomenclature 3(18), 229-238.

ICZN 1963. Opinion 650. Graptolite generic name: validation of certain emendations under the plenary powers. Bulletin of Zoological Nomenclature 20(2), 105.

JAANUSSON, V. 1960. Graptoloids from the Ontikan and Viruan (Ordov.) limestones of Estonia and Sweden. Bulletin of the Geological Institutions of the University of Uppsala 38 (3-4), 289-366.

JAANUSSON, V. 1965. Two multiramous graptoloids from the Lower Didymograptus Shale of Scandinavia. Geologiska Föreningens i Stockholm Förhandlingar 86(4), 413-432. DOI 10.1080/11035897.1965.9626393

JACKSON, D.E. 1967. Psigraptus, a new graptolite genus from the Tremadocian of Yukon, Canada. Geological Magazine 104(4), 317-321. DOI 10.1017/S0016756800048901

JACKSON, D.E. \& Bulman, O.M.B. 1970. On the generic name Trigonograptus Nicholson, 1869. Proceedings of the Geological Society of London 1663, 107-109.

JACKson, D.E. \& LenZ, A.C. 1999. Occurrences of Psigraptus and Chigraptus gen. nov. in the Tremadoc of the Yukon Territory, Canada. Geological Magazine 136(2), 153-157. DOI 10.1017/S0016756899002332

JACKson, D.E. \& LenZ, A.C. 2003. Taxonomic and biostrati- 
graphical significance of the Tremadoc graptolite fauna from northern Yukon Territory, Canada. Geological Magazine 140(2), 131-156. DOI 10.1017/S0016756802007227

JAEGER, H. 1978. Entwicklungszüge (Trends) in der Evolution der Graptolithen. Schriftenreihe für geologische Wissenschaften $10,5-58$.

JAEGER, H. 1992. Ein dendroider Graptolith (Ophigraptus hercyniae n. g. n. sp.) von der Unter-/Mitteldevon-Grenze im Harz (Deutschland). Paläontologische Zeitschrift 66(1-2), 123-128. DOI 10.1007/BF02989482

JAEKEL, O. 1889. Über das Alter des sog. Graptolithengesteins mit besonderer Berücksichtigung der in demselben enthaltenen Graptolithen. Zeitschrift der deutschen geologischen Gesellschaft 41, 653-716.

JAHN, J.J. 1892. Vorläufiger Bericht über die Dendroideen des Böhmischen Silur. Sitzungsberichte der Kaiserlich-königlichen Akademie der Wissenschaften, Mathematisch-naturwissenschaftliche Klasse 51, Abtheilung 1, 642-649.

JiAO, X. [QIAO, X.] 1977. Kalpinograptus, a new graptolite genus from the Saergan Formation in Kalpin of Xinjiang. Acta Palaeontologica Sinica 16(2), 287-292.

JiAO, S.D. 1981. Some new graptolites from the Ningkuo Formation (Lower Ordovician) of Zhejiang. Acta Palaeontologica Sinica 20(1), 65-70.

JIN, Y. \& WANG, X.F. 1977. The discovery of graptolites in the Baishuxi Formation of the early Ordovician in central Hunan and the multiramous graptolites in the Qiaotingzi Formation. Professional Papers in Stratigraphy and Palaeontology 3, 74-85. [in Chinese]

John, C.C. 1931. Cephalodiscus. Discovery Reports 3, 223-260.

Johnston, K.J., Johnston, P.A. \& Powell, W.G. 2009. A new, Middle Cambrian, Burgess Shale-type biota, Bolaspidella Zone, Chancellor Basin, southeastern British Columbia. Palaeogeography, Palaeoclimatology, Palaeoecology 277, 106-126. DOI 10.1016/j.palaeo.2009.02.015

Kenrick, P., Kvaček, Z. \& Bengtson, S. 1999. Semblant land plants from the Middle Ordovician of the Prague Basin reinterpreted as animals. Palaeontology 42(6), 991-1002. DOI 10.1111/1475-4983.00106

Khaletzskaya, O.N. (also spelled Chaletskaya, O.N.) 1962. Graptolites from the Llandovery of Western Tian-Shan, 54-76. In Verkhov, V.I. et al. (eds) Stratigrafia y paleontologya Uzbekistana y sopredelnich raionov [Stratigraphy and palaeontology of Usbekistan and adjacent regions]. Institut geologii, Akademiya nauk Uzbetskoi S.S.R., Tashkent. [in Russian]

KoJima, J.-I. 2003. Apomorphy-based definition also pinpoints a node, and PhyloCode names prevent effective communication. Botanical Review 69(1), 44-58.

DOI 10.1663/0006-8101(2003)069[0044:ADAPAN]2.0.CO;2

KomAI, T. 1949. Internal structure of the pterobranch Atubaria heterolopha Sato, with an appendix on the homology of the notochord. Proceedings of the Japan Academy 25, 19-24.

Koren', T.N. 1962. Novyi siluriiskii rod Uralograptus. Paleontologicheskiy Zhurnal 3, 137-138.

Konen', T.N. 1979. Pacificograptus - novyy rod pozneordovikskikh diplograptid. Paleontologicheskiy Zhurnal 1979(1),
69-74. [English translation: Pacificograptus, a new Late Ordovician diplograptid genus. Paleontological Journal 13(1), 65-70.]

KOREN', T.N. \& BJERRRESKOV, M. 1997. Early Llandovery monograptids from Bornholm and the southern Urals: taxonomy and evolution. Bulletin of the Geological Society of Denmark $44,1-43$.

Koren', T.N. \& Rickards, R.B. 1996. Taxonomy and evolution of Llandovery biserial graptoloids from the southern Urals, western Kazakhstan. Special Papers in Palaeontology 54, $1-103$.

KozŁowska, A. \& Bates, D.E.B. 2008. Kirkigraptus, a new retiolitid graptolite from Poland. Acta Palaeontologica Polonica 53, 105-112. DOI 10.4202/app.2008.0107

KozŁowska, A., Bates, D.E.B. \& Piras, S. 2010. A new Silurian graptolite, Reticuloplectograptus, and its bearing on retiolitid evolution. Palaeontology 53(6), 1411-1417.

DOI 10.1111/j.1475-4983.2010.01014.x

KozŁowska-DawiDziuK, A. 1990. The genus Gothograptus (Graptolithina) from the Wenlock of Poland. Acta Palaeontologica Polonica 35, 191-209.

KozŁowska-Dawidziuk, A. 1995. Silurian retiolitids of the East European Platform. Acta Palaeontologica Polonica 40, 261-326.

KozŁowska-Dawidziuk, A. 2001. Phylogenetic relationships within the Retiolitidae (Graptolithina) and a new genus, Cometograptus. Lethaia 34, 84-96.

DOI 10.1080/002411601300068314

KozŁowska-Dawidziuk, A. 2004. Evolution of retiolitid graptolites - a synopsis. Acta Palaeontologica Polonica 49(4), 505-518.

KozŁowska-Dawidziuk, A., Lenz, A.C. \& Bates, D.E.B. 2003. A new classification of ancorate diplograptids, 565-569. In Ortega, G. \& Aceñolaza, G.F. (eds) Proceedings of the $7^{\text {th }}$ International Graptolite Conference and Field Meeting of the International Subcommission on Silurian Stratigraphy. 549 pp. INSUGEO, Serie Correlación Geológica, Cumunicarte Editorial, Tucumán.

KozŁowski, R. 1938. Tymczasowe wiadomości o graptolitach $\mathrm{z}$ tremadoku polski i ich teoretycznym znaczeniu [Informations préliminaires sur les Graptolithes du Tremadoc de la Pologne et sur leur portée théorique]. Annales Musei Zoologici Polonici 13, 183-196.

KozŁowsKi, R. 1949. Les graptolithes et quelques nouveaux groups d'animaux du Trémadoc de la Pologne. Palaeontologia Polonica 3, 1-235.

KozŁowski, R. 1951 [often cited as 1952]. O niezwyklym graptolicie ordowickim. Acta Geologica Polonica 2(3), 291-299. [French translation: Sur un remarquable graptolite ordovicien. Acta Geologica Polonica 2, 86-93]

KozŁowski, R. 1954. O budowie nietorych Dichograptidae. Acta Geologica Polonica 4, 423-444. [French translation: Sur la structure de certain dichograptidés. Acta Palaeontologica Polonica 4, 118-135.]

KozŁowski, R. 1956. Nouvelles observations sur les Corynoididae (Graptolithina). Acta Palaeontologica Polonica 1(4), 259-269. 
KozŁowski, R. 1959. Les hydroïdes ordoviciens à squelette chitineux. Acta Palaontologica Polonica 4(3), 209-271.

KozŁowski, R. 1960. Calyxdendrum graptoloides n. gen., n. sp. a graptolite intermediate between the Dendroidea and the Graptoloidea. Acta Palaeontologica Polonica 5(2), 107-125.

KozŁowski, R. 1961. Découverte d'un Rhabdopleuridé (Pterobranchia) ordovicien. Acta Palaeontologica Polonica 6(1), 3-16.

KozŁowski, R. 1962. Crustoidea - nouveau groupe de graptolites. Acta Palaeontologica Polonica 7(1-2), 3-52.

KozŁowski, R. 1963. Le dévelopmement d'un graptolite tuboïde. Acta Palaeontologica Polonica 8(2), 103-134.

KozŁowsKi, R. 1966. Graptolodendrum mutabile n. gen., n. sp. an aberrant dendroid graptolite. Acta Palaeontologica Polonica 11(1), 3-14.

KozŁowski, R. 1967. Sur certain fossiles ordoviciens à teste organique. Acta Palaeontologica Polonica 12(2), 99-132.

KozŁowski, R. 1970. Nouvelles observations sur les Rhabdopleuridés (Ptérobranches) ordoviciens. Acta Palaeontologica Polonica 15(1), 3-17.

KozŁowsKi, R. 1971. Early development stages and the mode of life of graptolites. Acta Palaeontologica Polonica 16(4), 313-341.

Kraft, P. \& Kraft, J. 2003. Middle Ordovician graptolite fauna from Praha - Červený vrch (Prague Basin, Czech Republic). Bulletin of Geosciences 78(2), 129-139.

Kraft, P. \& KRAFT, J. 2008. Planktic dendroids - fiction or reality?, 10. In S̆TORCH, P. \& KRAFT, P. (eds) Workshop on graptolite volume of Treatise on Invertebrate Paleontology and GWG meeting. 51 pp. Prague.

LACÉPÈDE, B.G.E., 1801. Histoire naturelle des poissons 3. i-lxxi + 558 pp. Plassan, Paris.

LANKESTER, E.R. 1877. Notes on the embryology and classification of the animal kingdom; comprising a revision of speculations relative to the origin and significance of the germlayers. Quarterly Journal of Microscopical Science, New Series 17, 339-454.

LAPWORTH, C. 1873a. Notes on the British graptolites and their allies. 1. On an improved classification of the Rhabdophora, part 1. Geological Magazine 10, 500-504.

DOI 10.1017/S0016756800469256

LAPWORTH, C. 1873b. Notes on the British graptolites and their allies. 1. On an improved classification of the Rhabdophora, part 2. Geological Magazine 10, 555-560.

DOI 10.1017/S0016756800469372

LAPWORTh, C. 1876a. The Silurian System in the South of Scotland, 1-9. In Armstrong, J., Young, J. \& Robertson, D. (eds) Catalogue of the Western Scottish Fossils. Blackie \& Son, Glasgow.

LAPWORTH, C. 1876b. On Scottish Monograptidae (concluded from page 507). Geological Magazine (decade II, vol. III) 13, 544-552.

LAPWORTH, C. 1879a. On the geological distribution of the Rhabdophora. Part I. Introduction. Annals and Magazine of Natural History, Series 5(3), 245-257.

LAPWORTH, C. 1879b. On the geological distribution of the Rhabdophora. Part I. Introduction (continued from p. 257). Annals and Magazine of Natural History, Series 5(3), 449-455.
LAPWORTH, C. 1879c. On the geological distribution of the Rhabdophora. Part II. Data (continued from vol. III, p. 455). Annals and Magazine of Natural History, Series 5(4), 333-341.

LAPWORTH, C. 1879d. On the geological distribution of the Rhabdophora. Part II. Data (continued from vol. IV, p. 341). Annals and Magazine of Natural History, Series 5(4), 423-431.

LAPWORTH, C. 1880a. On the geological distribution of the Rhabdophora. Part II. Data (continued from vol. IV, p. 431). Annals and Magazine of Natural History, Series 5(5), 45-62.

LAPWORTH, C. 1880b. On the geological distribution of the Rhabdophora. Part III. Results (continued from vol. V, p. 62). Annals and Magazine of Natural History, Series 5(5), 273-285.

LAPWORTH, C. 1880c. On the geological distribution of the Rhabdophora. Part III. Results (continued from vol. V, p. 285). Annals and Magazine of Natural History, Series 5(5), 358-369.

LAPWORTH, C. 1880d. On the geological distribution of the Rhabdophora. Part III. Results (continued from vol. V, p. 369). Annals and Magazine of Natural History, Series 5(6), 16-29.

LAPWORTH, C. 1880e. On the geological distribution of the Rhabdophora. Part III. Results (continued from vol. VI, p. 29). Annals and Magazine of Natural History, Series 5(6), 185-207.

LAPWORTh, C. 1880f. On new British graptolites. Annals and Magazine of Natural History 5(5), 149-177.

LAPWORTH, C. 1881. On the Cladophora (Hopk.) or Dendroid Graptolites collected by Professor Keeping in the Llandovery Rocks of Mid Wales. Quarterly Journal of the Geological Society of London 37, 171-177.

DOI 10.1144/GSL.JGS.1881.037.01-04.15

LEE, C.K. 1963. Some Middle Ordovician graptolites form Gueizhou. Acta Palaeontologica Sinica 11(4), 554-578.

LEGRAND, P. 1964. Un graptolite remarquable de l'Ordovicien inférieur du Sahara algérien, Choristograptus louhai nov. gen., nov. sp. Bulletin de la Société géologique de France 5(1), 52-57.

Legrand, P. 1987. Modo de desarrollo del suborden Diplograptina (Graptolithina) en el Ordovicico superior y en el Silurico. Implicaciones taxonomicas. Revista Española de Paleontología 2, 59-64.

Lenz, A.C. \& KozŁowska, A. 2007. New and unusual upper Llandovery graptolites from Arctic Canada. Acta Palaeontologica Polonica 52(3), 489-502.

Lenz, A.C. \& KozŁowskA, A. 2010. Sagenograptoides, a new name for the retiolitid graptolite Sagenograptus Lenz and Kozłowska-Dawidziuk, 2001. Journal of Paleontology 84(19), 156.

Lenz, A.C. \& KozŁowska-Dawidziuk, A. 2001. Upper Wenlock (Silurian) graptolites of Arctic Canada: pre-extinction lundgreni Biozone fauna. Palaeontographica Canadiana 20, 1-61.

LenZ, A.C. \& Melchin, M.J. 1987. Silurian retiolitids from the Cape Phillips Formation, Arctic Islands, Canada. Bulletin of the Geological Society of Denmark 35, 161-170.

LenZ, A.C. \& Melchin, M.J. 1997. Phylogenetic analysis of the Silurian Retiolitidae. Lethaia 29, 301-309.

Lenz, A.C., Senior, S., KozŁowska, A. \& Melchin, M.J. 2012. Graptolites from the mid Wenlock (Silurian), Middle and Upper Sheinwoodian, Arctic Canada. Palaeontographica Canadiana 32, 1-93. 
LevinA, E.F. 1928. Graptolity iz Aq-Tengi v Turkestanskom chrebte. Trudy Srednie-aziatskogo gosudarstvennogo universiteta, Series 7a, Geologiya 5, 1-18. [in Russian]

Li, J.J. 1984. Some early Ordovician graptolites from Chongyi, Jiangxi. Acta Palaeontologica Sinica 23(5), 578-585.

LI, J.J. 1994. A revision of some early Ordovician graptolites of China, 61-71. In Chen, X., ERdtmann, B.-D. \& Ni, Y.N. (eds) Graptolite Research Today. 262 pp. Nanjing University Press, Nanjing.

Li, J.J. 1995. Lower Silurian graptolites from the Yangtze Gorge district. Palaeontologica Cathayana 6, 215-344.

Li, J.J. \& GE, M.Y. 1981. Development and systematic position of akidograptids. Acta Palaeontologica Sinica 20, 225-234. [in Chinese with English abstract]

LI, J.J., GE, M.Y. \& ChEN, X. 1987. Ordovician graptolites from Taishan, Guandong. Bulletin of Nanjing Institute of Geology and Palaeontology, Academia Sinica 12, 95-134.

LI, Z.M. \& LI, D.Q. 1985. Appendispinograptus, a new subgenus of Climacograptus Journal of the Wuhan College of Geology 10 (supplement), 35-42. [in Chinese with English summary]

Lin, Y.K. 1980. Ordosograptus - a new graptolite genus and its affinities. Acta Palaeontologica Sinica 19(6), 475-482.

LiN, Y.K. 1981. New materials of graptodendroids with special reference to the classification of Graptodendroidea. Bulletin of Nanjing Institute of Geology and Palaeontology, Academia Sinica 3, 242-262.

LiN, Y.K. 1986. A new planktonic graptolite fauna, 224-254. In Chen, Y.J. (ed.) Aspects of Cambrian-Ordovician boundary in Dayangcha, China. China Prospect Publishing House, Beijing.

LindHolm, K. 1991. Ordovician graptolites from the early Hunneberg of southern Scandinavia. Palaeontology 34(2), 283-327.

LiNDHOLM, K. \& MALETZ, J. 1989. Intraspecific variation and relationships of some Lower Ordovician species of the dichograptid, Clonograptus. Palaeontology 32(4), 711-743.

Linneus, C. 1735. Systema naturce, sive regna tria naturce systematice proposita per classes, ordines, genera, and species. 12 pp. Lugduni Batavorum. (Haak).

[http://www.biodiversitylibrary.org/item/15373]

LinNeus, C. 1758. Systema naturce per regna tria naturce, secundum classes, ordines, genera, species, cum characteribus, differentiis, synonymis, locis. Tomus I. Editio decima, reformata. 824 pp. Salvius, Holmiæ. http://reader.digitalesammlungen.de/resolve/display/bsb10076014.html; http://www.biodiversitylibrary.org/item/10277

LinNeus, C. 1768. Systema naturce per regna tria naturce, secundum classes, ordines, genera, species, cum characteribus and differentiis. Tomus III. 236 pp. Salvius, Holmiæ. http://gdz.sub.uni-goettingen.de/dms/load/img/?PPN=PPN36 2053855andIDDOC $=215259$

LoDucA, S.T. 1990. Medusaegraptus mirabilis as a noncalcified dasyclad alga. Journal of Paleontology 64, 469-474.

LOYDELL, D.K. 1991. The biostratigraphy and formational relationships of the upper Aeronian and lower Telychian (Llandovery, Silurian) formations of western mid-Wales.
Geological Journal 26(3), 209-244.

DOI 10.1002/gj.3350260304

LOYDELL, D.K. 1992. Upper Aeronian and Lower Telychian (Llandovery) graptolites from western Mid-Wales. Part 1. Monograph of the Palaeontographical Society of London 146(589), 1-55.

LoydelL, D.K. 1993. Upper Aeronian and Lower Telychian (Llandovery) graptolites from western Mid-Wales, Part 2. Monograph of the Palaeontographical Society of London 147(592), 56-180.

Loydell, D.K. \& MaletZ, J. 2004. The Silurian graptolite genera Streptograptus and Pseudostreptograptus. Journal of Systematic Palaeontology 2, 65-93. DOI 10.1017/S1477201904001117

LoydelL, D.K. \& NestoR, V. 2006. Isolated graptolites from the Telychian (Upper Llandovery, Silurian) of Latvia and Estonia. Palaeontology 49(3), 585-619.

DOI 10.1111/j.1475-4983.2006.00550.x

LuKasiK, J.J. \& Melchin, M.J. 1994. Atavograptus primitivus (Li) from the earliest Silurian of Arctic Canada: Implications for monograptid evolution. Journal of Paleontology 68(5), 1159-1163.

LuKASIK, J.J. \& MELChIN, M.J. 1997. Morphology and classification of some early Silurian monograptids (Graptoloidea) from the Cape Phillips formation, Canadian Arctic Islands. Canadian Journal of Earth Sciences 34(8), 1128-1149.

DOI 10.1139/e17-091

M'Coy, F. 1850. On some new genera and species of Silurian Radiata in the Collection of the University of Cambridge. Annals and Magazine of Natural History, Series 2(6), 270-290.

M'Coy, F. 1876. On a new Victorian graptolite. Annals and Magazine of Natural History Series 4(18), 128-130.

M'Intosh, W.C. 1882. Preliminary notice of Cephalodicus, a new type allied to Prof. Allman's Rhabdopleura, dredged in H.M.S. 'Challenger'. Annals and Magazine of Natural History ( $5^{\text {th }}$ Series $) 10,337-348$.

MALETZ, J. 1992. The proximal development in anisograptids (Graptoloidea, Anisograptidae). Paläontologische Zeitschrift 66(3/4), 297-309. DOI 10.1007/BF02985821

MaleTZ, J. 1993. A possible abrograptid graptolite (Abrograptidae, Graptoloidea) from western Newfoundland. Paläontologische Zeitschrift 67(3/4), 323-329. DOI 10.1007/BF02990285

MaletZ, J. 1994a. Pendent Didymograptids (Graptoloidea, Dichograptina), 27-43. In Chen, X., Erdtmann, B.-D. \& Ni, Y.N. (eds) Graptolite Research Today. 262 pp. Nanjing University Press, Nanjing.

Maletz, J. 1994b. The rhabdosome architecture of Pterograptus (Graptoloidea, Dichograptidae). Neues Jahrbuch für Geologie und Paläontologie, Abhandlungen 191(3), 345-356.

MaLETZ, J. 1997. Graptolites from the Nicholsonograptus fasciculatus and Pterograptus elegans Zones (Abereiddian, Ordovician) of the Oslo Region, Norway. Greifswalder Geowissenschaftliche Beiträge 4, 5-100.

MALETZ, J. 1998. Undulograptus dicellograptoides n. sp., an abnormal diplograptid from the Late Arenig of western New- 
foundland, Canada. Paläontologische Zeitschrift 72(1/2), 111-116. DOI 10.1007/BF02987820

MaleTz, J. 2001. Graptolite research in Germany [Hanns Bruno Geinitz Symposium]. Geologica Saxonica, Abhandlungen des Staatlichen Museums für Mineralogie und Geologie Dresden 46/47, 169-180.

MaLeTZ, J. 2004. Isolated Chewtonian (Lower Ordovician) graptolites from western Newfoundland. Paläontologische Zeitschrift 78(1), 173-187. DOI 10.1007/BF03009137

Maletz, J. 2010. Xiphograptus and the evolution of virgellabearing graptoloids. Palaeontology 53(2), 415-439. DOI 10.1111/j.1475-4983.2010.00940.x

Maletz, J. 2011a. The identity of the Ordovician (Darriwilian) graptolite Fucoides dentatus Brongniart, 1828. Palaeontology 54(4), 851-865. DOI 10.1111/j.1475-4983.2011.01068.x

MaletZ, J. 2011b. Climacograptus pungens Ruedemann, 1904 and the definition of the Darriwilian (Ordovician) graptolite genus Archiclimacograptus Mitchell, 1987. Canadian Journal of Earth Sciences 48, 1355-1367. DOI 10.1139/e11-038

Maletz, J. 2011c. The proximal development of the Middle Ordovician graptolite Skanegraptus janus from the Krapperup drill core of Scania, Sweden. GFF 133, 49-56.

DOI 10.1080/11035897.2011.564293

MALETZ, J. 2011d. Scandinavian isograptids (Graptolithina; Isograptidae): Biostratigraphy and Taxonomy. Proceedings of the Yorkshire Geological Society 58(4), 267-280.

MaletZ, J. 2014. Fossil Hemichordata (Pterobranchia, Enteropneusta). Palaeogeography, Palaeoclimatology, Palaeoecology 398, 16-27. DOI 10.1016/j.palaeo.2013.06.010

Maletz, J., Carlucci, J. \& Mitchell, C.E. 2009. Graptoloid cladistics, taxonomy and phylogeny. Bulletin of Geosciences 84(1), 7-19. DOI 10.3140/bull.geosci.1108

Maletz, J. \& KozŁowsKa, A. 2013. Ordovician graptolites from the Yichang area, Hubei, China. Paläontologische Zeitschrift 87, 445-454. DOI 10.1007/s12542-013-0174-4

Maletz, J. \& Mitchell, C.E. 1996. Evolution and phylogenetic classification of the Glossograptidae and Arienigraptidae (Graptoloidea): new data and remaining questions. Journal of Paleontology 70(4), 641-655.

Maletz, J. \& SlovaceK, M. 2013. Lower Ordovician (Dapingian) Baltograptus species (Graptolithina) in Dalarna, Sweden. Palaeontology 56(5), 1107-1120. DOI 10.1111/pala.12038

Maletz, J., Steiner, M. \& FatKa, O. 2005. Middle Cambrian pterobranchs and the question: What is a graptolite? Lethaia 38, 73-85. DOI 10.1080/00241160510013204

MANCK, E. 1923. Untersilurische Graptolithenarten der Zone 10 des Obersilurs, ferner Diversograptus gen. nov. sowie einige neue Arten anderer Gattungen. Natur (Leipzig) 14, 282-289.

Matthew, G.F. 1886. Illustrations of the fauna of the St. John Group, III. Descriptions of new genera and species (including the description of a new species of Solenopleura by J.F. Whiteaves). Transactions of the Royal Society of Canada 3, 29-84.

McKaY, B.D. \& ZINK, R.M. 2010. The causes of mitochondrial DNA gene tree paraphyly in birds. Molecular Phylogenetic and Evolution 54, 647-650.

DOI 10.1016/j.ympev.2009.08.024
McLearn, F.H. 1915. The Lower Ordovician (Tetragraptus zone) at St. John, New Brunswick. American Journal of Science 40, 49-59. DOI 10.2475/ajs.s4-40.235.49

Melchin, M.J. 1998. Morphology and phylogeny of some Early Silurian 'diplograptid' genera from Cornwallis island, Arctic Canada. Palaeontology 41, 263-315.

Melchin, M.J. 1999. Origin of the Retiolitidae: insights from a new graptolite genus from the early Silurian of Arctic Canada. Lethaia 32, 261-269. DOI 10.1111/j.1502-3931.1999.tb00544.X

Melchin, M.J., Mitchell, C.E., NaczK-Cameron, A., Fan, J.X. \& Loxton, J. 2011. Phylogeny and adaptive radiation of the Neograptina (Graptoloidea) during the Hirnantian mass extinction and Silurian recovery. Proceedings of the Yorkshire Geological Society 58(4), 281-309.

DOI 10.1144/pygs.58.4.301

MierZeJewSKI, P. 1978. Tuboid graptolites from erratic boulders of Poland. Acta Palaeontologica Polonica 23(4), 557-475.

MierzeJewski, P. 1986a. Ultrastructure, taxonomy and affinities of some Ordovician and Silurian organic microfossils. Palaeontologia Polonica 47, 129-220.

MierzeJewski, P. 1986b. New aberrant sessile graptolites from glacial boulders. Acta Palaeontologica Polonica 30(3-4), 191-199.

MierZeJewSKi, P. 1991. Estoniocaulis Obut et Rotsk, 1958 and Rhadinograptus Obut, 1960 are not graptolites. Acta Palaeontologica Polonica 36(1), 77-81.

MierZEJewSKi, P. 2000. An aberrant encrusting graptolite from the Ordovician of Estonia. Acta Palaeontologica Polonica 45, 239-250.

MierZEJewSKi, P. 2001. A new graptolite intermediate between the Tuboidea and the Camaroidea. Acta Palaeontologica Polonica 46(3), 367-376.

Mikhailova, N.F. 1975. Graptolity, 151-158. In Menner, V.V. (ed.) Kharacteristika fauny progranichnych sloev silura i devona tsentralnogo Kazakhstana. Nedra, Moskva. [in Russian]

Miller, S.A. 1874. Genus Megalograptus. The Cincinnati Quarterly Journal of Science 1, 343-346.

M'Intosh, W.C. 1882. Preliminary notice of Cephalodicus, a new type allied to Prof. Allman's Rhabdopleura, dredged in H.M.S. 'Challenger'. Annals and Magazine of Natural History ( $5^{\text {th }}$ Series) $10,337-348$.

M'Intosh, W.C. 1887. Report on Cephalodiscus dodecalophus, M'Intosh, a new type of the Polyzoa, procured on the voyage of H.M.S. Challenger during the years 1873-76 (with an appendix, pp. 38-47, by S. Harmer on the anatomy of Cephalodiscus). Challenger Reports, Zoology 20, 1-47.

Mitchell, C.E. 1987. Evolution and phylogenetic classification of the Diplograptacea. Palaeontology 30(2), 353-405.

Mitchell, C.E. 1988. The morphology and ultrastructure of Brevigraptus quadrithecatus n. gen., n. sp. (Diplograptacea), and its convergence upon Dicaulograptus hystrix (Bulman). Journal of Paleontology 62(3), 448-463.

Mitchell, C.E. 1994. Astogeny and rhabdosome architecture of graptolites of Undulograptus austrodentatus species group, 49-60. In Chen, X., Erdtmann, B.-D. \& Ni, Y.N. (eds) 
Graptolite Research Today. 262 pp. Nanjing University Press, Nanjing.

Mitchell, C.E., Goldman, D., Klosterman, S.L., Maletz, J., SheEts, H.D. \& Melchin, M.J. 2007. Phylogeny of the Diplograptoidea. Acta Palaeontologica Sinica 46 (Suppl.), 332-339.

Mitchell, C.E. \& Maletz, J. 1995. Proposal for adoption of the base of the Undulograptus austrodentatus Biozone as a global Ordovician stage and series boundary level. Lethaia 28, 317-331. DOI 10.1111/j.1502-3931.1995.tb01822.x

Mitchell, C.E., Maletz, J. \& Goldman, D. 2009. What is Diplograptus? Bulletin of Geosciences 84(1), 27-34.

Mitchell, C.E., Maletz, J. \& Zhang, Y.D. 1995. Evolutionary origins of the Diplograptina. The Pacific Section Society for Sedimentary Geology (SEPM), Book 77, 401-404.

Mitchell, C.E. \& Melchin, M.J. 2011. Graptolite phylogeny, disparity and taxa. Treatise Newsletter 2.2011, 33-39.

Mitchell, C.E., Melchin, M.J., Cameron, C.B. \& Maletz, J. 2010. Phylogeny of the tube-bearing Hemichordata reveals that Rhabdopleura is an extant graptolite. IPC3, Abstracts, 283.

Mitchell, C.E., Melchin, M.J., Cameron, C.B. \& Maletz, J. 2013. Phylogenetic analysis reveals that Rhabdopleura is an extant graptolite. Lethaia 46, 34-56. DOI 10.1111/j.1502-3931.2012.00319.x

MoBerg, J.C. 1892. Om några nya graptoliter från Skånes Undre graptolitskiffer. Geologiska Föreningens i Stockholm Förhandlingar 14(4), 339-350.

DOI 10.1080/11035899209447913

Moberg, J.C. \& Törnquist, S.L. 1909. Retiolitoidea från Skånes Colonusskiffer. Sveriges Geologiska Undersökning, Serie C 213, 1-20.

Monsch, K.A. 2006. The PhyloCode, or alternative nomenclature: Why it is not beneficial to palaeontology, either. Acta Palaeontologica Polonica 51(3), 521-524.

Monsen, A. 1925. Über eine neue ordovizische Graptolithenfauna. Norsk geologisk Tidsskrift 8, 147-187.

Monsen, A. 1937. Die Graptolithenfauna im Unteren Didymograptus Schiefer (Phyllograptusschiefer) Norwegens. Norsk geologisk Tidsskrift 16(2-4), 57-267.

Mu, A.T. 1950. [also: Mu, E.Z.] On the evolution and classification of graptolites. Geological Review 15, 171-183. [in Chinese]

Mu, A.T. 1955. On Spirograptus Gürich. Acta Palaeontologica Sinica 3(1), 6-10.

Mu, A.T. 1957. Some new or little known graptolites from the Ningkuo Shale (Lower Ordovician) of Changshan, western Chekiang. Acta Palaeontologica Sinica 5(3), 369-437.

Mu, A.T. 1958. Abrograptus, a new graptolite genus from the Hulo Shale (Middle Ordovician) of Kiangshan, western Chekiang. Acta Palaeontologica Sinica 6(3), 259-265.

Mu, A.T. 1963a. Research into the graptolite faunas of Chilianshan. Scientia Sinica 12, 347-371.

$\mathrm{Mu}$, A.T. 1963b. On the complication of the graptolite rhabdosome. Acta Palaeontologica Sinica 11, 346-377. [in Chinese with English summary]

Mu, A.T. 1974. Evolution, classification and distribution of
Graptoloidea and graptodendroids. Scientia Sinica 17(2), 227-238.

Mu, A.T. \& CHEN, X. 1962. Sinodiversograptus multibrachiatus gen. et sp. nov. and its developmental stages. Acta Palaeontologica Sinica 10, 143-154.

Mu, A.T. \& Chen, X. 1962. Graptolites of China. 171 pp. Science Press, Beijing. [in Chinese]

Mu, A.T., Ge, M.Y., Chen, X., Ni, Y.N. \& Lin, Y.K. 1979. Lower Ordovician graptolites of southwest China. Palaeontologica Sinica (New Series B) 156(13), 1-192.

Mu, A.T. \& LEE, K.C. 1958. Scandent graptolites from the Ningkuo Shale of the Kiangshan-Changshan area, western Chekiang. Acta Palaeontologica Sinica 6, 391-427.

Mu, A.T., LeE, C.K. \& GeH, M.Y. 1960. Ordovician graptolites from Xinjiang (Sikiang). Acta Palaeontologica Sinica 8(1), 27-39.

Mu, A.T., LeE, C.H., GeH, M.Y. \& YIN, J.X. 1962. Graptolites from Chilianshan. Geology of Chilianshan 4. 168 pp. Science Press, Beijing.

Mu, A.T., Li, J.J., Ge, M.Y., Chen, X., Lin, Y.K. \& Ni, Y.N. 1993. Upper Ordovician graptolites of Central China Region. Palaeontologia Sinica, New Series B, 189(29), 1-393. [in Chinese with English summary]

Mu, A.T., Li, J.J., Ge, M.Y., Chen, X., NI, Y.N., Lin, Y.K. \& Mu, X. 1974. Graptolites, 154-164. In Nanjing Institute of GeOLogy and Palaeontology, Academia Sinica (ed.) A Handbook of the Stratigraphy and Palaeontology of Southwest China. 454 pp. Nanjing Institute of Geology and Palaeontology, Nanjing.

Mu, A.T., Li, J., GE, M., Lin, Y.\& Ni, Y. 2002. Fossil Graptolites of China. XIV + 1205 pp. Nanjing University Press, Nanjing.

Mu, A.T. \& LIN, Y.K. 1984. Graptolites from the Ordovician- Silurian boundary sections of Yichang area, S. Hubei, 45-73. In Naning Institute of Geology and Palaeontology, AcadeMIA SINICA (ed.) Stratigraphy and palaeontology of systemic boundaries in China, Ordovician-Silurian boundary 1. 516 pp. Anhui Science and Technology Publishing House, Hefei.

Mu, A.T. \& NI, Y.N. 1975. Silurian and Devonian graptolites from the Qomolangma Feng Region. Report of Scientific Investigation in the Qomolangma Feng Region, Palaeontology $1,1-27$.

Mu, A.T. \& Qiao, X.D. 1962. New materials of Abrograptidae. Acta Palaeontologica Sinica 10(1), 1-8.

Muir, L.A. 1999. A cladistic analysis of some Llandovery (Silurian) Monograptidae. 64 pp. Unpublished MSc. thesis, University of Bristol.

Muir, L.A., Zhang, Y.-D. \& Lin, J.-P. 2013. New material from the Ordovician of China indicates that Inocaulis is a graptolite. Alcheringa 37, 565-566.

DOI 10.1080/03115518.2013.805622

MüNCH, A. 1931. Retiolites mancki, ein neuer Retiolites aus dem norddeutschen Geschiebe. XXIII Bericht Naturwissenschaftliche Gesellschaft Chemnitz, 35-42.

Murchison, R.I. 1867. Siluria. $4^{\text {th }}$ edition (CARruthers, W. 1867. Appendix D, 538-541). John Murray, London.

Ni, Y.N. 1978. Lower Silurian graptolites from Yichang, western Hubei. Acta Palaeontologica Sinica 17(4), 387-416. [in Chinese with English abstract] 
NI, Y.N. 1981. Two new graptolite genera from the Ningkuo Formation (Lower Ordovician) of Wuning, North Jiangxi. Geological Society of America Special Paper 187, 2103-2107.

Nicholson, H.A. 1867a. On some fossils from the Lower Silurian rocks of the south of Scotland. Geological Magazine 1(4), 107-113.

Nicholson, H.A. 1867b. On a new genus of graptolites, with notes on reproductive bodies. Geological Magazine 4, 256-263. DOI 10.1017/S0016756800208649

Nicholson, H.A. 1868. Notes on Helicograpsus, a new genus of graptolites. Annals and Magazine of Natural History, Series $4(2), 23-26$.

Nicholson, H.A. 1869. On some new species of graptolites. Annals and Magazine of Natural History, London, Series 4(4), 231-242.

Nicholson, H.A. 1872a. A Manual of Palaeontology for the use of students with a general introduction on the Principles of Palaeontology. 601 pp. Blackwood \& Sons, Edinburgh \& London.

Nicholson, H.A. 1872b. A monograph of the British Graptolitidae. X + 133 pp. Blackwood \& Sons, Edinburgh \& London.

Nicholson, H.A. 1873. On some fossils from the Quebec Group of Point Lévis, Quebec. Annals and Magazine of Natural History, Series 4(11), 133-143.

Nicholson, H.A. 1875. On a new genus and some new species of graptolites from the Skiddaw Slates. Annals and Magazine of Natural History, Series 4(16), 269-273.

Nicholson, H.A. 1876. Notes on the correlation of the graptolitic deposits of Sweden with those of Britain. Geological Magazine 13, 245-249.

NindEL, F. 1949. Undograptus nodosus nov. spec. von Raitzhain bei Ronneburg, Beitrag von Fr. Nindel aus Bärenwalds im Erzgebirge und Bemerkungen vom Verfasser, 24-25. In Hund, R. Zur Erforschung des Silurs Ostthüringens. Zweigniederlassung Gera: Geologischer Verein von Gera und Umgebung, Thüringer Volksverlag, Weimar.

Nordal, I. \& Stedje, B. 2005. Paraphyletic taxa should be accepted. Taxon 54, 5-6. DOI 10.2307/25065296

Norman, A.M. 1869. Shetland Final Dredging Report. Part 2. On the Crustacea, Tunicata, Polyzoa, Echinodermata, Actinozoa, Hydrozoa and Porifera. Reports of the British Association of the Advancement of Science 38, 247-336.

NutTing, C.C. 1905. Hydroids of the Hawaiian Islands collected by the steamer Albatross in 1902. Bulletin of the United States Fish Commission (for 1903) 23, 931-959.

OвRHel, J. 1959. Ein Landpflanzenfund im mittelböhmischen Ordovizium. Geologie 8, 535-541.

Oвuт, A.M. 1949. Polevoi atlas rukovodyashchikh graptolitov verkhnego silura Kirgizskoi SSR. 56 pp. Kirgizkii filial Akademii nauk SSSR, Geologicheskii institut, Frunze. [in Russian]

Oвuт, A.M. 1950. Semeistva i nekotorye nody odnoryadnykh graptolitov. Voprosy paleontologii (Questions of Paleontology) 1, 264-272. [in Russian]

Oвut, A.M. 1953. Dendroidei severo-zapada Russkoj platformi. Trudy Vsesoyuznogo nepfhtyanovo nautchno-issledovatelsko- go geologo-rasvedotchnogo instituta (VNIGRI), N.S. 78, 26-57. [in Russian]

Oвит, A.M. 1957. Klassifikatsiya i ukazatel rodov graptolitov. Ezhegodnik Vsesoyuznogo paleontologicheckogo obsehchectva 16, 11-47. [in Russian]

OвUт, А.M. 1960. Korrelyatsiya nekotorykh chastei razreza ordovikskikh i siluriiskikh otlozhenii Estonskoi SSR po graptolitam [Correlation on some parts of Estonian Ordovician and Silurian deposits according to graptolites]. Eesti NSV Teaduste Akadeemia, Geoloogia Instituudi Uurimused 5, 143-157. [in Russian]

Oвuт, A.M. 1964. Podtip Stomochordata. Stomokhordovye, 279-337. In OrLov, Y.A. (ed.) Osnovy paleontogii: Echinodermata, Hemichordata, Pogonophora, Chaetognatha. Nedra Press, Moscow. [in Russian]

Oвuт, A.M. 1974. New graptolites from the Middle Cambrian of the Siberian Platform. Special Papers in Palaeontology 13, 9-13.

Oвuт, A.M. 1987. Cochlograptus - a new genus of the Silurian graptolites. Trudy Instituta geologii i geofiziki (Novosibirsk) $388,140-145$.

Овит, A.M. \& RүтZк, G.V. 1958. Ordovikskie i siluriyskie dendroidei Estonii. Eesti NSV Geoloogia Instituudi Uurimused 3, 125-144. [in Russian]

Oвuт, A.M. \& SenNikov, N.V. 1984. Graptolites and zonal subdivisions Lower Ordovician of the Gorny Altai, 53-106. Academy of Sciences of the USSR, Siberian branch, Institute of Geology and Geophysics, Transactions 565, 1-122.

Oвut, A.M. \& Sennikov, N.V. 1985. Osobennosti llandoveriyskich planktontovich soobschestv Sibirskoy Platformi [A pecularity of Llandovery planktic assemblages of the Siberian Platform], 51-60. In Betechtuna, O.A. \& Zhuravleva, I.T. (eds) Sreda i zhizn v geologicheskhom proshlom (paleobasseiny i ich obitateli). Trudy Instituta Geologii i Geofiziki, Nauka Publishing House, Novosibirsk 628. [in Russian]

Oвuт, A.M. \& SenNiKov, N.V. 1987. Oepikograptus, peculiar genus of Middle Ordovician diplograptids (graptolites) [Translated from original Russian title]. Annual of the All-Union Paleontological Society, Leningrad 1987, "Nauka" Publishers, Leningrad Branch 30, 192-198. [in Russian]

Oвut, A.M. \& Sobolevskaya, R.F. 1962. Problemy neftegazonosti Sovetskoi Arktiki: Paleontologiya i biostratigrafiya: Graptolity rannego ordovika na Taimyre. Trudy Nautchnoissledovatelskogo instituta geologii Arktiki 127(3), 65-85. [in Russian]

Oвut, A.M. \& SobolevsKayA, R.F. 1964. Graptolity ordovika Taimyra. 91 pp. Nauka, Moskva. [in Russian]

Oвut, A.M. \& Sobolevskaya, R.F. 1966. Graptolity rannego silura v Kazakhstane. 56 pp. Nauka, Moskva. [in Russian]

Oвut, A.M. \& Sobolevskaya, R.F. 1967. Nekotorye stereostolonaty pozdnego kembriya i ordovika Noril'skogo rayona [Some stereostolonates of the late Cambrian and Ordovician of the Norilsk Region], 45-64. In IvanovskiY, A.B. \& SoкоLov, B.S. (eds) Novye dannye po biostratigrafii nizhnego paleozoya Sibirskoy platformy. Nauka, Moskva. [in Russian]

Obut, A.M., Sobolevskaya, R.F. \& Merkureva, A.P. 1968. Graptolity llandoveri $v$ kernakh burovykh skvazhin Noril'skogo rayona. 137 pp. Nauka, Moskva. [in Russian] 
Obut, A.M. \& Zaslavskaya, N.M. 1976. New data on the early stages of Retiolitidae development, 119-127. In KaLJo, D. \& KOREN', T.N. (eds) Graptolites and Stratigraphy. Academy of Sciences of Estonian SSR, Institute of Geology, Tallinn.

Obut, A.M. \& Zaslavskaya, N.M. 1983. Semeyestva retiolitid i ikh filogeneticheskie otnosheniya [Retiolitid family and their phylogenetic relations], 103-113. In DAGYS, A.S. \& DuBATOLOv, V.N. (eds) Morphologiya i sistematika bespozvonochnykh fanerozoya. Nauka, Moskva. [in Russian]

Oвuт, A.M. \& ZuBtzov, E.I. 1964. Stratigraphy and graptolites from mountain range around the Narynskaya depression. Akademiya nauk SSR, Sibirskoe otdelenie, Institut geologii i geofiziki 10, 320.

ÖPIK, A.A. 1928. Beträge zur Kenntnis der Kukruse - $\left(\mathrm{C}_{2}-\mathrm{C}_{3}\right)$ Stufe in Eesti. III. Acta et Commentationes Universitatis Tartuensis 13, 1-42.

ÖPIK, A.A. 1930. Beträge zur Kenntnis der Kukruse - $\left(\mathrm{C}_{2}-\mathrm{C}_{3}\right)$ Stufe in Eesti. IV. Acta et Commentationes Universitatis Tartuensis 15, 1-34.

Padian, K., Lindberg, D.R. \& Polly, P.D. 1994. Cladistics and the fossil record: the uses of history. Annual Review of Earth Planetary Science 22, 63-91. DOI 10.1146/annurev.ea.22.050194.000431

Page, A., Wilby, P.R., Mellish, C.J.T., Williams, M. \& ZalaSIEWICZ, J.A. 2009. Dawsonia Nicholson: linguliform brachiopods, crustacean tail-pieces and a problematicum rather than graptolite ovarian vesicules. Earth and Environmental Science Transactions of the Royal Society of Edinburgh 99, 251-266. DOI 10.1017/S175569100900704X

PAŠKEVIČIUS, J. 1976. On some new Llandoverian diplograptids of the eastern Baltic, 140-151. In KALJO, D. \& KorEN', T.N. (eds) Graptolites and Stratigraphy. Academy of Sciences of Estonian SSR, Institute of Geology, Tallinn.

PAŠKEVIČIUS, J. 2011. The Ordovician and Silurian graptolites of Lithuania. 107 pp. Lambert Academic Publishing, Saarbrücken.

Peterson, K.J., Su, Y.H., Arnone, M.I., Swalla, B. \& King, B.L. 2013. MicroRNAs support monophyly of enteropneust hemichordates. Journal of Experimental Zoology, Part B, Molecular and Developmental Evolution 9999, 1-7.

PIRAS, S. 2006. Valentinagraptus, a new genus of plectograptid graptoloid from the lower Ludlow (Silurian) of Barrandian, Bohemia. Geological Journal 41, 581-590. DOI 10.1002/gj.1059

PočTA, P. 1894. Système silurien du centre de la Bohême par Joachim Barrande. V Partie: Recherches Paléontologiques. Continuation éditée par le Musée Bohême. Vol. VIII Tome I". Bryozoaires. Hydrozoaires et partie des Anthozoaires. 230 pp. Published by the author, Prague.

Poulsen, C. 1924. Syrrhipidograptus Nathorsti, a new graptolite genus from the Ordovician of Bornholm. Meddelser fra Dansk geologisk Forening 6(25), 1-7.

Poulsen, C. 1937. On the Lower Ordovician faunas of east Greenland. Meddelelser om Groenland 119(3), 1-72.

Poulsen, C. 1943. Procyrtograptus garboi, a new graptolite from the Lower Silurian of Bornholm. Bulletin of the Geological Society of Denmark 10(3), 301-306.
PřIBYL, A. 1941. Pernerograptus nov. gen. a jeho zástupci z českého a cizího siluru. [Pernerograptus nov. gen. und seine Vertreter aus dem böhmischen und ausländischen Silur]. Věstník Královské České společnosti nauk, Tř́da matematicko-přirodovědecká 1941, 1-19 [1-7, 15-18: in Czech; 8-14: in German].

P̌̌IBYL, A. 1943. Revision der Pristiograpten aus den Untergattungen Colonograptus n. subgen. und Saetograptus n. subg. Mitteilungen der Tschechischen Akademie der Wissenschaften 1942, 52(15), 1-22.

PřiBYL, A. 1947. Classification of the genus Climacograptus Hall, 1865. Rozpravy České akademie věd a umění, Třída II (matematicko-př́rodovědecká) 57(2), 1-10. [in Czech]

Pর̌ıBYL, A. 1948a. Bibliographic index of Bohemian Silurian graptolites. Knihovna Státního geologického ústavu Republiky československé 22, 1-97.

PřIBYL, A. 1948b. Some new subgenera of graptolites from the Families Dimorphograptidae and Diplograptidae. Věstník Státního geologického ústavu Československé republiky 23, $37-48$.

PřIBYL, A. 1949. Revision of the Diplograptidae and Glossograptidae of the Ordovician of Bohemia. Bulletin international de l'Académie tchèque des Sciences 50(1), 1-51.

PřiBYl, A. 1967a. O rodu Bohemograptus gen. nov. (Graptoloidea) z českého a cizího ludlowu (Zur Gattung Bohemograptus gen. nov. (Graptolitoidea) aus dem böhmischen und fremden Ludlovium. Časopis Národního muzea, Oddíl prírodovědný 3, 133-136.

PřIBYL, A. 1967b. Monograptus (Testograptus) subg. n. aus dem böhmischen und europäischen Silur. Věstník Ústředního ústavu geologického 42, 49-52.

PřIBYL, A. 1981. New graptolites of the family Monograptidae from the Upper Silurian of Bohemia. Věstník Ústředního ústavu geologického 56, 371-375.

Pर̌ibYl, A. \& Šтorch, P. 1983. Monograptus (Stimulograptus) subgen. n. (Graptolites) from the Lower Silurian of Bohemia. Věstnik Ústředního ústavu geologického 58(4), 221-225.

Pर̌ıibl, A. \& ŠToRCh, P. 1985. Prochnygraptus gen. n. (Graptolithina, Monograptidae) from the middle and upper Llandovery of Europe. Věstník Ústředního ústavu geologického 60(2), 159-164.

RadZevičius, S. 2007. The genus Pristiograptus in Wenlock of East Baltic and the Holy Cross Mountains. Dissertationes Geologicae Universitatis Tartuensis 20, 1-57.

RichteR, R. 1871. Aus dem thüringischen Schiefergebirge. Zeitschrift der Deutschen Geologischen Gesellschaft 23, 231-256.

RicKARDS, R.B. 1974. A new monograptid genus and the origin of the main monograptid genera. Special Papers in Palaeontology 13, 141-147.

RickARDS, R.B. 1995. Crinitograptus, a new genus of Ludlow (Silurian) graptoloid. Journal of Paleontology 69(6), 1107-1111.

Rickards, R.B. \& Bulman, O.M.B. 1965. The development of Lasiograptus harknessi (Nicholson 1867). Palaeontology 8(2), 272-280.

RickARDS, R.B. \& ChAPMAN, A. 1991. Bendigonian graptolites 
(Hemichordata) of Victoria. Memoirs of the Museum of Victoria 52(1), 1-135.

RickARDS, R.B. \& DURMAN, P.N. 2006. Evolution of the earliest graptolites and other hemichordates, 5-92. In BASSETT, M.G. \& Deisler, V.K. (eds) Studies in Palaeozoic Palaeontology. Geological Series 25. National Museum of Wales, Cardiff.

Rickards, R.B., Hutt, J.E. \& Berry, W.B.N. 1977. Evolution of the Silurian and Devonian graptoloids. Bulletin of the British Museum (Natural History), Geology Series 28, $1-120$.

RickARDS, R.B. \& JeLL, J.S. 2002. New graptolite faunas from the Llandovery, lower Silurian of the Graveyard Creek Subprovince, Broken River region, Queensland, Australia. Proceedings of the Geologists' Association 113, 111-120.

Rickards, R.B., Packham, G.H., Wright, A.J. \& Williamson, P.L. 1995. Wenlock and Ludlow graptolite faunas and biostratigraphy of the Quarry Creek district, New South Wales. Association of Australasian Paleontologists, Memoir 17, $1-68$.

Rickards, R.B. \& Wright, A.J. 1997. Graptolites of the Barnby Hills Shale (Silurian, Ludlow) New South Wales, Australia. Proceedings of the Yorkshire Geological Society 51(3), 209-227. DOI 10.1144/pygs.51.3.209

Rickards, R.B. \& Wright, A.J. 1999. Evolution of the Ludlow (Silurian) graptolite genus Bohemograptus Přibyl, 1936. Proceedings of the Yorkshire Geological Society 52(3), 313-320. DOI 10.1144/pygs.52.3.313

RickARDS, R.B. \& Wright, A.J. 2004. Enigmagraptus n. gen., a new graptoloid (Pridoli, Silurian, New South Wales, Australia). Paläontologische Zeitschrift 78(1), 189-194. DOI 10.1007/BF03009138

Ridewood, W.G. 1906. A new species of Cephalodiscus (C. gilchristi) from the Cape Seas. Marine Investigations in South Africa 4, 173-192.

RigBy, J. 1986. A critique of graptolite classification, and a revision of the suborders Diplograptina and Monograptina. Geological Society Special Publication 20, 1-12.

Riva, J.F. 1987. The graptolite Amplexograptus praetypicalis n. sp. and the origin of the typicalis group. Canadian Journal of Earth Sciences 24(5), 924-933. DOI 10.1139/e87-090

RivA, J.F. 1988. Graptolites at and below the Ordovician-Silurian boundary on Anticosti Island, Canada. Bulletin of the British Museum (Natural History) Geology 43, 221-237.

Riva, J.F. 1992. The pendent sigmagraptine graptoloid Keblograptus bidens (Keble). Alcheringa 16, 315-319. DOI 10.1080/03115519208619112

RivA, J.F. 1994. Yutagraptus mantuanus Riva in Rickards 1994, a pendent xiphograptid from the Lower Ordovician of Utah, USA, 1-13. In Chen, X., ERdtmann, B.-D. \& Ni, Y.N. (eds) Graptolite research today. 262 pp. Nanjing University Press, Nanjing.

Riva, J.F. \& KetneR, K.B. 1989. Ordovician graptolites from the northern Sierra de Cobachi, Sonora, Mexico. Transactions of the Royal Society of Edinburgh, Earth Sciences 80, 71-90. DOI 10.1017/S0263593300014401

Roselt, G. 1962. Über die ältesten Landpflanzen und eine mögliche Landpflanze aus dem Ludlow Sachsens. Geologie 2, 320-333.

Ross, R.B. \& BERRY, W.B.N. 1963. Ordovician graptolites of the Basin Ranges in California, Nevada, Utah and Idaho. U.S. Geological Survey Bulletin 1134, 1-177.

Ruedemann, R. 1895. Development and mode of growth of Diplograptus, McCoy. Fortieth Annual report of the New York State Geologist for the year 1894, 219-248.

Ruedemann, R. 1904. Graptolites of New York, Part 1. Graptolites of the Lower beds. New York State Museum Memoir 7, $1-803$.

Ruedemann, R. 1908. Graptolites of New York, Part 2. New York State Museum Memoir 11, 1-583.

Ruedemann, R. 1916. Paleontologic contributions from the New York State Museum. New York State Museum Bulletin 189, 7-97.

Ruedemann, R. 1925. Some Silurian (Ontarian) faunas of New York. New York State Museum Bulletin 265, 1-134.

Ruedemann, R. 1933. The Cambrian of the Upper Mississippi Valley, Part III. Graptoloidea. Bulletin of the Public Museum of the City of Milwaukee 12(3), 307-348.

Ruedemann, R. 1936. Ordovician graptolites from Quebec and Tennessee. Journal of Paleontology 10(5), 385-387.

RuedemanN, R. 1937. A new North American graptolite faunule. American Journal of Science 233, 57-62.

DOI 10.2475/ajs.s5-33.193.57

Ruedemann, R. 1947. Graptolites of North America. Geological Society of America Memoir, 19, 1-652.

DOI 10.1130/MEM19-p1

RUSCONI, C. 1948. Notas sobre fósiles ordovícicos y triásicos de Mendoza. Revista del Museo de Historia Natural de Mendoza 2, 245-254.

SAdler, P.M., CoOper, R.A. \& Melchin, M.J. 2011. Sequencing the graptoloid clade: building a global diversity curve from local range charts, regional composites and global time-scale. Proceedings of the Yorkshire Geological Society 58(4), 329-343. DOI 10.1144/pygs.58.4.296

SAlter, J.W. 1858. On Graptopora, a new genus of Polyzoa alied to graptolites. Proceedings of the American Association of the Advancement of Science 11, 63-66.

SAlter, J.W. 1862. On Peltocaris, a new genus of Silurian Crustacea. Quarterly Journal of the Geological Society of London 18 (1-2), 347.

DOI 10.1144/GSL.JGS.1862.018.01-02.48

SALTER, J.W. 1863. Notes on the Skiddaw Slate Fossils. Quarterly Journal of the Geological Society of London 19, 135-140.

SARS, G.O. 1872. On some remarkable forms of animal life from the great deeps off the Norwegian coast I. Partly from posthumous manuscripts of the late Professor Dr. Michael Sars. University Programm for the $1^{\text {st }}$ half-year $1869.82 \mathrm{pp}$. Brogger and Bristiff, Christiania.

SARS, G.O. 1874. On Rhabdopleura mirabilis (M. Sars). Quarterly Journal of Microscopical Science, New Series 14, 23-44.

SARS, M. 1868. Fortsatte Bemærkninger over det dyriske livs udbredning i havets dybder. Scerskilt aftryt af Videnskabersselskap forhandlinger for 1868, 245-275. 
SAto, T. 1936. Vorläufige Mitteilung über Atubaria heterolopha gen. nov. sp. nov., einen in freiem Zustand aufgefundenen Pterobranchier aus dem Stillen Ozean. Zoologischer Anzeiger 115, 97-106.

Schмid, W. 1939. Ein dendroider Graptolith aus dem Untersilur Thüringens. Beiträge zur Geologie von Thüringen 5(3), 121-126.

Schrank, F. von PaUla 1802. Fauna Boica. Durchdachte Geschichte der in Baiern einheimischen und zahmen Thiere. Zweyter Band, Zweyte Abtheilung. 412 pp. Johann Wilhelm Krüll, Ingolstadt.

SDZUY, K. 1974. Mittelkambrische Graptolithen aus NW-Spanien. Paläontologische Zeitschrift 48(1-2), 110-139. DOI 10.1007/BF02986992

Sedgwick, A. \& McCoy, F. [M'Coy, F.] 1855. Synopsis of the Classification of the British Palaeozoic Rocks (by the Rev. Adam Sedgwick, M.A. F.R.S.) with a systematic description of the British Palaeozoic Fossils in the Geological Museum of the University of Cambridge (by Frederick McCoy, F.G.S. Hon. F.C.P.S.). I-XCVIII + 661 pp. John W. Parker \& Son, West Strand; Deighton, Bell \& Co. \& MacMillan \& Co, Cambridge. [2 volumes; I: text; II: plates; originally published in 3 instalments, 1851, 1852, 1854]

SeIlacher, A. \& SeIlacher, E. 1994. Bivalvian trace fossils: a lesson from actuopaleontology. Courier Forschung Senckenberg 169, 5-15.

SenNikov, N.V. 1976. Graptolity i stratigrafiya nizhnego silura Altaya [Graptolites and stratigraphy of the Lower Silurian of the Altai]. Trudy Instituta geologii i geofiziki, Akademiya nauk SSSR, Sibirskoe otdelenie 304, 1-230. [in Russian]

SenNikov, N.V. 1984. Nekotorye retiolitidy (graptolity) gornogo Altaya [Some retiolitids (graptolites) of the Altai Mountains]. Trudy Instituta geologii i geofiziki, Akademiya nauk SSSR, Sibirskoe otdelenie 584, 48-55. [in Russian]

SenNikov, N.V. 1998. New graptolite taxa from the Middle Cambrian to Ordovician of central Siberia. News of Paleontology and Stratigraphy. Supplement to journal Geologiya i geofizika 1, 15-32. [in Russian]

SEPKowSKI, JR., J.J. 1979. A kinetic model of Phanerozoic taxonomic diversity II. Early Phanerozoic families and multiple equilibria. Paleobiology 5(3), 222-251.

SHERwIN, L. \& RicKARDS, R.B. 2000. Rogercooperia, a new genus of Ordovician glossograptid graptolites from southern Scotland and New South Wales, Australia. Scottish Journal of Geology 36, 159-164. DOI 10.1144/sjg36020159

Skevington, D. 1963. Graptolites from the Ontikan Limestones (Ordovican) of Öland, Sweden. I: Dendroidea, Tuboidea, Camaroidea, and Stolonoidea. The Bulletin of the Geological Institutions of the University of Uppsala 42, 1-62.

Skevington, D. 1965. Graptolites from the Ontikan Limestones (Ordovician) of Öland, Sweden. II: Graptoloidea and Graptovermida. Publications from the Palaeontological Institution of the University of Uppsala 63, 1-73.

Skoglund, R. 1961. Kinnegraptus, a new graptolite genus from the Lower Didymograptus Shale of Västergötland, central Sweden. Bulletin of the Geological Institute of the University of Uppsala 40, 389-400.
Skwarko, S.K. 1968. Some Ordovician graptolites from the Canning Basin, western Australia. 1. On the structure of Didymograptus artus Elles and Wood. Bulletin of the Bureau of Mineral Resources, Geology and Geophysics of Australia 92, 171-190.

Skwarko, S.K. 1974. Some graptolites from the Canning Basin, western Australia 2. Graptolites from the Goldwyer No. 1 well. Bulletin of the Bureau of Mineral Resources, Geology and Geophysics of Australia 150, 43-56.

Snelling, A.M. \& Zalasiewicz, J.A. 2011. The evolutionary lineage of Petalolithus to Cephalograptus: evidence from Coalpit Bay, Northern Ireland. Proceedings of the Yorkshire Geological Society 58, 345-350. DOI 10.1144/pygs.58.4.305

Sosef, M.S.M. 1997. Hierarchical models, reticulate evolution and the inevitability of paraphyletic supraspecific taxa. Taxon 46(1), 75-85. DOI $10.2307 / 1224293$

SPENCER, J.W. 1878. Graptolites from the Niagara Formation. $\mathrm{Ca}$ nadian Naturalist and Geologist 8, 457-463.

SPENCER, J.W. 1883. Occurrence of graptolites in the Niagara Formation of Canada. Proceedings of the American Association for the Advancement of Science 31, 363-365.

Spengel, J.W. 1932. Planctosphaera. Report on the scientific results of the "Michael Sars" North Atlantic Deep-Sea Expedition 1910, Vol. 5, 590-600.

SpJeldnaes, N. 1963. Some Upper Tremadocian graptolites from Norway. Palaeontology 6(1), 121-131.

Steiner, M. \& Maletz, J. 2012. Cambrian graptolites (Pterobranchia) and the origin of colonial organization in metazoans. Terra Nostra 3, 173-174.

Stewart, S. \& Mitchell, C.E. 1997. Anticostia, a distinctive new Late Ordovician "glyptograptid" (Diplograptacea, Graptoloidea) based on three-dimensionally preserved specimens from Anticosti Island, Quebec. Canadian Journal of Earth Sciences 34(2), 215-228. DOI 10.1139/e17-018

ŠтоRCH, P. 1998a. New data on Telychian (Upper Llandovery, Silurian) graptolites from Spain. Journal of the Czech Geological Society 43, 113-142.

S̆тоRсн, P. 1998b. Graptolites of the Pribylograptus leptotheca and Lituigraptus convolutus biozones of Tmaň (Silurian, Czech Republic). Journal of the Czech Geological Society 43(3), 209-272.

Štorch, P., Mitchell, C.E., Finney, S.C. \& Melchin, M.J. 2011. Uppermost Ordovician (upper Katian - Hirnantian) graptolites of north-central Nevada, U.S.A. Bulletin of Geosciences 86(2), 301-386. DOI 10.3140/bull.geosci.1264

ŠTorch, P. \& Serpagli, E. 1993. Lower Silurian graptolites from Southwestern Sardinia. Bollettino della Società Paleontologica Italiana 32, 3-57.

Strachan, I. 1954. The structure and development of Peiragraptus fallax, gen. et sp. nov. A new graptolite from the Ordovician of Canada. Geological Magazine 41(6), 509-513. DOI 10.1017/S0016756800066334

Strachan, I. 1985. The significance of the proximal end of Cryptograptus tricornis (Carruthers) (Graptolithina). Geological Magazine 122(2), 151-155.

DOI 10.1017/S0016756800031058

StRACHAN, I. 1990. A new genus of abrograptid graptolite from 
the Ordovician of Southern Scotland. Palaeontology 33(4), 933-936.

SudBuRY, M. 1958. Triangulate monograptids from the Monograptus gregarius zone (Lower Llandovery) of the Rheidol Gorge (Cardiganshire). Philosophical Transactions of the Royal Society of London, Series B 241(685), 485-554. DOI 10.1098/rstb.1958.0011

SuEss, E. 1851. Über böhmische Graptolithen. Naturwissenschaftliche Abhandlungen von W. Haidinger 4(4), 87-134.

Swalla, B.J. \& Smith, A.B. 2008. Deciphering deuterostome phylogeny: molecular, morphological and palaeontological perspectives. Philosophical Transactions of the Royal Society B 363, 1557-1568. DOI 10.1098/rstb.2007.2246

Termier, H. \& Termier, G. 1948. Les graptolithes dendroides en Afrique du nord. Compte rendu sommaire des séances de la Société géologique de France 9, 174-176.

ThомAs, D.E. 1972. Two new graptolites from Victoria, Australia. Geological Magazine 109(6), 529-532. DOI 10.1017/S0016756800042801

Tinn, O., Meidla, T., Ainsaar, L. \& Pani, T. 2009. Thallophytic algal flora from a new Silurian Lagerstätte. Estonian Journal of Earth Sciences 58, 38-42. DOI 10.3176/earth.2009.1.04

TÖRNQUIST, S.L. 1865. Om Fågelsångstraktens Undersiluriska lager. Geologiska Iakttagelser. Lunds Universitets årsskrift 1, $1-24$.

TöRnQUIST, S.L. 1901. Researches into the graptolites of the lower zones of the Scanian and Vestrogothian Phyllo-Tetragraptus beds, Part 1. Lunds Universitets årsskrift 37(2), 1-26.

TöRnQuIST, S.V. 1904. Researches into the Graptolites of the Lower Zones of the Scanian and Vestrogothian Phyllo-Tetragraptus beds 2. Lunds Universitets årsskrift 40, Afdeln. 2(2), 1-29.

TsEgelniuk, P.D. 1976. Late Silurian and early Devonian monograptids from the south-western margin of the East European Platform, 91-133. In SHUlga, P.L. (ed.) Palaeontology and Stratigraphy of the Upper Precambrian and Lower Paleozoic of the South-West part of the east European Platform. Naukova dumka, Kiev. [in Russian]

TsegelniuK, P.D. 1998. Problems in the evolution of the Silurian Uncinatograptinae and their stratigraphic value. Temas Geologico-Mineros ITGE 23, 271-273.

TullBerg, S.A. 1880. Tvenne nya graptolitslägten. Geologiska Föreningens i Stockholm Förhandlingar 5(7), 313-316. DOI 10.1080/11035898009443937

TULLBERG, S.A. 1883. Skånes Graptoliter II. Graptolitfaunorna I Cardiolaskiffern och Cyrtograptusskiffern. Sveriges Geologiska Undersökning, Serie C, Afhandlingar och Upsatser 55, $1-43$.

Tzaj, D.T. (Tsay, D.T.) 1969. A new Ordovician genus Acrograptus. Paleontological Journal 1, 133-134.

TzaJ, D.T. (Tsay, D.T.) 1973. Novyy ordovikskiy rod Kstaugraptus Tzaj gen. nov. Trudy Instituta geologii $i$ geofiziki (Novosibirsk) 47, 5-6. [in Russian]

URBAneK, A. 1954. Some observations on the morphology of Monograptidae. Acta Geologica Polonica 4, 291-306.

UrbaneK, A. 1958. Monograptidae from erratic boulders of Poland. Acta Palaeontologica Polonica 9, 1-105.

URBANEK, A. 1963. On generation and regeneration of cladia in some Upper Silurian monograptids. Acta Palaeontologica Polonica 8(2), 135-254.

URBANEK, A. 1966. On the morphology and evolution of the Cucullograptinae (Monograptidae, Graptolithina). Acta Palaeontologica Polonica 11(3/4), 291-544.

UrbaneK, A. 1970. Neocucullograptinae n. subfam. (Graptolithina) - their evolutionary and stratigraphic bearing. Acta Palaeontologica Polonica 15(2/3), 163-388.

URBANEK, A. 1986. The enigma of graptolite ancestry: lesson from a phylogenetic debate, 184-226. In Hoffman, A. \& Nitecki, M. (eds) Enigmatic Fossil Taxa. Oxford University Press, Oxford.

UrbaneK, A. 1997. Late Ludfordian and arly Pridoli monograptids from the Polish lowland. Palaeontologia Polonica $56,87-231$.

Urbanek, A., Radzevičius, S., KozŁowska, A. \& Teller, L. 2012. Phyletic evolution and iterative speciation in the persistent Pristiograptus dubius lineage. Acta Palaeontologica Polonica 57(3), 589-611. DOI 10.4202/app.2010.0070

VAN Phuc, N. 1998. Vietnamograptus: a new diplograptid genus from the Monograptus hercynicus zone of the Muongxen area, northwest part of Central Vietnam. Temas Geológico-Mineros $23,286$.

WalcotT, C.D. 1919. Middle Cambrian algae. Smithsonian Miscellaneous collections 67(5), 217-260.

WANG, X.F. 1977. The discovery of the latest Silurian and early Devonian monograptids from Qinzhou, Guangxi, and its significance. Acta Geologica Sinica 1977, 190-205.

WANG, X.F., Jin, Y.Q., Wu, Z.T., Fu, H.Y., Li, Z.C. \& MA, G.G. (eds) 1977. Graptolites of Central-South China. In Handbook to Palaeontology of central-south China. Pt 1. Early Palaeozoic Era. Geological Publishing House, Beijing. [in Chinese]

WANG, X.F. \& WANG, C. 2001. Tremadocian (Ordovician) graptolite diversification events in China. Alcheringa 25(2), 155-168. DOI 10.1080/03115510108619102

Westergåd, A.H. 1909. Studier öfver Dictyograptus-skiffern och dess Gränslager Meddelingens om Lunds Geologiska Fältsklubb, Series B4, 1-98.

WHITFIELD, R.P. 1902. Notice of a new genus of marine algæ, fossil in the Niagara Shale. American Museum of Natural History, Bulletin 16, 399-400.

Whittington, H.B. 1954. A new Ordovician graptolite from Oklahoma. Journal of Paleontology 28(5), 613-621.

Whittington, H.B. 1955. Additional new Ordovician graptolites and a chitinozoan from Oklahoma. Journal of Paleontology 29(5), 837-851.

WiLLIAMs, S.H. 1992. Lower Ordovician (Arenig-Llanvirn) graptolites from the Notre Dame Subzone, central Newfoundland. Canadian Journal of Earth Sciences 29(8), 1717-1733. DOI 10.1139/e92-135

Williams, S.H. \& Stevens, R.K. 1988. Early Ordovician (Arenig) graptolites of the Cow Head Group, western Newfoundland, Canada. Palaeontographica Canadiana 5, 1-167.

Williams, S.H. \& Stevens, R.K. 1991. Late Tremadoc graptolites from western Newfoundland. Palaeontology 34 (1), $1-47$.

Wiman, C. 1901. Über die Borkholmer Schicht im Mittel- 
baltischen Silurgebiet. Bulletin of the Geological Institutions of the University of Uppsala 5, 151-222.

Winchell, C.J., Sullivan, J., Cameron, C.B. Swalla, B.J. \& Mallatt, J. 2002. Evaluating hypotheses of deuterostome phylogeny and chordate evolution with new LSU and SSU ribosomal DNA data. Molecular Biology and Evolution 19(5), 762-776. DOI 10.1093/oxfordjournals.molbev.a004134

Worsaae, K., Sterrer, W., Kaul-Strehlow, S., Hay-Schmidt, A. \& GiRIBET, G. 2012. An anatomical description of a miniaturized acron worm (Hemichordata, Enteropneusta) with asexual reproduction by paratomy. PLOS One 7(11), 1-19. DOI 10.1371/journal.pone.0048529

Xiao, C.X. \& Chen, H. 1990. Some graptolite faunas of the Lower and Middle Ordovician from Gucheng area, Yushan. Geology of Jiangxi 4(2), 83-243.

XiaO, C.X., XiA, T.L. \& Wang, Z.Y. 1985. New materials of Cardiograptidae from S. Jiangxi and their evolutionary relationship. Acta Palaeontologica Sinica 24(4), 429-439.

Yakovleva, N.N. (Yakovlev, N.N.) 1933. Planktonyi graptolit iz Kazakhstana [A planktonic graptolite from Kazakhstan]. Izvestia Akademii nauk SSSR, Otdelenie matematicheskikh i estestvennykh nauk, 979-981. [in Russian]

YANG, D.Q., Ni, Y.N., Li, J.J., Chen, X., Lin, Y.K., Yu, J.H., XIA, G.S., JiAO, S.D., FANG, Y.T., Ge, M.Y. \& Mu, E.Z. 1983. Hemichordata, 353-508. In NANuing Institute of GeOlogy and Mineral Resources (ed.) Palaeontological Atlas of East China. Geological Publishing House, Beijing.

YIN, T.H. 1937. Brief description of the Ordovician and Silurian fossils from Shihtien. Bulletin of the Geological Society of China 16, 281-302.

DOI 10.1111/j.1755-6724.1937.mp16001012.x

Yu, J.H. 1962. Graptolites (Ptilograptidae) from West Yunnan. Bulletin of Nanjing University (Geology) 2, 47-54.
YU, J.H. \& FANG, Y.T. 1966. The discovery of graptolites with folded thecae from the Hulo Shale of the Xiushui (Siushui) drainage basin, Jiangxi (Kiangsi). Acta Palaeontologica Sinica 14(1), 92-97.

YU, J.H. \& FANG, Y.T. 1979. On the classification of graptoloids. Acta Palaeontologica Sinica 18(5), 435-443.

YU, J.H. \& FANG, Y.T. 1981. Arienigraptus, a new genus from the Ningkuo Formation (Lower Ordovician) of south China. Acta Palaeontologica Sinica 20, 27-32.

Zalasiewicz, J. \& Howe, M.P.A. 2003. A case of profound astogenetic metamorphosis: the structure and affinities of Awarograptus nodifer (Törnquist, 1881). Scottish Journal of Geology 39(1), 45-49. DOI 10.1144/sjg39010045

ZANDER, R.H. 2007. Paraphyly and the species concept, a reply to Ebach et al. Taxon 56(3), 642-644. DOI $10.2307 / 25065848$

Zessin, W. \& PuttKamer, K., Freiherr von 1994. Melanostrophus fokini Öpik (Graptolithina, Stolonoidea) - Fund einer vollständigen Kolonie in einem ordovizischen Geschiebe von Rendsburg, Schleswig-Holstein. Archiv für Geschiebekunde 1(10), 563-572.

Zhaо, X. \& Zhang, S. 1985. Reclined graptolites of the Xinchangian. Journal of Changchun College of Geology 2(40), 13-26.

ZhaO, Y.T. 1964. A new multiramous graptolite from Ningkuo Shale of Zhejiang. Acta Palaeontologica Sinica 12(4), 638-641.

ZHAO, Y.T. 1984. A new genus - Sichuanograptus gen. nov. from the Lower Silurian of Nanjiang. Sichuan Province. Professional papers in Stratigraphy and Palaeontology 11, 97.

ZHAO, Y.T. 1984. On the evolution of monograptids based on the contraction of the thecal apertural margin. Acta Geologica Sinica 58(2), 97-105. [in Chinese with English abstract] 